Prepared in cooperation with the Lewis and Clark, Lower Elkhorn, Lower Loup, Lower Platte North, Lower Niobrara, Middle Niobrara, Upper Elkhorn, and Upper Loup Natural Resources Districts

\title{
Simulation of Groundwater Flow and Effects of Groundwater Irrigation on Stream Base Flow in the Elkhorn and Loup River Basins, Nebraska, 1895-2055-Phase Two
}

Scientific Investigations Report 2010-5149 
Cover. Three-dimensional shaded relief of streams draining the Elkhorn and Loup River Basins, Nebraska. 


\section{Simulation of Groundwater Flow and Effects of Groundwater Irrigation on Stream Base Flow in the Elkhorn and Loup River Basins, Nebraska, 1895-2055-Phase Two}

By Jennifer S. Stanton, Steven M. Peterson, and Michael N. Fienen

Prepared in cooperation with the Lewis and Clark, Lower Elkhorn, Lower Loup, Lower Platte North, Lower Niobrara, Middle Niobrara, Upper Elkhorn, and Upper Loup Natural Resources Districts

Scientific Investigations Report 2010-5149 


\title{
U.S. Department of the Interior \\ KEN SALAZAR, Secretary \\ U.S. Geological Survey \\ Marcia K. McNutt, Director
}

\section{U.S. Geological Survey, Reston, Virginia: 2010}

\author{
For more information on the USGS — the Federal source for science about the Earth, its natural and living resources, \\ natural hazards, and the environment, visit http://www.usgs.gov or call 1-888-ASK-USGS \\ For an overview of USGS information products, including maps, imagery, and publications, \\ visit http://www.usgs.gov/pubprod \\ To order this and other USGS information products, visit http://store.usgs.gov
}

\begin{abstract}
Any use of trade, product, or firm names is for descriptive purposes only and does not imply endorsement by the U.S. Government.

Although this report is in the public domain, permission must be secured from the individual copyright owners to reproduce any copyrighted materials contained within this report.
\end{abstract}

Suggested citation:

Stanton, J.S., Peterson, S.M., Fienen, M.N., 2010, Simulation of groundwater flow and effects of groundwater irrigation on stream base flow in the Elkhorn and Loup River Basins, Nebraska, 1895-2055—Phase Two: U.S. Geological Survey Scientific Investigations Report 2010-5149, 78 p. with app. 


\section{Acknowledgments}

The authors thank the members of the Elkhorn-Loup Model (ELM) technical committee for providing personal knowledge about the ELM study area, assistance with data-collection efforts, and guidance during simulation development: Tylr Naprstek, Russ Callan, and Butch Koehlmoos of the Lower Loup Natural Resources District (NRD); Dennis Schueth and Tom Riley of the Upper Elkhorn NRD; Rick Wozniak and Stan Staab of the Lower Elkhorn NRD; Curt Becker and Larry Angle of the Lower Platte North NRD; Mike Murphy and Reed Welke of the Middle Niobrara NRD; Jim Schneider and Jesse Bradley of the Nebraska Department of Natural Resources; and Sue Lackey of the Conservation and Survey Division, University of Nebraska-Lincoln. Staff from the Upper Loup and Lower Niobrara NRDs provided assistance with data-collection efforts. Appreciation is extended to Rich Kern of the Nebraska Department of Natural Resources for providing land-use data. The authors also thank Paul Barlow of the U.S. Geological Survey (USGS) Office of Groundwater for providing support for the Groundwater-Management Process for MODFLOW. Stan Leake and Bruce Campbell of the USGS provided constructive reviews of earlier versions of this report. This study was made possible by support provided by the Nebraska Natural Resources Commission and the ELM NRDs. 



\section{Contents}

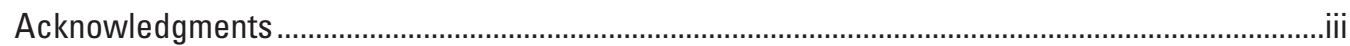

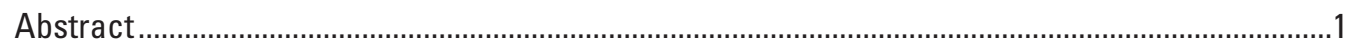

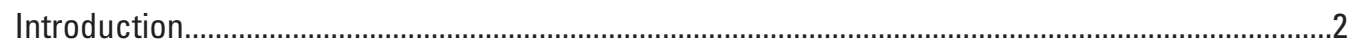

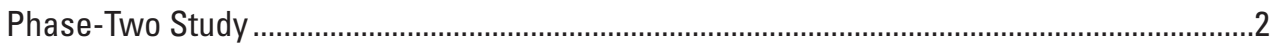

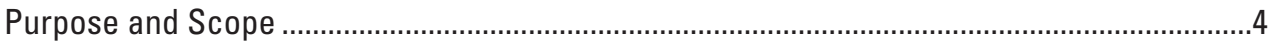

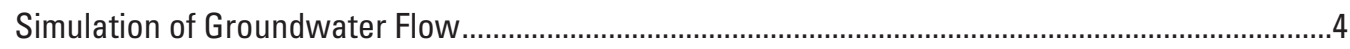

Spatial and Temporal Discretization...............................................................................

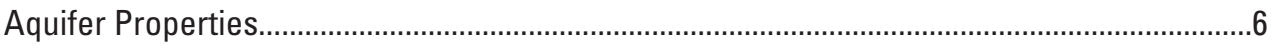

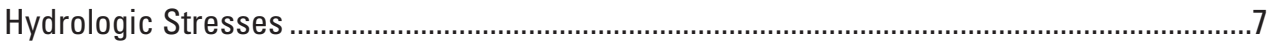

Flow Across Lateral Boundaries ..................................................................................

Streambed Seepage ...................................................................................................

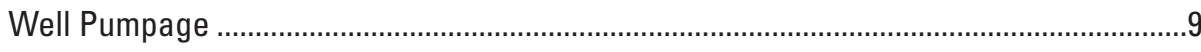

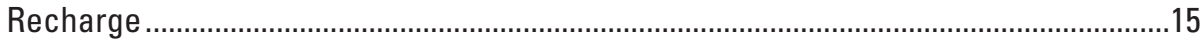

Recharge from Precipitation............................................................................15

Additional Recharge Beneath Agricultural Land ....................................................18

Additional Recharge from Canal Seepage ..........................................................18

Comparison with Watershed Model Recharge ......................................................20

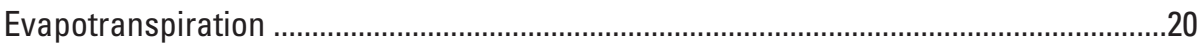

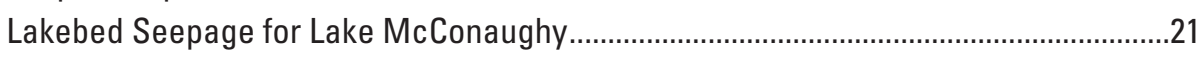

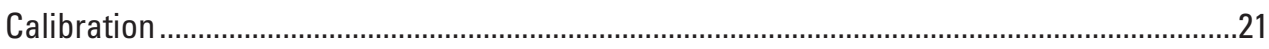

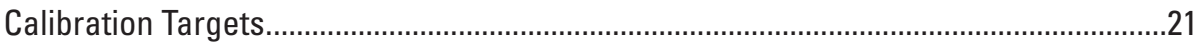

Groundwater-Level Targets Used During the Pre-1940 Period ................................21

Groundwater-Level-Change Targets Used During the 1940 through 2005

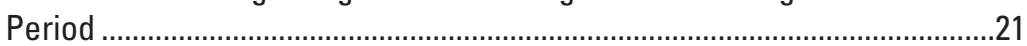

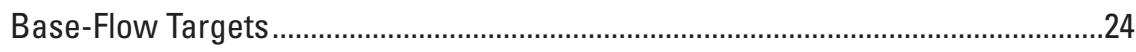

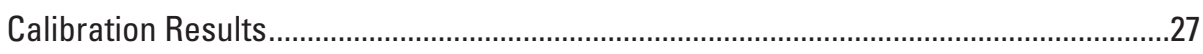

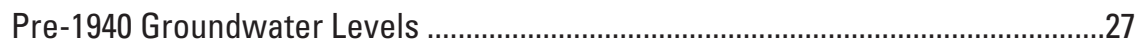

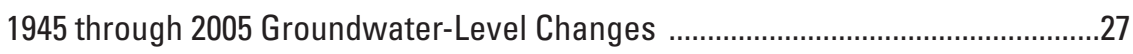

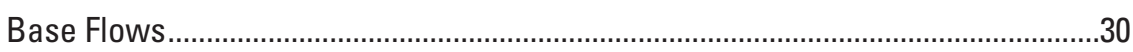

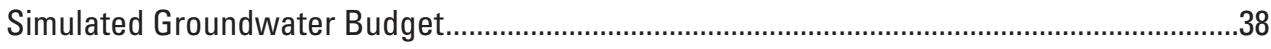

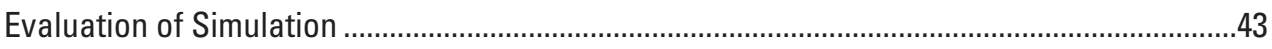

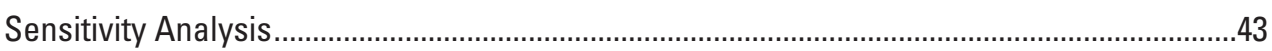

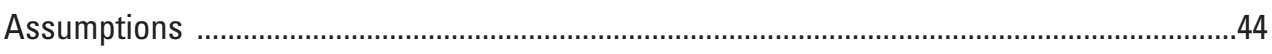

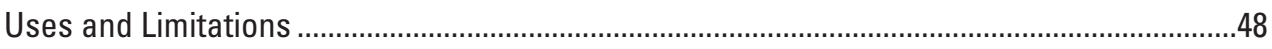

Simulation of Effects of Groundwater Irrigation on Stream Base Flow ........................................48

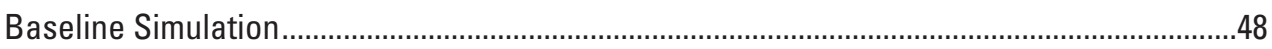

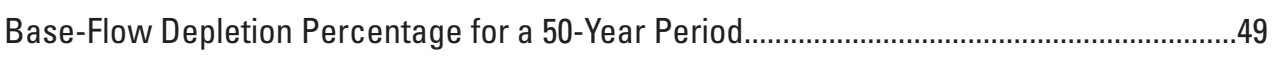

Effect on Base Flow of Decreasing or Increasing Irrigated Acres .........................................56

Effect of Decreased Irrigated Acres ………………….............................................56

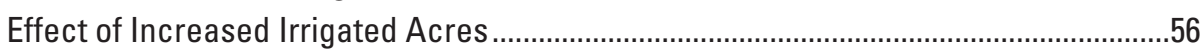

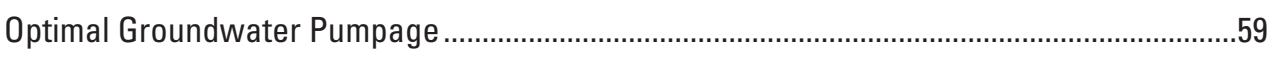

Simulation-Optimization Model .....................................................................................5 
Results of the Simulation-Optimization Model................................................................62

Scenario 1: Base-Flow Requirement Specified for Elkhorn River at Norfolk .........62

Scenario 2: Base-Flow Requirement Specified for Elkhorn River at Norfolk and at Confluence with North Fork Elkhorn River........................................62

Scenario 3: Optimal Pumpage for Supporting In-Stream Flow Appropriation A-17331 ..........................................................................63

Estimating Base-Flow Requirement for Appropriation A-17331 .....................64

Optimal Pumpage for Supporting Appropriation A-17331 ……....................64

Summary and Conclusions....................................................................................................65

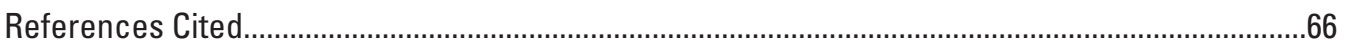

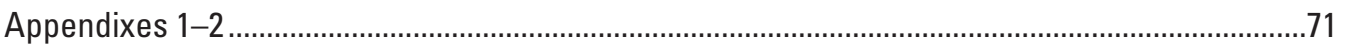

Appendix 1. Comparison of phase-one and phase-two groundwater-flow simulations,

Elkhorn and Loup River Basins, Nebraska .....................................................................72

Appendix 2. Automated Calibration Using Parameter Estimation Software....................................74

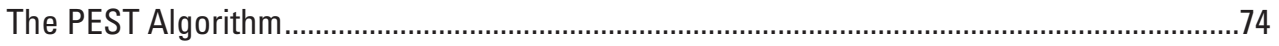

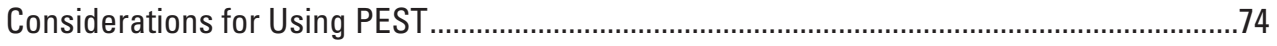

Advantages to Using PEST in Comparison to Trial and Error ........................................75

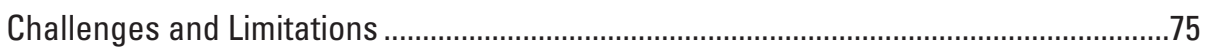

Use of PEST for the Elkhorn-Loup Model ........................................................................76

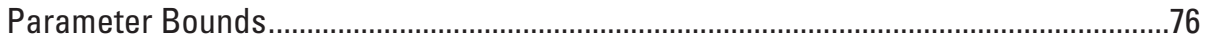

Prior Information through Regularization ....................................................................

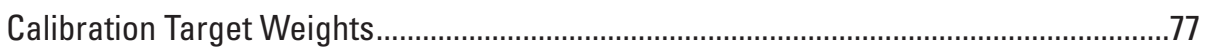

\section{Figures}

1. Map showing location of the Elkhorn-Loup Model study area, Elkhorn and Loup

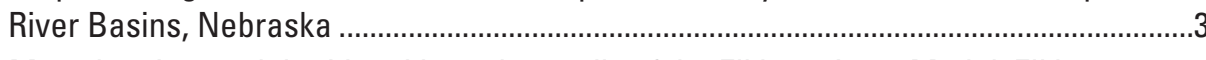

2. Map showing model grid and boundary cells of the Elkhorn-Loup Model, Elkhorn and Loup River Basins, Nebraska ..................................................................................

3. Map showing calibrated hydraulic conductivity, Elkhorn and Loup River Basins, Nebraska

4. Map showing calibrated streambed hydraulic conductivity, Elkhorn and Loup River Basins, Nebraska.

5. Graph showing yearly estimates of acres of cropland irrigated by groundwater and surface water, 1940 through 2005, Elkhorn and Loup River Basins, Nebraska

6. Maps showing average annual net irrigation pumpage by county, 1940 through 2005, Elkhorn and Loup River Basins, Nebraska

7. Map showing total simulated groundwater pumpage and estimated total groundwater use, by county, 2000, Elkhorn and Loup River Basins, Nebraska

8. Map showing calibrated recharge from precipitation, Elkhorn and Loup River Basins, Nebraska.

9. Map showing canal systems and irrigation districts in and near the Elkhorn and Loup River Basins, Nebraska.

10. Map showing calibrated maximum rate of evapotranspiration (ET) from groundwater, Elkhorn and Loup River Basins, Nebraska 
11. Map showing distribution of groundwater-level measurements and base-flow observations used to calibrate simulation of the pre-1940 period, Elkhorn and Loup River Basins, Nebraska...

12. Map showing distribution of groundwater-level-change measurements and base-flow observations used to calibrate the simulation for the 1940 through 2005 period, Elkhorn and Loup River Basins, Nebraska.

13. Map showing differences between measured and simulated groundwater levels, 1939, Elkhorn and Loup River Basins, Nebraska

14. Map showing simulated 1939 and previously published 1979 groundwater-levelelevation contours, Elkhorn and Loup River Basins, Nebraska...

15. Map showing measured and simulated groundwater-level change, 1945 to 1955, Elkhorn and Loup River Basins, Nebraska

16. Map showing measured and simulated groundwater-level change, 1955 to 1965, Elkhorn and Loup River Basins, Nebraska

17. Map showing measured and simulated groundwater-level change, 1965 to 1975 , Elkhorn and Loup River Basins, Nebraska

18. Map showing measured and simulated groundwater-level change, 1975 to 1985 , Elkhorn and Loup River Basins, Nebraska

19. Map showing measured and simulated groundwater-level change, 1985 to 1995 , Elkhorn and Loup River Basins, Nebraska

20. Map showing measured and simulated groundwater-level change, 1995 to 2005, Elkhorn and Loup River Basins, Nebraska

21. Graphs showing measured and simulated groundwater levels, 1940 through 2005, and number of irrigated acres per square mile, 2005, Elkhorn and Loup River Basins, Nebraska.

22. Graphs showing estimated and simulated annual base flow, 1940 through 2005 , Elkhorn and Loup River Basins, Nebraska

23. Map showing differences between estimated and simulated annual base flow, 2005, Elkhorn and Loup River Basins, Nebraska

24. Maps showing relative sensitivity of simulated 1939 groundwater levels to a 1-percent change in $A$, horizontal hydraulic conductivity and $B$, recharge from precipitation, Elkhorn and Loup River Basins, Nebraska.

25. Maps showing relative sensitivity of simulated groundwater-level changes throughout the 1940 through 2005 period to a 1-percent change in $A$, horizontal hydraulic conductivity and $B$, recharge from precipitation, Elkhorn and Loup River Basins, Nebraska.

26. Maps showing relative sensitivity of simulated 1940 through 2005 base flow to a 1-percent change in $A$, horizontal hydraulic conductivity and $B$, recharge from precipitation, Elkhorn and Loup River Basins, Nebraska

27. Maps showing average annual net irrigation pumpage by county, 2009 through 2055, Elkhorn and Loup River Basins, Nebraska

28. Map showing simulated base flow in 2055 from the baseline simulation, Elkhorn and Loup River Basins, Nebraska.

29. Graph showing sources of water to a pumping well as a function of time

30. Map showing percentage of hypothetical well pumpage corresponding to simulated base-flow depletion in the Elkhorn and Loup River Basins, for 2006 through 2055

31. Maps showing percentage of hypothetical well pumpage corresponding to simulated depletion of $A$, evapotranspiration from groundwater and $B$, groundwater storage in the Elkhorn and Loup River Basins, for 2006 through 2055.......55 
32. Map showing increase to simulated 2033 base flow caused by 10 percent reduction in irrigated acres within Lower Elkhorn, Lower Loup, Upper Elkhorn, and Upper Loup Natural Resources Districts, 2009 through 2033 simulation period ......57

33. Map showing decrease to simulated 2033 base flow caused by 25,000 -acre increase in irrigated acres within Lower Elkhorn, Lower Loup, Lower Platte North, Upper Elkhorn, and Upper Loup Natural Resources Districts, 2009 through 2033 simulation period

34. Graph showing simulated annual base flow, recharge, and pumpage within the Elkhorn River Basin, 1940 through 2055

35. Map showing management status of pumping wells included in simulationoptimization model, 2009 through 2033, Elkhorn and Loup River Basins, Nebraska........61

36. Graph showing optimal reduction in simulated pumpage necessary to meet hypothetical base-flow requirements in 2033 for Elkhorn River at Norfolk, Nebraska

37. Graph showing optimal reduction in simulated pumpage necessary to meet hypothetical base-flow requirements in $\mathbf{2 0 3 3}$ for Elkhorn River at Norfolk and at the confluence with North Fork Elkhorn River, Nebraska

\section{Tables}

1. Location of pumpage measurements, average measured pumpage, and adjustments made to crop irrigation requirement, Elkhorn and Loup River Basins, Nebraska.

2. Mean annual ratio of base flow to total streamflow for selected streamflowgaging stations, Elkhorn and Loup River Basins, Nebraska

3. Statistical summary of calibration to decadal groundwater-level-change targets, 1945-2005.

4. Difference between estimated and simulated annual base flow by stream size, 1940-2005, Elkhorn and Loup River Basins, Nebraska.

5. Difference between estimated and simulated annual base flow by streamflowgaging station, 1940-2005, Elkhorn and Loup River Basins, Nebraska.

6. Simulated groundwater budget by simulation period, Elkhorn and Loup River Basins, Nebraska.

7. Estimated and simulated base flow at selected streamflow-gaging stations, Elkhorn and Loup River Basins, Nebraska .. 


\section{Conversion Factors}

Inch/Pound to SI

\begin{tabular}{|c|c|c|}
\hline Multiply & By & To obtain \\
\hline \multicolumn{3}{|c|}{ Length } \\
\hline inch (in.) & 2.54 & centimeter $(\mathrm{cm})$ \\
\hline inch (in.) & 25.4 & millimeter $(\mathrm{mm})$ \\
\hline foot $(\mathrm{ft})$ & 0.3048 & meter $(\mathrm{m})$ \\
\hline mile (mi) & 1.609 & kilometer (km) \\
\hline \multicolumn{3}{|c|}{ Area } \\
\hline acre & 4,047 & square meter $\left(\mathrm{m}^{2}\right)$ \\
\hline acre & 0.004047 & square kilometer $\left(\mathrm{km}^{2}\right)$ \\
\hline square foot $\left(\mathrm{ft}^{2}\right)$ & 0.09290 & square meter $\left(\mathrm{m}^{2}\right)$ \\
\hline square mile $\left(\mathrm{mi}^{2}\right)$ & 2.590 & square kilometer $\left(\mathrm{km}^{2}\right)$ \\
\hline \multicolumn{3}{|c|}{ Volume } \\
\hline cubic foot $\left(\mathrm{ft}^{3}\right)$ & 0.02832 & cubic meter $\left(\mathrm{m}^{3}\right)$ \\
\hline acre-foot (acre-ft) & 1,233 & cubic meter $\left(\mathrm{m}^{3}\right)$ \\
\hline \multicolumn{3}{|c|}{ Flow rate } \\
\hline acre-foot per year (acre-ft/yr) & 1,233 & cubic meter per year $\left(\mathrm{m}^{3} / \mathrm{yr}\right)$ \\
\hline foot per day (ft/d) & 0.3048 & meter per day $(\mathrm{m} / \mathrm{d})$ \\
\hline cubic foot per second $\left(\mathrm{ft}^{3} / \mathrm{s}\right)$ & 0.02832 & cubic meter per second $\left(\mathrm{m}^{3} / \mathrm{s}\right)$ \\
\hline million gallons per day (Mgal/d) & 0.04381 & cubic meter per second $\left(\mathrm{m}^{3} / \mathrm{s}\right)$ \\
\hline \multicolumn{3}{|c|}{ Crop water usage per unit area; Recharge, Evaporation, Evapotranspiration } \\
\hline inch per year (in/yr) & 25.4 & millimeter per year $(\mathrm{mm} / \mathrm{yr})$ \\
\hline acre-inch per acre (acre-in/acre) & 25.4 & millimeter $(\mathrm{mm})$ \\
\hline \multicolumn{3}{|c|}{ Hydraulic conductivity } \\
\hline foot per day $(\mathrm{ft} / \mathrm{d})$ & 0.3048 & meter per day $(\mathrm{m} / \mathrm{d})$ \\
\hline \multicolumn{3}{|c|}{ Transmissivity* } \\
\hline foot squared per day $\left(\mathrm{ft}^{2} / \mathrm{d}\right)$ & 0.09290 & meter squared per day $\left(\mathrm{m}^{2} / \mathrm{d}\right)$ \\
\hline \multicolumn{3}{|c|}{ Specific storage } \\
\hline per foot $\left(\mathrm{ft}^{-1}\right)$ & 0.3048 & per meter $\left(\mathrm{m}^{-1}\right)$ \\
\hline
\end{tabular}

Vertical coordinate information is referenced to the North American Geodetic Vertical Datum of 1929 (NGVD 29).

Horizontal coordinate information is referenced to the North American Datum of 1983 (NAD 83).

Altitude, as used in this report, refers to distance above the vertical datum.

*Transmissivity: The standard unit for transmissivity is cubic foot per day per square foot times foot of aquifer thickness [( $\left.\left.\mathrm{ft}^{3} / \mathrm{d}\right) / \mathrm{ft}^{2}\right] \mathrm{ft}$. In this report, the mathematically reduced form, foot squared per day $\left(\mathrm{ft}^{2} / \mathrm{d}\right)$, is used for convenience. 



\title{
Simulation of Groundwater Flow and Effects of Groundwater Irrigation on Stream Base Flow in the Elkhorn and Loup River Basins, Nebraska, 1895-2055- Phase Two
}

\author{
By Jennifer S. Stanton, Steven M. Peterson, and Michael N. Fienen
}

\section{Abstract}

Regional groundwater-flow simulations for a 30,000-square-mile area of the High Plains aquifer, referred to collectively as the Elkhorn-Loup Model, were developed to predict the effects of groundwater irrigation on stream base flow in the Elkhorn and Loup River Basins, Nebraska. Simulations described the stream-aquifer system from predevelopment through 2005 [including predevelopment (pre-1895), early development (1895-1940), and historical development (1940 through 2005) conditions] and future hypothetical development conditions (2006 through 2033 or 2055). Predicted changes to stream base flow that resulted from simulated changes to groundwater irrigation will aid development of long-term strategies for management of hydrologically connected water supplies.

The predevelopment through 2005 simulation was calibrated using an automated parameter-estimation method to optimize the fit to pre-1940 groundwater levels and base flows, 1945 through 2005 decadal groundwater-level changes, and 1940 through 2005 base flows. The calibration results of the pre-1940 period indicated that 81 percent of the simulated groundwater levels were within 30 feet of the measured water levels. The results did not indicate large areas of simulated groundwater levels that were biased too high or too low, indicating that the simulation generally captures the regional trends. Calibration results using 1945 through 2005 decadal groundwater-level changes indicated that a majority of the simulated groundwater-level changes were within 5 feet of the changes calculated from measured groundwater levels. Simulated groundwater-level rises generally were smaller than measured rises near surface-water irrigation districts. Simulated groundwater-level declines were larger than measured declines in several parts of the study area having large amounts of irrigated crops. Base-flow trends and volumes generally were reproduced by the simulation at most sites. Exceptions include downward trends of simulated base flow from the 1970s to the end of the calibration period for the Elkhorn River at Norfolk, Beaver Creek at Genoa, and Cedar River near Fullerton.
Effects of groundwater irrigation on stream base flow were predicted using several methods: (1) simulated base-flow depletion was mapped to represent the percentage of water pumped from a hypothetical well during 2006 through 2055 that corresponds to base-flow depletions at the end of that 50 -year period; (2) the groundwater-flow simulation predicted changes in stream base flow that result from modifying the number of irrigated acres in a 25-year period (2009 through 2033); and (3) a simulation-optimization model determined the minimum reduction of groundwater pumpage that would be necessary in the Elkhorn River Basin in a 25-year period (2009 through 2033) to comply with various hypothetical base-flow requirements for the Elkhorn River. The results are not intended to determine specific management plans that must be adopted, but rather to improve the understanding of how base flow is affected by irrigation.

A 50-year simulation (2006-55) indicated that depletions of less than 10 percent of pumpage mainly occur in areas that are about 10 miles or farther from the Elkhorn and Loup Rivers and their tributaries.

The calibrated simulation was used to predict the 25 -year effect on base flow of a 10 percent decrease in irrigated acres and the effect of increasing acres at the presently (2010) allowed rate. Hypothesized changes to irrigated acres were applied only to areas where mapped base-flow depletions were at least 10 percent of pumpage. The effect of changes in irrigated acres includes the combined effects of changes to pumpage and additional recharge from irrigated acres. When irrigated acres were decreased by 10 percent within selected areas of four Natural Resources Districts (a total reduction of about 120,000 acres and a 5 percent reduction in irrigation pumpage), simulated base flow was predicted to increase by as much as 13.0 cubic feet per second in the Loup River Basin and by as much as 23.8 cubic feet per second in the Elkhorn River Basin. The largest increases to base flow were simulated at downstream locations. When irrigated land was increased by about 25,000 acres, predicted base flow decreased by a maximum of 2.9 cubic feet per second in the Loup River Basin and by as much as 6.9 cubic feet per second in the Elkhorn 
River Basin. Changes to base flow were related to the proximity of the hypothetical newly irrigated acres to a stream.

When a simulation-optimization model was formulated to maximize pumpage, while maintaining base flow in two key reaches of the Elkhorn River at the estimated rate needed to support the average historical frequency (about 70 percent) at which streamflow met or exceeded an in-stream flow criterion for a downstream reach in the Platte River, maximum overall pumpage was optimized when simulated pumpage within the Lower Elkhorn Natural Resources District was reduced by approximately 40 percent and pumpage within the Upper Elkhorn Natural Resources District was reduced by about 8 percent. When the simulation-optimization model was formulated to maximize pumpage, while maintaining base flow in the two key reaches of the Elkhorn River at a more conservative estimated rate (at 65 percent of 2005 simulated base flow) needed to support the in-stream flow criterion, maximum overall pumpage was optimized when simulated pumpage within the Lower Elkhorn Natural Resources District was reduced by about 49 percent and pumpage within the Upper Elkhorn Natural Resources District was reduced by about 17 percent. Neither of these two base-flow target rates are regulatory requirements, but the results provide benchmarks for the Natural Resources Districts for determination of appropriate management goals.

Accuracy of the simulations is affected by input data limitations, system simplifications, assumptions, and resources available at the time of the simulation construction and calibration. Most of the important limitations relate either to data used as simulation inputs or data used to estimate simulation inputs. Development of the regional simulations focused on generalized hydrogeologic characteristics within the study area, and did not attempt to describe variations important to local-scale conditions. For example, a single unconfined layer was used to simulate the aquifer. Therefore, these simulations are most appropriate for analyzing groundwater-management scenarios over large areas and long time periods, and are not reliable for analysis of small areas or short time periods.

\section{Introduction}

In central and eastern Nebraska, the Elkhorn and Loup Rivers provide streamflow for irrigation, recreation, hydropower production, aquatic life, and municipal water systems for the Omaha and Lincoln metropolitan areas. In addition, the Elkhorn and Loup Rivers merge with the Platte River near Waterloo and Columbus, Nebraska (inset, fig. 1), respectively, contributing to satisfying in-stream flow appropriations [such as Nebraska Game and Parks Commission In-Stream Appropriation A-17331, established for the Platte River between its mouth and the confluence with the Elkhorn River (Nebraska Department of Natural Resources, 1998)].

State legislation requires a sustainable balance between long-term water supplies and uses of surface water and groundwater (Nebraska Department of Natural Resources, 2006). Thus, in 2006, the U.S. Geological Survey (USGS), the Nebraska Department of Natural Resources (NDNR), the University of Nebraska's Conservation and Survey Division, and the Lewis and Clark, Lower Elkhorn, Lower Loup, Lower Niobrara, Lower Platte North, Middle Niobrara, Upper Elkhorn, and Upper Loup Natural Resources Districts (NRDs, collectively referred to hereinafter as ELM NRDs) agreed to cooperatively study the water resources of these basins to develop the Elkhorn-Loup Model (ELM). The first part of that study, hereinafter referred to as "phase one," was a first step toward understanding long-term average stream-aquifer system conditions and developing strategies for management of hydrologically connected groundwater and surface-water supplies in the study area. Phase one, documented by Peterson and others (2008), mainly focused on using pre-existing data to develop a regional groundwater-flow simulation and predict the effects of groundwater irrigation on stream base flow in the Elkhorn and Loup River Basins.

\section{Phase-Two Study}

Continuation of the study beyond phase one was part of a larger, ongoing effort to enhance the knowledge of hydrogeology, improve the understanding of stream-aquifer interactions, and compile reliable data describing hydrogeologic properties and groundwater recharge, groundwater pumpage for irrigation, and groundwater discharge to evapotranspiration in the study area. This study extension, hereinafter referred to as "phase two," included updates to the groundwater-flow simulation using newly collected data and supporting analyses completed in 2007 and 2008, improved simulation calibration methods, and additional approaches for analyzing the effects of agricultural irrigation using the simulation. The newly collected data include revisions to the base-of-aquifer map using test-hole drilling and surface and borehole geophysics (McGuire and Peterson, 2008), synoptic base-flow measurements along stream reaches (Peterson and Strauch, 2007), a runoff-recharge watershed model to estimate longterm patterns of recharge (Strauch and Linard, 2009), and geophysical mapping of resistivity patterns in canals (Teeple and others, 2009). In addition to improving the data used for the simulations, parameter-estimation techniques were used for phase-two simulation calibration, providing a more robust calibration. Other enhancements to the simulations included refining the grid discretization, using time-variable recharge from precipitation, time-variable base-flow estimates, improved estimates of groundwater withdrawals for irrigation, and refined delineation of active evapotranspiration grid cells. A summary of the groundwater-flow simulation updates is presented in appendix 1 .

The ELM study area covers approximately 30,000 square miles $\left(\mathrm{mi}^{2}\right)$, and extends from the Niobrara River in the north to the Platte River in the south (fig. 1). The western boundary roughly coincides with the western boundary of the Upper 


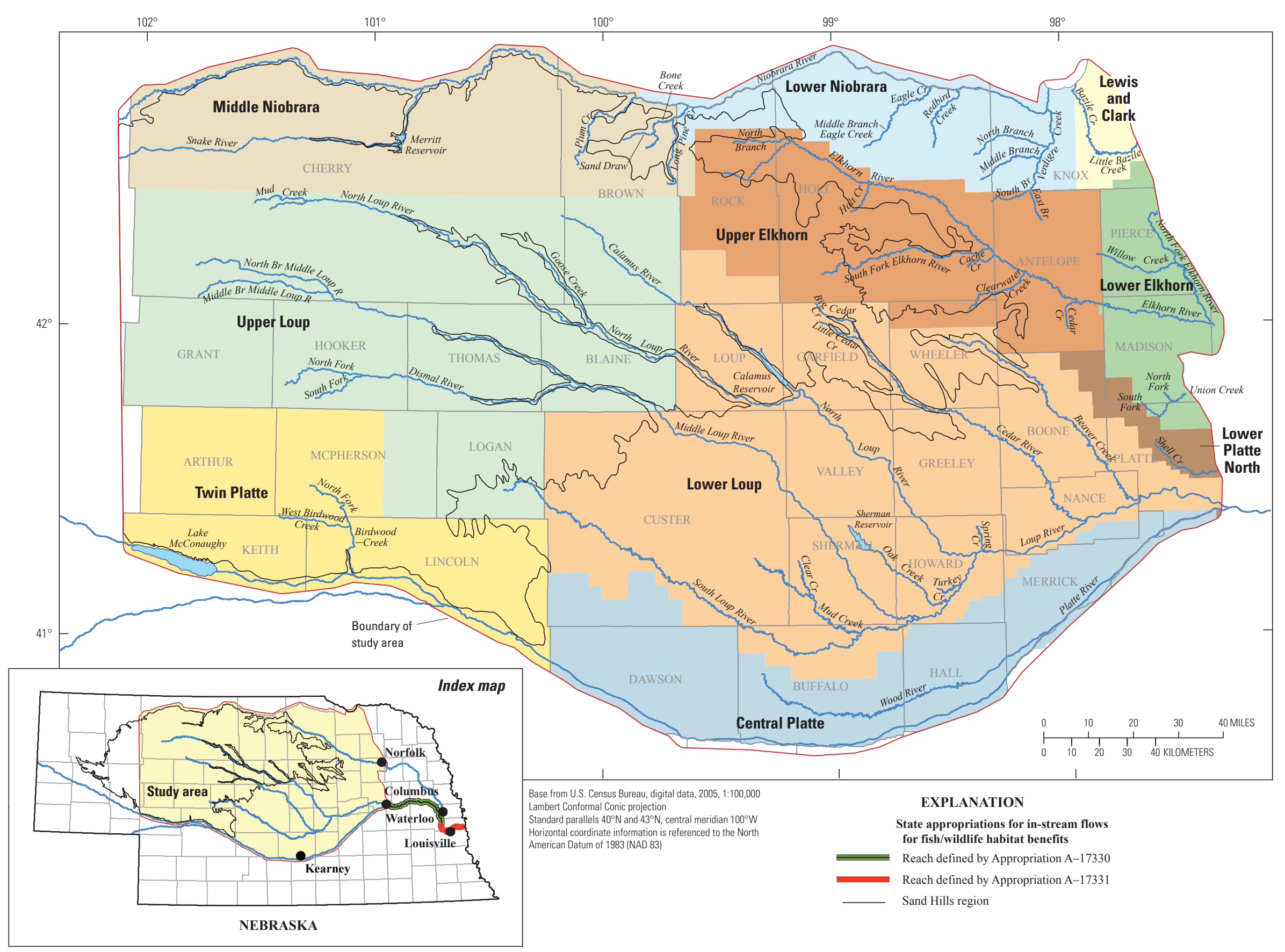

Figure 1. Location of the Elkhorn-Loup Model study area, Elkhorn and Loup River Basins, Nebraska. 
Loup NRD, and the eastern boundary roughly coincides with the approximate location of the westernmost extent of glacial till in eastern Nebraska (Conservation and Survey Division, 2005c). Quaternary-age wind-deposited loess and fine-grained sand; alluvial silt, sand, and gravel of Quaternary age; and Tertiary-age silt, sand, and gravel of the Ogallala Group (Condra and Reed, 1943) constitute the important geologic deposits of the High Plains aquifer in the study area.

\section{Purpose and Scope}

This report presents the phase-two groundwater-flow simulations and predicted effects of groundwater irrigation on stream base flow in the Elkhorn and Loup River Basins of central Nebraska. This report describes the construction and calibration of the simulations and the methods used to predict changes to stream base flow that result from changes to groundwater irrigation. Effects of groundwater irrigation were evaluated using three distinct approaches: (1) a base-flow depletion analysis, derived from results of the model simulation, mapped the spatial distribution of the percentage of pumped water that causes base-flow depletion at the end of a 50-year period; (2) groundwater-flow simulations were used to predict changes to stream base flow that resulted from changes to the amount of irrigated area during a 25-year period; and (3) a simulation-optimization model determined the minimum reduction of groundwater pumpage that would be necessary in the Elkhorn River Basin to maintain various hypothetical levels of base flow in the Elkhorn River. The climate, land use, water use and management, hydrogeology, and general description of the conceptual model were described by Peterson and others (2008) and are not presented herein.

\section{Simulation of Groundwater Flow}

This section describes the topical background, methods, and results for developing the phase-two simulation of groundwater flow. The simulation, or model, was developed to simulate groundwater flow, groundwater withdrawals, and stream-aquifer interactions for the Elkhorn and Loup River Basins, Nebraska. To simulate those processes, large amounts of hydrogeologic data from numerous sources were needed to describe aquifer properties and hydrologic stresses. These data were compiled as spatially referenced data layers within a geographic information system (GIS) and then assigned to the simulation at discrete intervals in space and time. Simulations were built for this study using MODFLOW-2005 (Harbaugh, 2005), with assistance from Groundwater Vistas Version 5 software (Environmental Simulations, Inc., 2009).

The hydrogeologic data (simulation parameters) describing the study area were assigned to the simulation directly and through calibration. For the direct case, characteristics such as recharge, land use, streambed properties, and hydraulic conductivity were introduced into the simulation using the best available information (appendix 1) and used as compiled. Once all available information was compiled and entered into the simulation, the results from the simulation were compared to measured groundwater levels, decadal groundwater-level changes, and estimated groundwater discharge to streams (hereinafter referred to as base flow). Differences between simulation results and values were used to guide calibration, which is the process of obtaining parameter values to construct a framework useful for describing the hydrogeologic characteristics of the study area (Reilly and Harbaugh, 2004).

Simulations were calibrated by adjusting selected parameters until simulated groundwater levels, decadal groundwaterlevel changes, and base flow best reproduced measured values (see "Calibration" section of this report). Calibration proceeded in two stages. In the first stage, manual trial-and-error calibration techniques were used to adjust average recharge from precipitation, additional recharge beneath irrigated and nonirrigated cropland, horizontal hydraulic conductivity $\left(\mathrm{K}_{\mathrm{H}}\right)$, streambed hydraulic conductivity $\left(\mathrm{K}_{\mathrm{S}}\right)$, and maximum evapotranspiration (ET) rates from groundwater to achieve the best match with measured groundwater levels, decadal groundwater-level changes, and base-flow data. Recharge from precipitation was calibrated as a constant, average rate throughout the simulation period rather than a time variable rate during the manual trial-and-error calibration stage.

The second stage of calibration used automated calibration techniques and incorporated recharge from precipitation as a temporally changing value. The automated, or inverse modeling, calibration stage used the Parameter Estimation software (PEST) (Doherty, 2008a, 2008b) (appendix 2). Adjustable parameters for the automated calibration were recharge from precipitation and $\mathrm{K}_{\mathrm{H}}$.

\section{Spatial and Temporal Discretization}

To simulate flow using MODFLOW, the study area is divided into a grid of discrete cells. Hydrogeologic properties, initial conditions, and simulation results are assigned to each grid cell. The actual hydrogeologic system is continuous rather than discrete; therefore, groundwater-flow simulations are always an approximation of the actual system. Simulations with a smaller grid-cell size generally yield more accurate approximations of the actual system because less averaging occurs as spatially variable properties are assigned to grid cells, especially where large changes take place over small distances. The study area was simulated using a uniformly spaced grid of 162 rows and 248 columns of 1-mile (mi) by 1-mi cells, covering an area of $40,176 \mathrm{mi}^{2}$ (fig. 2). This is a refinement of the phase-one simulation, which used grid cells $2 \mathrm{mi}$ by $2 \mathrm{mi}$ in extent. The active simulation area, which is smaller than the extent of the model domain, encompasses $29,707 \mathrm{mi}^{2}$ and includes areas with an estimated aquifer saturated thickness of at least 10 feet (ft). Similar to the phase-one simulations, a single unconfined layer was used to simulate the aquifer. 


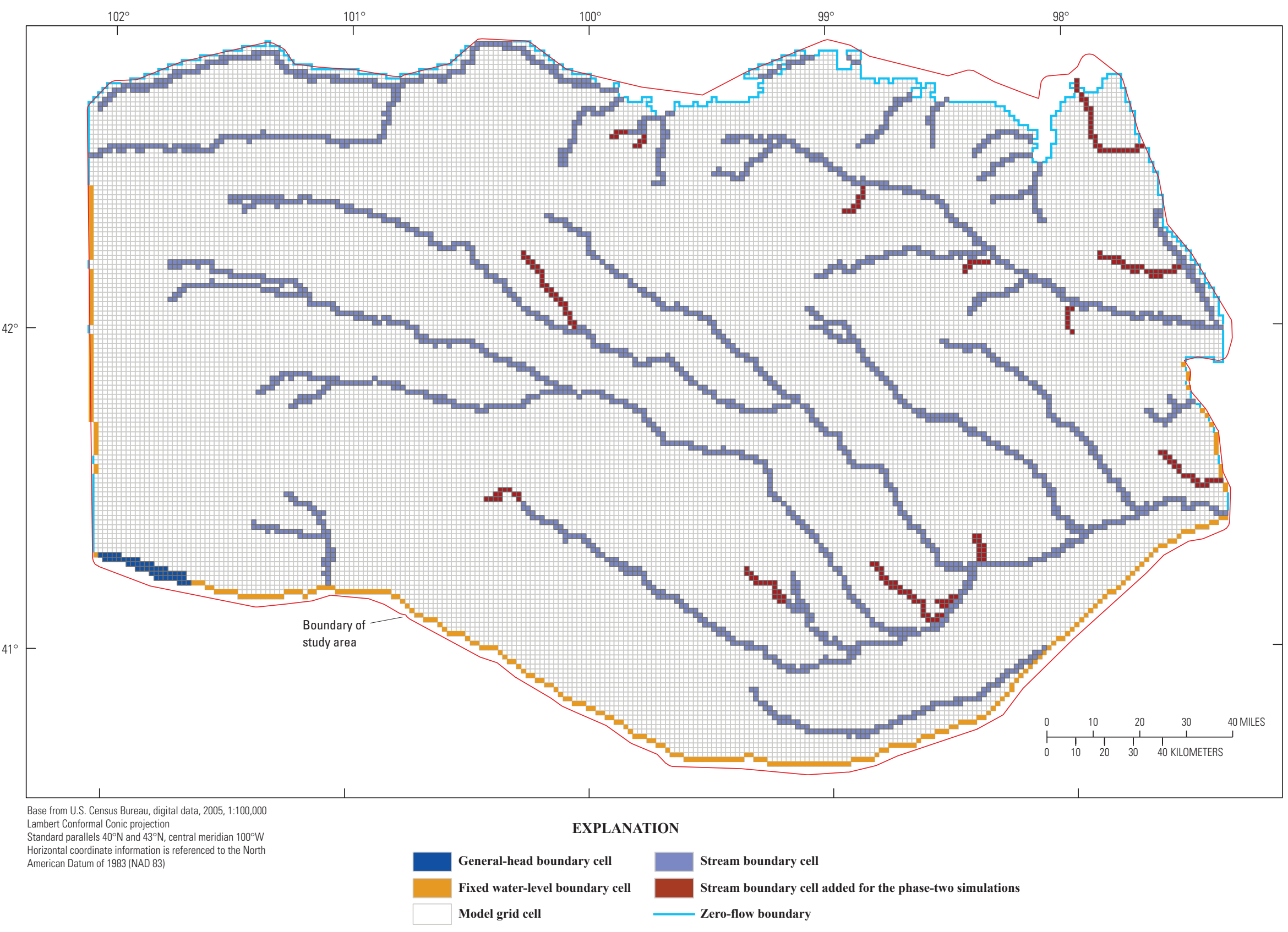

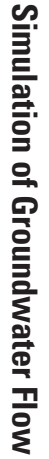

Figure 2. Model grid and boundary cells of the Elkhorn-Loup Model, Elkhorn and Loup River Basins, Nebraska. 
If a simulation is used to evaluate the aquifer system as a function of time, it is referred to as a transient simulation and is divided into discrete time intervals called stress periods. Hydrologic stresses, such as recharge and pumping, are held constant within each stress period. In the ELM study area, major changes in land-use practices occurred from 1895 to 1940 and from 1940 through 2005. Starting in 1895, irrigation canals were constructed, and water was diverted from streams for agriculture. Simulation of conditions from 1895 through 1939 used two stress periods (1895 to 1929 and 1929 through 1939) to represent the two time periods when new canal systems became operational and caused a change to recharge from canal seepage (see "Additional Recharge from Canal Seepage"). From 1940 through 2005, irrigated agriculture expanded to include wells and additional canals. The 1940 through 2005 period was simulated using 66 stress periods, one stress period for each year. Simulated hydrologic stresses were updated during each of those annual stress periods so that changes to land use and irrigation development with time are represented in the simulation.

Groundwater levels were needed to represent 1895 conditions at the beginning of the simulation (Reilly and Harbaugh, 2004) and measured groundwater levels were unavailable during 1895; therefore, a pre-1895 period was simulated to represent the system in long-term equilibrium, or steady-state conditions. When a steady-state simulation is used to define starting conditions for a transient simulation, the steady-state simulation uses the same aquifer properties and hydrologic stresses, with the exception of stresses such as pumping. This period was simulated using a single transient stress period that was 1,000 years long. It was determined that 1,000 years was a sufficient amount of time to reproduce long-term equilibrium conditions because simulated change to groundwater storage was close to zero. This approach was used in place of a true steady-state stress period, a single stress period having a single time step and a storage term set to zero, because it helped prevent numerical instability in the far northeast corner of the study area and resulted in fewer dry cells. Dry cells are cells that become inactive when calculated interim groundwater levels drop below the simulated base of the aquifer during the iterative approximations of groundwaterflow equations (Harbaugh, 2005). During calibration, simulated results of the pre-1895 period were not compared to calibration targets; however, 1895 simulated groundwater levels were used as starting groundwater levels for the 1895 through 1939 simulation, and 1939 simulation results were compared to measured groundwater levels and estimated base flows (see "Calibration" section of this report). This was considered appropriate because water development from 1895 through 1939 only occurred in a relatively small area along the southern boundary of the simulation.

\section{Aquifer Properties}

Initial horizontal hydraulic conductivity $\left(\mathrm{K}_{\mathrm{H}}\right)$ values were calculated using available transmissivity values and aquifer saturated thickness. Transmissivity was calculated using $\mathrm{K}_{\mathrm{H}}$ values that were estimated from grain size, degree of sorting, and silt content of the saturated aquifer sediments (Goeke and others, 1992). $\mathrm{K}_{\mathrm{H}}$ values for specific intervals of available lithologic logs were multiplied by the thickness of the interval and summed for the entire log. Transmissivity data were obtained in that manner from 1,055 test-hole logs drilled before 2004 in the study area and contours of transmissivity based on those test-hole logs (Conservation and Survey Division, 2005a; Rick Vollertsen, Nebraska Department of Natural Resources, written commun., 2005). Saturated thickness was calculated by subtracting the interpolated aquifer base from the maximum water-table elevations available from previously published groundwater-level elevation contour maps for 1979 and 1995 (Conservation and Survey Division, 1996c, 2003). The maximum water-table elevation was used to avoid potentially small saturated thicknesses causing unreasonably large $\mathrm{K}_{\mathrm{H}}$ values. $\mathrm{K}_{\mathrm{H}}$ values were calculated by dividing interpolated transmissivity by interpolated saturated thickness.

The study area was originally divided into 14 homogeneous $\mathrm{K}_{\mathrm{H}}$ zones based on calculated $\mathrm{K}_{\mathrm{H}}$ values and expected regional patterns of $\mathrm{K}_{\mathrm{H}}$, which assumed that the coarseness or fineness of the deposits was related to the depositional environment, as indicated by the paleogeography interpreted from the base-of-primary-aquifer contours. The expected regional patterns also assumed $\mathrm{K}_{\mathrm{H}}$ values would be different in areas where Quaternary-age deposits were more prevalent. The use of hydrogeologic zones in the simulation is a simplification of the real groundwater system that was needed because it was not feasible to calibrate $\mathrm{K}_{\mathrm{H}}$ values independently for each grid cell. The actual distribution of $\mathrm{K}_{\mathrm{H}}$ is always more complex than available data can describe or a simulation can represent. Stochastic techniques are available that allow a more continuous distribution of simulation inputs such as $\mathrm{K}_{\mathrm{H}}$ (for example Fienen and others, 2009; Hunt and others, 2007); however, time and budgetary constraints prevented those techniques from being used for this study.

Initial $\mathrm{K}_{\mathrm{H}}$ values were set to the average calculated $\mathrm{K}_{\mathrm{H}}$ within each zone. During the manual trial-and-error process, $\mathrm{K}_{\mathrm{H}}$ zones were progressively refined and additional zones were added based on patterns of simulated groundwater levels calculated at the end of the pre-1940 period as compared to measured groundwater levels (see "Calibration" section of this report) and spatial patterns of interpolated $\mathrm{K}_{\mathrm{H}}$ as a function of transmissivity. Through this progressive refinement, 91 zones ultimately were defined, and a uniform $\mathrm{K}_{\mathrm{H}}$ was used as a simulation parameter within each zone.

$\mathrm{K}_{\mathrm{H}}$ was adjusted during the manual trial-and-error process until the best reproduction of measured pre-1940 groundwater levels and estimated long-term average base flow was reached. $\mathrm{K}_{\mathrm{H}}$ values were further refined during the automated calibration process. Lower and upper limits of $\mathrm{K}_{\mathrm{H}}$ were set to 5 feet per day (ft/d) and $1,000 \mathrm{ft} / \mathrm{d}$ during the automated calibration process so that extreme values were not considered (appendix 2). Prior information derived using regularization (appendix 2) also was used to constrain $\mathrm{K}_{\mathrm{H}}$. 
Regularization is a technique that can be used during automated calibration to inform the process that there is a certain level of confidence associated with initial parameter values, $\mathrm{K}_{\mathrm{H}}$ in this case. During calibration, regularization prevented the process from greatly deviating from initial values. This was appropriate because test-hole logs provided a large amount of hydrogeologic information across the study area. Final calibrated $\mathrm{K}_{\mathrm{H}}$ values ranged from 5.5 to $107 \mathrm{ft} / \mathrm{d}$ and did not reach the imposed lower and upper limits; therefore, the limits did not constrain the final outcome of the calibrated $\mathrm{K}_{\mathrm{H}}$ values (fig. 3). Most values ranged from 10 to $50 \mathrm{ft} / \mathrm{d}$ with larger values occurring in the southern and eastern parts of the study area. These values generally were similar to the calculated $\mathrm{K}_{\mathrm{H}}$ values derived from test-hole logs. About 67 percent of the $\mathrm{K}_{\mathrm{H}}$ zones had a calibrated $\mathrm{K}_{\mathrm{H}}$ value that differed by less than $20 \mathrm{ft} / \mathrm{d}$ from the average of the $\mathrm{K}_{\mathrm{H}}$ values calculated from test-hole logs within that zone. About 76 percent of the $\mathrm{K}_{\mathrm{H}}$ zones had a calibrated $\mathrm{K}_{\mathrm{H}}$ value that was within $30 \mathrm{ft} / \mathrm{d}$ of the average of the $\mathrm{K}_{\mathrm{H}}$ values calculated from test-hole logs within that zone.

Specific yield, which is the storage parameter that characterizes the ability of an aquifer to yield water by drainage of the sediment pores (Freeze and Cherry, 1979), was one of the few simulation inputs that remained unchanged from the phase-one simulation (Peterson and others, 2008). Values were interpolated from 1,055 test-hole logs and contour lines interpreted from those logs (Conservation and Survey Division, $2005 b)$. Interpolated values ranged from 0.002 to 0.260 with a mean of 0.154 (dimensionless). Smaller values were located in the northeastern part of the study area near the Niobrara River Valley. Areas of larger specific yield were located in the southwestern counties of Arthur, Grant, Hooker, Keith, and McPherson Counties and the southeastern counties of Boone, Hall, Merrick, and Platte Counties (fig. 1). Specific yield was not adjusted during the calibration process.

Specific storage accounts for the decompression and expansion of water when groundwater levels are lowered (Freeze and Cherry, 1979). It reflects the amount of water that is obtained as aquifer materials undergo compression when water is removed. In regional unconfined flow systems, this amount of water typically is ignored because it is much smaller than the amount of water yielded through aquifer drainage. For this study, specific storage was set to a uniform value of 0.00001 feet $^{-1}\left(\mathrm{ft}^{-1}\right)$. Specific storage was not adjusted during the calibration process.

\section{Hydrologic Stresses}

Hydrologic stresses are features that supply or remove water from the hydrologic system. Simulated hydrologic stresses were flows into and out of the lateral boundaries of the study area; seepage to and from streams; well pumpage for irrigation and municipal supply; recharge from precipitation; additional recharge beneath irrigated and nonirrigated agricultural land; additional recharge from canal seepage; discharge to evapotranspiration; and seepage to and from Lake McConaughy.

\section{Flow Across Lateral Boundaries}

Groundwater flow into and out of the outer extent of the study area was represented by a series of grid cells along the edge of the active simulation area having groundwater levels that do not change as a result of simulation calculations (fig. 2). As water flows from these fixed water-level boundary cells to other nearby cells downgradient, or as upgradient water flows to fixed water-level boundaries, water is added to or removed from the simulated flow system to maintain the groundwater level at the assigned elevation.

Flow directions near lateral boundaries were interpreted from a 1995 water-table elevation contour map (Conservation and Survey Division, 2003). Generally, groundwater flow entered the study area from the west and exited the study area in the east. In these areas, fixed groundwater levels were set to values obtained from interpretations of the 1995 water-table elevation contours. A fixed water-level boundary also was used for the southern boundary to represent groundwater discharge to the Platte River, or in some cases, water being lost by the Platte River to the groundwater system. Fixed water-level elevations for the southern boundary were assigned based on 10-meter digital elevation model elevations (Nebraska Department of Natural Resources in work-share agreement with the U.S. Geological Survey, 1998). In the long-term, groundwater levels at the Platte River (represented by stream stage) do not change more than a few feet; therefore, use of a fixed water-level boundary seemed appropriate and unlikely to affect simulation results in the interior of the simulation. This assumption was tested by increasing and decreasing the fixed water-level boundary elevations along the Platte River by $10 \mathrm{ft}$ and measuring changes to simulated base flow in 2005. These tests indicated that the maximum change to simulated base flow was 2 cubic feet per second $\left(\mathrm{ft}^{3} / \mathrm{s}\right)$, or about 1 percent, at a location on Birdwood Creek that was immediately adjacent to the southern fixed water-level boundary. Most simulated base flows did not change when the fixed water-level boundary elevation was adjusted by $10 \mathrm{ft}$.

Cells along the external boundary of the study area that did not have fixed water levels were assumed to have no groundwater flow into or out of the study area. These "zeroflow" boundaries were used for some reaches of the northern external boundary because the aquifer thins from south to north before reaching the Niobrara River. In these areas, the aquifer is thin or absent, and the Niobrara River generally flows across Cretaceous-age bedrock low in hydraulic conductivity (Conservation and Survey Division, 1996a, 1996b). A zero-flow boundary also was used for parts of the eastern and western simulation boundaries where flow was dominantly parallel to the external boundary, thus no flow crosses the external boundary. A zero-flow boundary was used for the northern part of the eastern boundary, where the aquifer is extremely thin and has a low hydraulic conductivity, indicating 


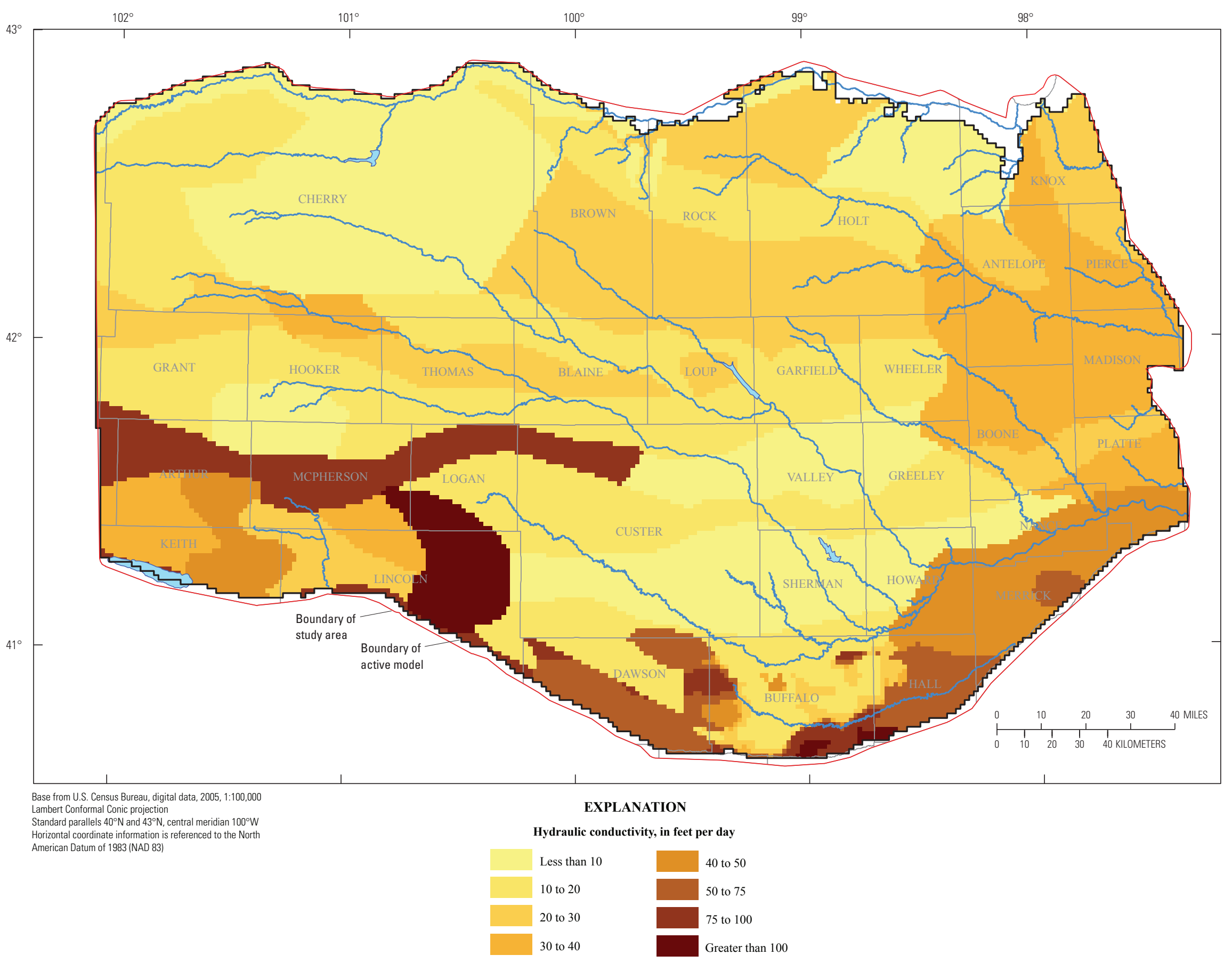

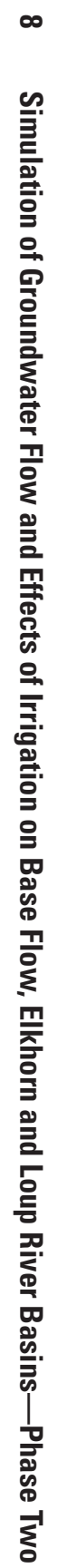

Figure 3. Calibrated hydraulic conductivity, Elkhorn and Loup River Basins, Nebraska. 
that flow is negligible for the regional system (Conservation and Survey Division, 2005a). Finally, a zero-flow boundary was used for the boundary at the base of the aquifer because minimal water exchange is expected between the aquifer and the underlying low-hydraulic conductivity bedrock.

\section{Streambed Seepage}

A number of smaller streams were added to the phasetwo simulation (fig. 2; Peterson and others, 2008, fig. 1). The criterion to add a stream was that it had to have at least $5 \mathrm{ft}^{3} / \mathrm{s}$ of measured base flow in 2006 (Peterson and Strauch, 2007). If only a portion of a stream length had at least $5 \mathrm{ft}^{3} / \mathrm{s}$ of observed base flow, only that portion of the stream was added to the simulation. At least $5 \mathrm{ft}^{3} / \mathrm{s}$ was chosen because it was deemed a sufficiently small value to ensure that all streams of importance to a regional groundwater-flow simulation would be included, and because the contribution of streamflows smaller than $5 \mathrm{ft}^{3} / \mathrm{s}$ to the overall hydrologic budget was generally deemed negligible. Two exceptions were allowed to this criterion. Bazile and Willow Creeks were added to the simulation because they were of particular interest to local water-resources managers. Base flow was not measured at Bazile Creek in 2006; however, it did have at least $5 \mathrm{ft}^{3} / \mathrm{s}$ of measured base flow in 2007 (Amanda Flynn, U.S. Geological Survey, written commun., 2008). At least one-half of the stream length added for Willow Creek had at least $5 \mathrm{ft}^{3} / \mathrm{s}$ of measured base flow in 2006 .

Seepage to and from streams was simulated using the MODFLOW Streamflow-Routing Package (SFR2, Version 7.1). Streambed seepage is controlled by physical characteristics of the streambed and the relative elevations of the stream stage and groundwater level; the amount of streamflow gain or loss is controlled by the magnitude of difference between stream stage and groundwater-level elevations and streambed characteristics (Niswonger and Prudic, 2005). The streambed represents the boundary between the stream and the underlying aquifer sediments. A simulated stream may contribute the routed water back to the aquifer when the simulated groundwater elevation under the streambed is lower than the simulated stream stage.

Streambed characteristics included in the StreamflowRouting Package are hydraulic conductivity of the saturated streambed sediments $\left(\mathrm{K}_{\mathrm{S}}\right)$, stream width, stream length, and streambed thickness. $\mathrm{K}_{\mathrm{S}}$ is a poorly constrained simulation parameter and initially was set equal to the aquifer horizontal hydraulic conductivity $\left(\mathrm{K}_{\mathrm{H}}\right)$ value that was assigned to the same grid cell. $\mathrm{K}_{\mathrm{S}}$ was then adjusted during the manual trial-and-error calibration process. Each major stream and its associated tributaries were adjusted separately during calibration. Geophysical data obtained from continuous-resistivity profiling (Teeple and others, 2009) provided additional information about the relative potential for interaction between surface water and groundwater along the Middle Loup River near Thedford and the North Loup River near Ord (fig. 4). $\mathrm{K}_{\mathrm{s}}$ values were adjusted at the cells coinciding with geophysical data collection such that cells with a greater relative potential for interaction had larger $\mathrm{K}_{\mathrm{S}}$ values and cells with less relative potential for interaction had smaller $\mathrm{K}_{\mathrm{S}}$ values. The average $\mathrm{K}_{\mathrm{S}}$ value of the adjusted cells at a site was kept the same. This approach was used because the geophysical data were reported in relative terms and not as quantified $\mathrm{K}_{\mathrm{S}}$ values. $\mathrm{K}_{\mathrm{S}}$ values determined during manual calibration ranged from less than 0.10 to $6.0 \mathrm{ft} / \mathrm{d}$ (fig. 4). Stream width was defined using measurements made at about 250 locations along streams during the synoptic base-flow study (Peterson and Strauch, 2007). Stream length was calculated within a GIS. Streambed thickness was uniformly set to $1 \mathrm{ft}$. Streambed thickness also is a poorly constrained simulation parameter; however, an accurate representation of streambed thickness was not necessary because the Streamflow-Routing Package combines all streambed characteristics into one term that is used by MODFLOW. Because one of the streambed characteristics, $\mathrm{K}_{\mathrm{s}}$, was a calibrated simulation parameter, it was not necessary to calibrate the simulation to the remaining streambed characteristics (stream width, stream length, and streambed thickness).

\section{Well Pumpage}

Simulated well pumpage included aquifer withdrawals for crop irrigation and municipal water supply. The amount of groundwater pumped from the aquifer for irrigation in the study area has only recently been measured (since 2003); therefore, net pumpage for irrigation water was estimated. Estimates of net irrigation pumpage required a number of assumptions related to the number and location of groundwater- and surface-water-irrigated acres, the amount of water needed by crops, the portion of the crop water requirement that was met by precipitation, measured pumpage values, and the amount of the measured pumpage returning to the aquifer. Because the uncertainty of many of these quantities is unknown, the estimated values of components of the estimation processes, along with the results, need to be used with caution.

Methods for estimating net irrigation pumpage are summarized here and explained below. Steps for estimating net irrigation pumpage were the same as had been used for the phase-one simulation: (1) estimate yearly distribution of irrigated acres by crop, (2) estimate the portion of irrigated acres, by crop, supplied by surface-water irrigation and groundwater pumpage, (3) estimate the total amount of water needed by each type of crop $\left(\mathrm{Crop}_{T O T}\right)$, (4) determine the portion of the total crop water requirement that is satisfied by precipitation $\left(\right.$ Precip $\left._{E F F}\right)$, (5) calculate the irrigation requirement for each crop (Crop TOT $_{\text {minus Precip }}$ EFF $)$, (6) compare the calculated irrigation requirement for each crop with the average measured pumping rate for each crop (adjusted for the estimated amount of water in excess of irrigation requirement that percolates (or infiltrates) through the unsaturated zone and returns to the aquifer), and (7) adjust the calculated irrigation requirement for each crop to make the calculated crop irrigation requirement match the adjusted measured pumpage values. The resulting adjusted irrigation requirement is herein referred to as net irrigation pumpage. 


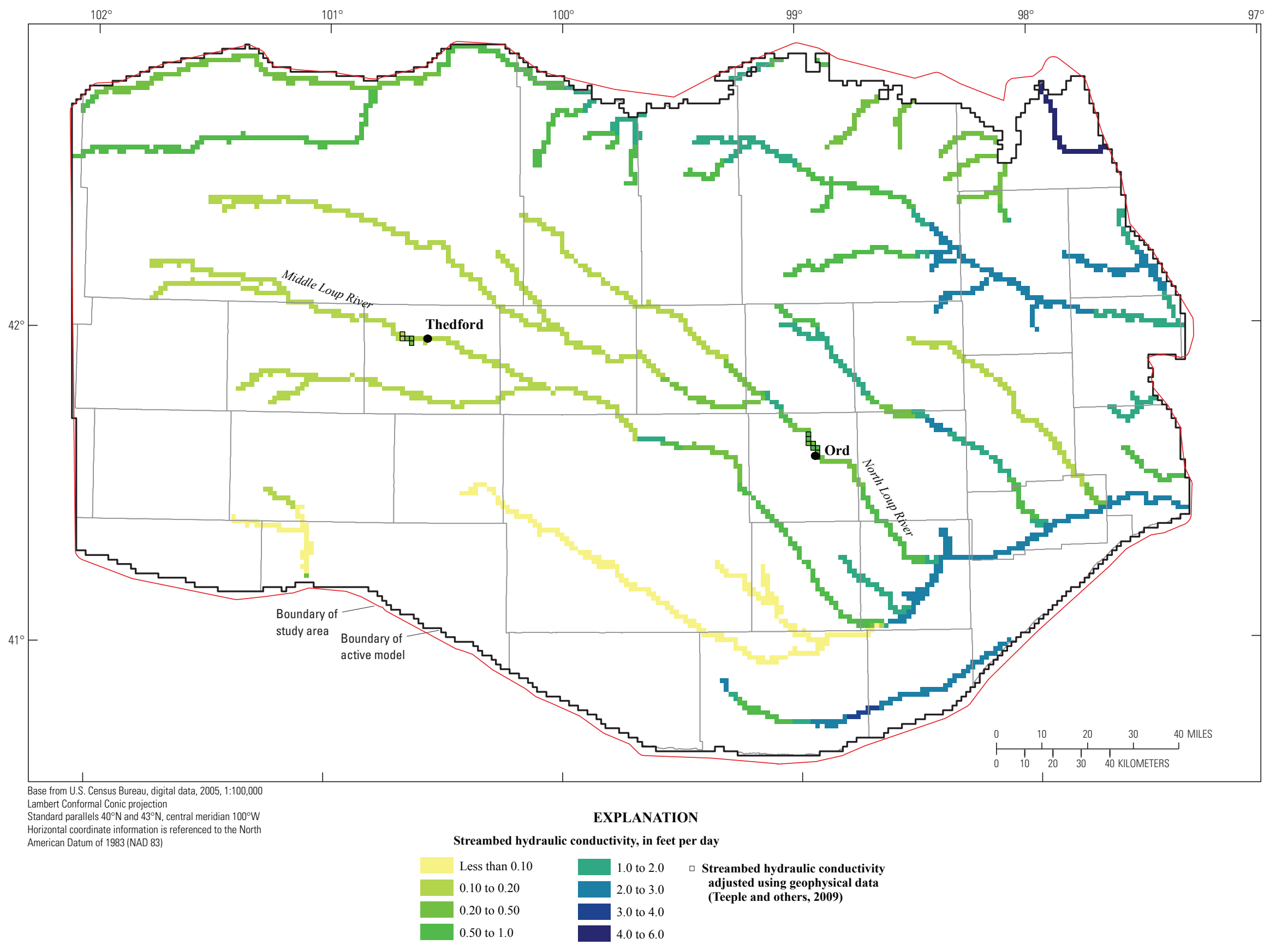

Figure 4. Calibrated streambed hydraulic conductivity, Elkhorn and Loup River Basins, Nebraska. 
Estimated pumpage for irrigation was dependent on the annual distribution of land use. Land-use data were estimated using the spatial distribution of land-use classes in 2005 and Census of Agriculture county-level crop statistics (Rich Kern, Nebraska Department of Natural Resources, written commun., 2008). The distributions of irrigated and nonirrigated crop types for 2005 were obtained from the Center for Advanced Land Management Information Technologies (CALMIT) remote sensing data (Center for Advanced Land Management Information Technologies, 2007).

Pre-2005 land-use data were estimated based on countylevel crop statistics in the Census of Agriculture (U.S. Department of Agriculture, variously dated). The Census of Agriculture provided the number of nonirrigated and irrigated acres for each crop grown in each county every 5 years from 1950 to 2002. To produce the annual data required for the 1940 through 2005 period, yearly county-level values were interpolated linearly between the data values published every 5 years for 1950 to 2002. Crop acres from 1940 to 1949 were set equal to 1950 values because data were not available before 1950 . The mapped land use for 2005 was adjusted by a multiplier so that the total for each county for 2004 and preceding years matched the data interpolated from the Census of Agriculture data for each year. In the final data set used for the simulation, the number of acres assigned to each classification in each county matched the Census of Agriculture county-level statistics or the interpolation between the published years. If a county was only partially within the study area, the number of acres of each irrigated and nonirrigated crop was reduced by the proportion of the total county land area that was outside the study area.

Land-use data did not provide information about the source of irrigation water, so the distribution of groundwater-irrigated acres had to be estimated before groundwater pumpage could be calculated. Maps of surfacewater-irrigated areas and tables of yearly total acres irrigated by surface water were provided by Daniel Kloch (Nebraska Department of Natural Resources, written commun., 2008), Rick Vollertsen (Nebraska Department of Natural Resources, written commun., 2005), Allan Schmidt (Middle Loup Public Power and Irrigation District, written commun., 2006), Mel Brozek (Sargent Irrigation District, written commun., 2006), Jack Wergen
(Bureau of Reclamation, written commun., 2006), Darwin Lee (Farwell Irrigation District, written commun., 2006), William Peck (Bureau of Reclamation, written commun., 2006), and Ron Wolf (Twin Loups Irrigation District, written commun., 2006). Maps provided the spatial distribution of surface-waterirrigated acres across each canal district for recent conditions but historical spatial distributions were not available; therefore, historical distributions of acres were estimated by increasing or decreasing the mapped acres in proportion to the yearly total number of acres irrigated by surface water. The distribution of surface-water-irrigated acres within the North Loup River Public Power and Irrigation District was not well defined; therefore, the acres were divided evenly among all grid cells within that district's area, assuming that surface-water irrigation would be distributed evenly throughout that district.

Historical groundwater-irrigated acres were calculated for each county by subtracting the number of surface-waterirrigated acres from the previously estimated distribution of pre-2005 total irrigated acres by year reported by the Census of Agriculture (Rich Kern, Nebraska Department of Natural Resources, written commun., 2008). Groundwater-irrigated acres were distributed within each county using the locations of active registered irrigation wells in the State of Nebraska well-registration database (Nebraska Department of Natural Resources, 2005a). Groundwater-irrigated acres per well in a county were calculated by dividing the total groundwater-irrigated acres in a county by the number of registered irrigation wells in that county. Historical estimates of groundwater- and surface-water-irrigated acres are shown in figure 5 .

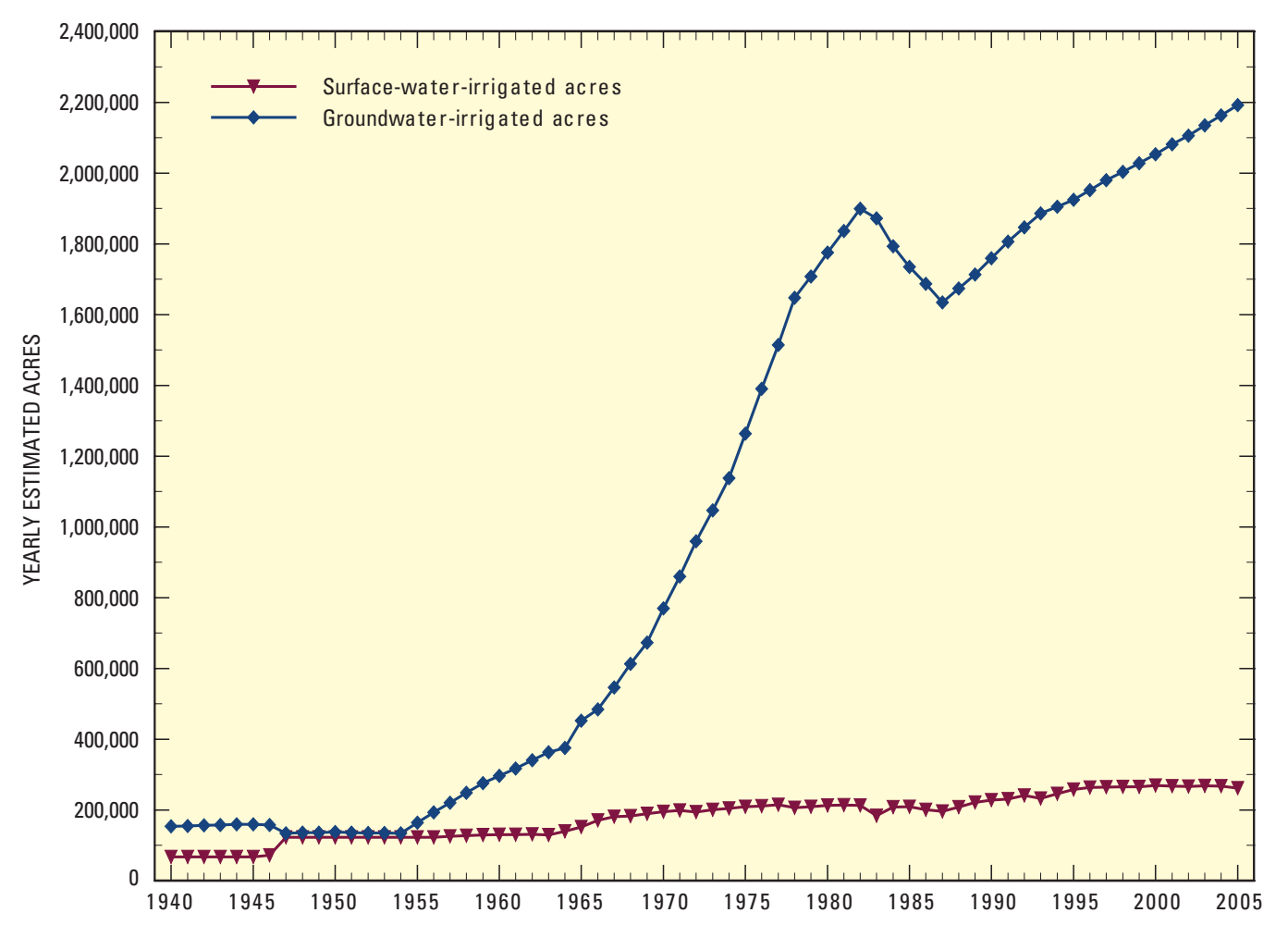

Figure 5. Yearly estimates of acres of cropland irrigated by groundwater and surface water, 1940 through 2005, Elkhorn and Loup River Basins, Nebraska. 
Pumpage for irrigation was assigned only where the results from the foregoing analysis indicated groundwater-irrigated crops were present. Crop-water requirements for each grid cell were based on the number of acres of each crop grown and the amount of water required to produce each of those crops (University of Nebraska, 1990, 2002). Individual crop-water requirements used were the same as those for the phase-one simulation: $25.5 \mathrm{inches}$ per year (in/yr) for corn, $22.0 \mathrm{in} / \mathrm{yr}$ for soybeans, $20.5 \mathrm{in} / \mathrm{yr}$ for sorghum, $15.5 \mathrm{in} / \mathrm{yr}$ for dry beans, $33.5 \mathrm{in} / \mathrm{yr}$ for alfalfa, $23.2 \mathrm{in} / \mathrm{yr}$ for potatoes, $25.0 \mathrm{in} / \mathrm{yr}$ for sugar beets, and $17.0 \mathrm{in} / \mathrm{yr}$ for small grains and sunflowers.

Estimated effective precipitation (precipitation that does not run off) was calculated for each year by adjusting growing season precipitation in each climate division (National Climatic Data Center, 2009) with Soil Conservation Service (SCS) rainfall-runoff curves (Natural Resources Conservation Service, 1986; Woodward and others, 2002). The growing season was defined to be May through September. The estimated effective precipitation for each growing season was subtracted from the water requirement of each crop to calculate the actual amount of water needed by crops that had been unmet by precipitation. When a negative value resulted, indicating that the total water requirement for that cell would have been met by effective precipitation, pumpage was set equal to zero.

Calculated crop irrigation requirement was then compared with available records of average measured pumpage during 2003 through 2007 to determine whether the estimated pumpage rates should be adjusted. Pumpage rates from 1,603 measurements in 10 counties were used to calculate average pumpage for corn, soybeans, potatoes, and alfalfa in the Lewis and Clark, Upper Elkhorn, Lower Loup, and Upper Loup NRDs (table 1). No pumpage measurements were available for the remaining six NRDs. None of the NRDs had measured pumpage data for all years from 2003 through 2007, and values were averaged using all data available within each NRD. Few or no pumpage measurements were available for dry beans, small grains, sorghum, sugar beets, or sunflowers, but these crops constituted only a small portion (5.3 percent) of the total groundwater-irrigated acres from 1940 through 2005.

To meaningfully compare measured pumpage to the estimated crop-irrigation requirement, averaged measured pumpage for each crop within a NRD was reduced by 20 percent to account for the estimated proportion of pumpage that exceeds crop-irrigation requirements and returns to groundwater as recharge. Twenty percent was used as an estimated average value based on previously published estimates of irrigation system application efficiency (Dean Eisenhauer, University of Nebraska-Lincoln, written commun., 1996). Measured pumpage minus the portion returning to groundwater is assumed to be an equivalent measure of actual irrigation requirement and is referred to as net irrigation pumpage.

The reduced measured pumpage was compared with the corresponding estimated irrigation requirement for each NRD and crop type to determine whether irrigation requirements should be adjusted (table 1). For crops with little or no measured pumpage data available, adjustments were based on corn pumpage values as a conservative approach. For NRDs with no measured pumpage data, adjustments were based on either the adjustments made in a neighboring NRD that had measured pumpage or the average of the adjustments made in other NRDs that had measured pumpage. Average annual net irrigation pumpage by county from 1940 through 2005 values are shown in figure 6 and represent an average irrigation depth in acre-inches per acre (acre-in/acre). When all crop types are averaged for a county, the irrigation depth is sometimes less than for corn or soybeans because corn and soybean fields generally have more water applied per acre than other crops.

The net irrigation pumpage for each crop was summed to yield a total net irrigation pumpage for all crops for each cell in the simulation grid. Net irrigation pumpage represents the quantity actually used by the crops or evaporated. Actual pumpage is larger than net pumpage because some of the pumped water returns to the groundwater system as recharge. It was assumed that pumped water not used by crops or lost to evaporation became aquifer recharge within the same stress period as the simulated pumpage occurred.

Although the proportion of total measured pumpage that returns to groundwater was important for estimating net irrigation pumpage, it is difficult to quantify and likely varies across the study area. Irrigation system application inefficiency estimates range from 10 to 65 percent and depend upon a number of factors including type of irrigation system, soil type, application practices, and crop field slope (Dean Eisenhauer, University of Nebraska-Lincoln, written commun., 1996). Also, inefficiency estimates represent the total amount of pumped water not available for crop use, instead of just the amount lost to aquifer recharge. In addition, pumpage measurements were not distributed evenly in the study area; most measurements were from four counties. Therefore, it is uncertain whether the adjusted pumpage values are truly representative of average conditions within each NRD; however, these were the best data available at the time of simulation construction.

Final pumpage values applied to the simulation combined net irrigation pumpage and pumpage for municipal water supplies. The amount of pumpage for municipal water supplies was obtained from the measured pumpage reported by municipalities in the study area (Shuhai Zheng, Nebraska Department of Natural Resources, written commun., 2007). Most of the reported municipal pumpage data were from 2004; however, some values were from 2001 to 2003 or 2005 . The reported municipal pumpage rates were applied as a constant value to all years in the simulated 1940 through 2005 period. This approach assumes that historical pumpage for municipal water use can be represented by pumpage during recent years. This assumption may not be realistic, but because pumpage for municipal supplies is a small proportion of total pumpage (about 3 percent), this approach provided a reasonable approximation for a regional groundwater-flow simulation.

Total municipal-plus-net-irrigation pumpage was about 60 percent greater than values used in the phase-one simulation. This difference is mostly attributed to the availability of 
Table 1. Location of pumpage measurements, average measured pumpage, and adjustments made to crop irrigation requirement, Elkhorn and Loup River Basins, Nebraska.

[NA, not available]

\begin{tabular}{|c|c|c|c|c|c|}
\hline Natural Resources District(s) & \multicolumn{2}{|c|}{ County } & & \multicolumn{2}{|c|}{$\begin{array}{l}\text { Number of pumpage } \\
\text { measurements }\end{array}$} \\
\hline Lewis and Clark ${ }^{1}$ & \multicolumn{2}{|c|}{ Knox } & & \multicolumn{2}{|c|}{76} \\
\hline \multirow[b]{2}{*}{ Lower Loup ${ }^{3}$} & \multicolumn{2}{|c|}{ Holt } & & \multicolumn{2}{|c|}{395} \\
\hline & \multicolumn{2}{|c|}{ Nance } & & \multicolumn{2}{|c|}{317} \\
\hline \multirow{4}{*}{ Upper Loup ${ }^{4}$} & \multicolumn{2}{|c|}{ Grant } & & \multicolumn{2}{|c|}{3} \\
\hline & \multicolumn{2}{|c|}{ Logan } & & \multicolumn{2}{|c|}{52} \\
\hline & \multicolumn{2}{|c|}{ McPherson } & & \multicolumn{2}{|c|}{1} \\
\hline & \multicolumn{2}{|c|}{ Thomas } & & \multicolumn{2}{|c|}{2} \\
\hline Natural Resources District(s) & Corn & Soybeans & Potatoes $^{5}$ & Alfalfa $^{6}$ & All other crops ${ }^{7}$ \\
\hline & \multicolumn{5}{|c|}{ Average measured pumpage, in inches per year } \\
\hline Lewis and Clark ${ }^{1}$ & 10.55 & 8.65 & NA & 10.00 & NA \\
\hline Upper Elkhorn ${ }^{2}$ & 15.96 & 15.81 & 18.00 & NA & NA \\
\hline Lower Loup ${ }^{3}$ & 12.85 & 10.28 & 12.00 & NA & NA \\
\hline \multirow[t]{2}{*}{ Upper Loup ${ }^{4}$} & 14.25 & 9.28 & NA & 11.00 & NA \\
\hline & \multicolumn{5}{|c|}{$\begin{array}{c}\text { Adjustment to crop irrigation requirement, in inches per year (numbers indicate amount added to } \\
\text { crop irrigation requirement) }\end{array}$} \\
\hline $\begin{array}{l}\text { Lewis and Clark, Lower Elkhorn, and } \\
\text { Lower Platte North }\end{array}$ & 0.13 & 2.12 & 4.49 & -8.09 & 0.13 \\
\hline
\end{tabular}

${ }^{1}$ Source: Terry Julesgard, Lewis and Clark Natural Resources District, written commun., 2007.

${ }^{2}$ Source: Tylr Naprstek, Upper Elkhorn Natural Resources District, written commun., 2007.

${ }^{3}$ Source: Russ Callan, Lower Loup Natural Resources District, written commun., 2007.

${ }^{4}$ Source: Jack Brummet, Upper Loup Natural Resources District, written commun., 2007.

${ }^{5}$ Pumpage for potatoes only reported in the Lower Loup and Upper Elkhorn Natural Resources Districts.

${ }^{6}$ Pumpage for alfalfa only reported in the Lewis and Clark and Upper Loup Natural Resources Districts.

${ }^{7}$ Estimated using measured pumpage for corn. 


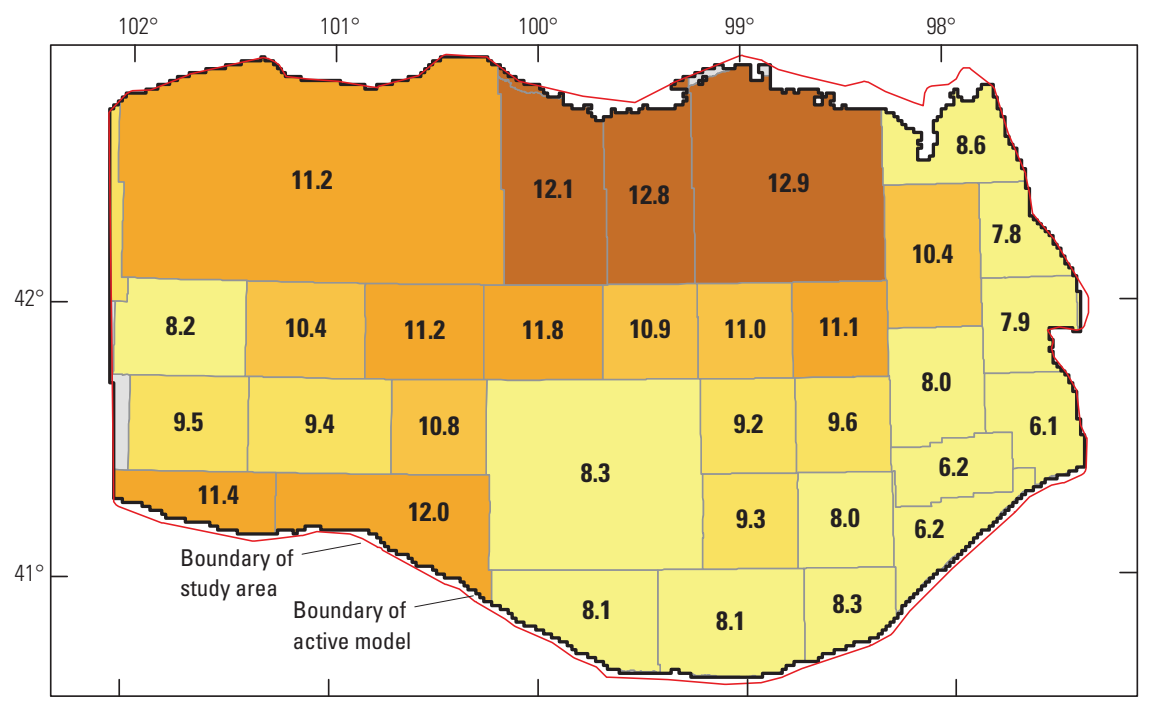

\section{EXPLANATION}

Average annual net irrigation pumpage for all crops, 1940 through 2005 , in acre-inches/acre 9.0 or less

9.0 to 10.0

10.0 to 11.0

11.0 to 12.0

12.0 to 13.0

13.0 to 14.0

More than 14.0

No crops reported

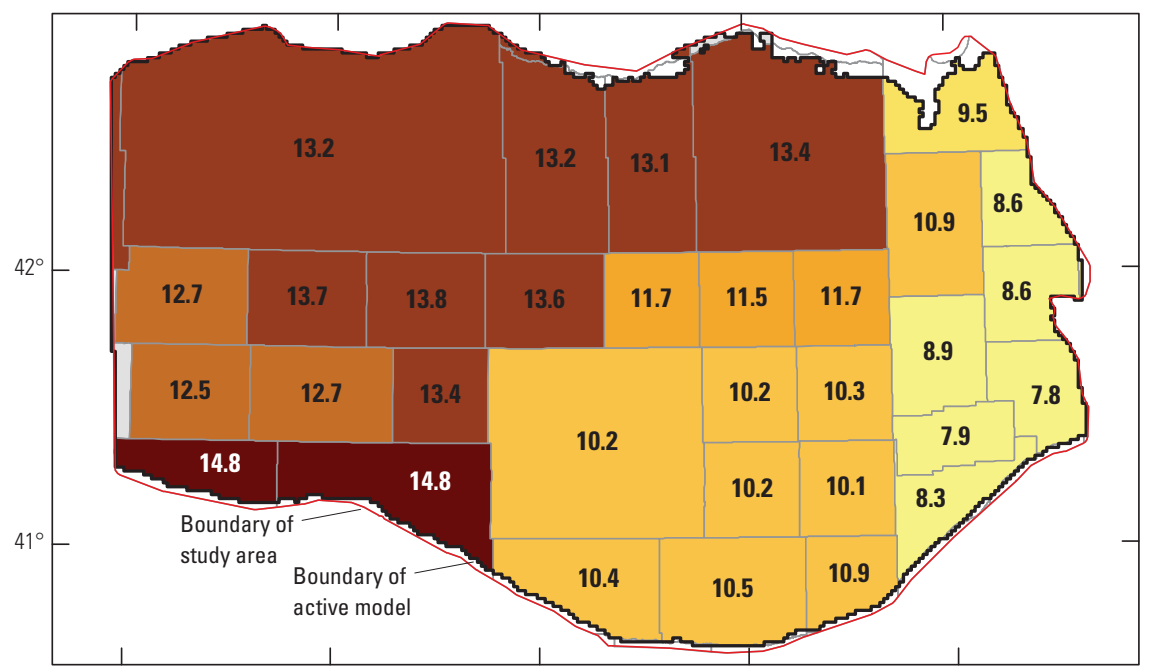

\section{EXPLANATION}

Average annual net irrigation pumpage for corn, 1940 through 2005 ,

in acre-inches/acre

9.0 or less

9.0 to 10.0

10.0 to 11.0

11.0 to 12.0

12.0 to 13.0

13.0 to 14.0

More than 14.0

No crops reported

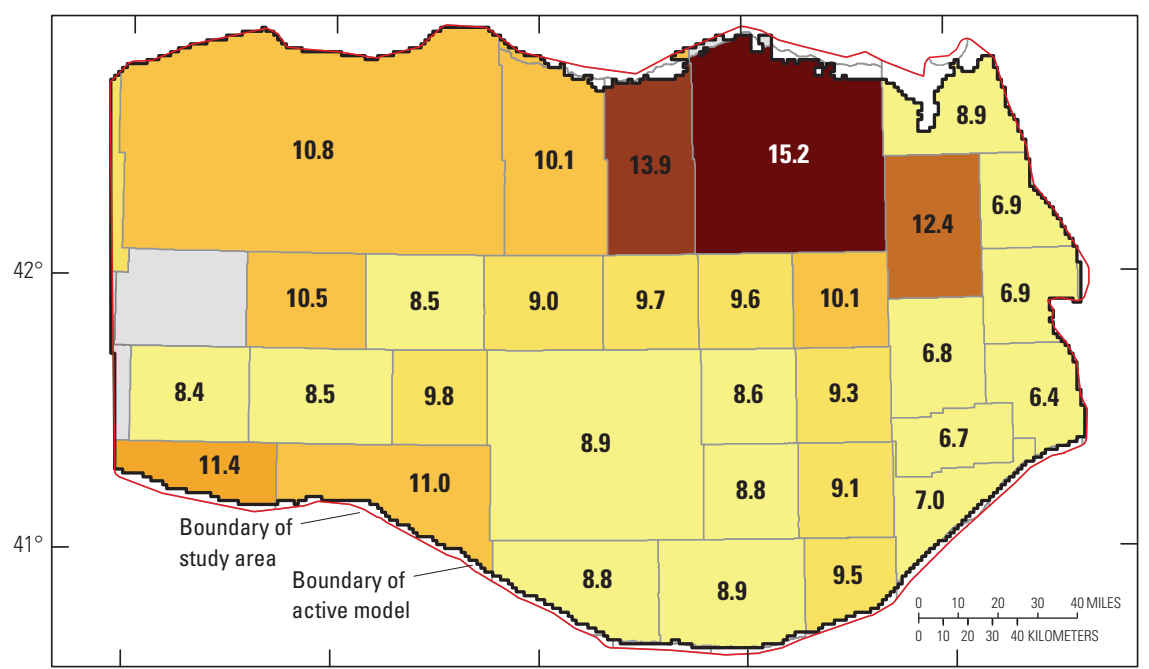

\section{EXPLANATION}

Average annual net irrigation pumpage for soybeans, 1940 through 2005 , in acre-inches/acre

9.0 or less

9.0 to 10.0

10.0 to 11.0

11.0 to 12.0

12.0 to 13.0

13.0 to 14.0

More than 14.0

No crops reported

Figure 6. Average annual net irrigation pumpage by county, 1940 through 2005, Elkhorn and Loup River Basins, Nebraska. 
additional pumpage measurements with which to adjust estimates of crop-irrigation requirements. Pumpage measurements available for the phase-one simulation indicated that crop-irrigation requirements needed to be reduced by more than $3 \mathrm{in} /$ yr; whereas pumpage measurements available for the phasetwo simulation indicated that crop-irrigation requirements for crops other than alfalfa typically needed to be increased by 1 to $4 \mathrm{in} / \mathrm{yr}$, and by as much as $7.67 \mathrm{in} / \mathrm{yr}$ for soybeans in two NRDs (table 1). Total simulated pumpage for each county in 2000 was calculated and compared with estimated total groundwater use in 2000 (Hutson and others, 2004) to verify that pumpage values were reasonable (fig. 7). In that report, groundwater withdrawals for irrigation were calculated as potential evapotranspiration minus effective precipitation (James Parnell, U.S. Geological Survey, written commun., 2003) and should, therefore, be comparable to net irrigation pumpage values used in this report. In most counties, calculated total municipal-plus-net-irrigation pumpage was close to published estimated groundwater use. In general, simulated pumpage was less than what was estimated by Hutson and others (2004). Of the 23 counties used in the comparison (counties that were almost entirely within the ELM study area), only Holt and Greeley Counties had more simulated pumpage than was estimated.

\section{Recharge}

Recharge in the simulation was composed of recharge from precipitation, additional recharge beneath agricultural land, and additional recharge from canal seepage. Recharge from precipitation was applied to every grid cell. Where irrigated and nonirrigated cropland was present, additional recharge was added to recharge from precipitation to calculate a total recharge. Canal seepage recharge was applied uniformly to any grid cell coinciding with a canal, canal lateral, or land that received canal water for irrigation and was added to recharge from precipitation and additional recharge beneath agricultural land if present.

\section{Recharge from Precipitation}

Recharge from precipitation was the largest source of water to the simulation. Values were assigned as part of the calibration process and were allowed to vary spatially and temporally. Spatial variation was implemented by dividing the study area into 20 recharge zones that were defined primarily by surface-water drainage basins (fig. 8). These zones coincided with boundaries of previously published runoffrecharge watershed models developed to help constrain rates of recharge from precipitation (Strauch and Linard, 2009). Areas closer to the edge of the study area were not included in the watershed models because these areas were not within the Elkhorn and Loup River drainage basins. These areas were divided into separate zones by climate division boundaries (National Climatic Data Center, 2009) in the south and by general topographic characteristics and precipitation patterns in the north.

For the pre-1940 period, recharge values representing long-term average conditions before groundwater development were assigned to the 20 recharge zones. Each zone was assigned a specific rate of annual recharge that did not change with time during the pre-1940 period. Initial values were set equal to the average values obtained from the watershed models. During the manual calibration process, the initial average values were reduced until the simulated groundwater levels best reproduced measured pre-1940 groundwater levels, while maintaining the general patterns exhibited by the watershed models. Recharge was further adjusted during the automated calibration phase and constrained to between 0 and $20 \mathrm{in} / \mathrm{yr}$ (appendix 2). Final calibrated pre-1940 recharge from precipitation values ranged from 0.5 to $5.0 \mathrm{in} / \mathrm{yr}$ (fig. 8).

For the manual calibration of the 1940 through 2005 period, recharge from precipitation values did not change with time because the increase in the number of parameters to be tested would have made manual calibration impractical. Temporal variation in recharge rates during 1940 through 2005 was introduced during the automated calibration process by partitioning each of the 20 recharge zones into 4 to 9 time periods. Time periods were based on temporal differences in recharge patterns noted in results from the watershed models. This resulted in 135 independently controllable recharge values distributed through time and space. The discretization of time into multi-year periods for each area was a compromise between using average recharge from precipitation (time invariant) for the entire simulation, as was used for the phaseone simulation, and using values that were allowed to change annually. The former case would not adequately represent the short-term dynamics of the system to account for the changes in groundwater levels and base flow with time, whereas the latter would result in excessive computational time. Further, there is an upper limit to the number of parameters that can be uniquely estimated from limited calibration targets. If the number of parameters exceeds the information contained in the calibration targets, spurious parameter values can be obtained (Hill and Tiedeman, 2007), so consolidating the timevarying parameters into groups, based on known characteristics of the system dynamics, minimized this behavior. Final average calibrated values of recharge from precipitation for the 1940 through 2005 period ranged from 1.0 to $4.5 \mathrm{in} / \mathrm{yr}$ (fig. 8).

Average calibrated values were consistent with expectations of spatial variation across the study area. The Sand Hills region had the largest rates, and the dissected Loess Plains (Peterson and others, 2008) had the smallest recharge rates. Previous conceptualization of groundwater recharge in the phase-one simulation defined an upper limit for recharge from precipitation of about $3 \mathrm{in} / \mathrm{yr}$; however, soil-moisture models and watershed models (Dugan and Zelt, 2000; Strauch and Linard, 2009) indicated that recharge could be greater than $3 \mathrm{in} / \mathrm{yr}$ in many parts of the study area. 


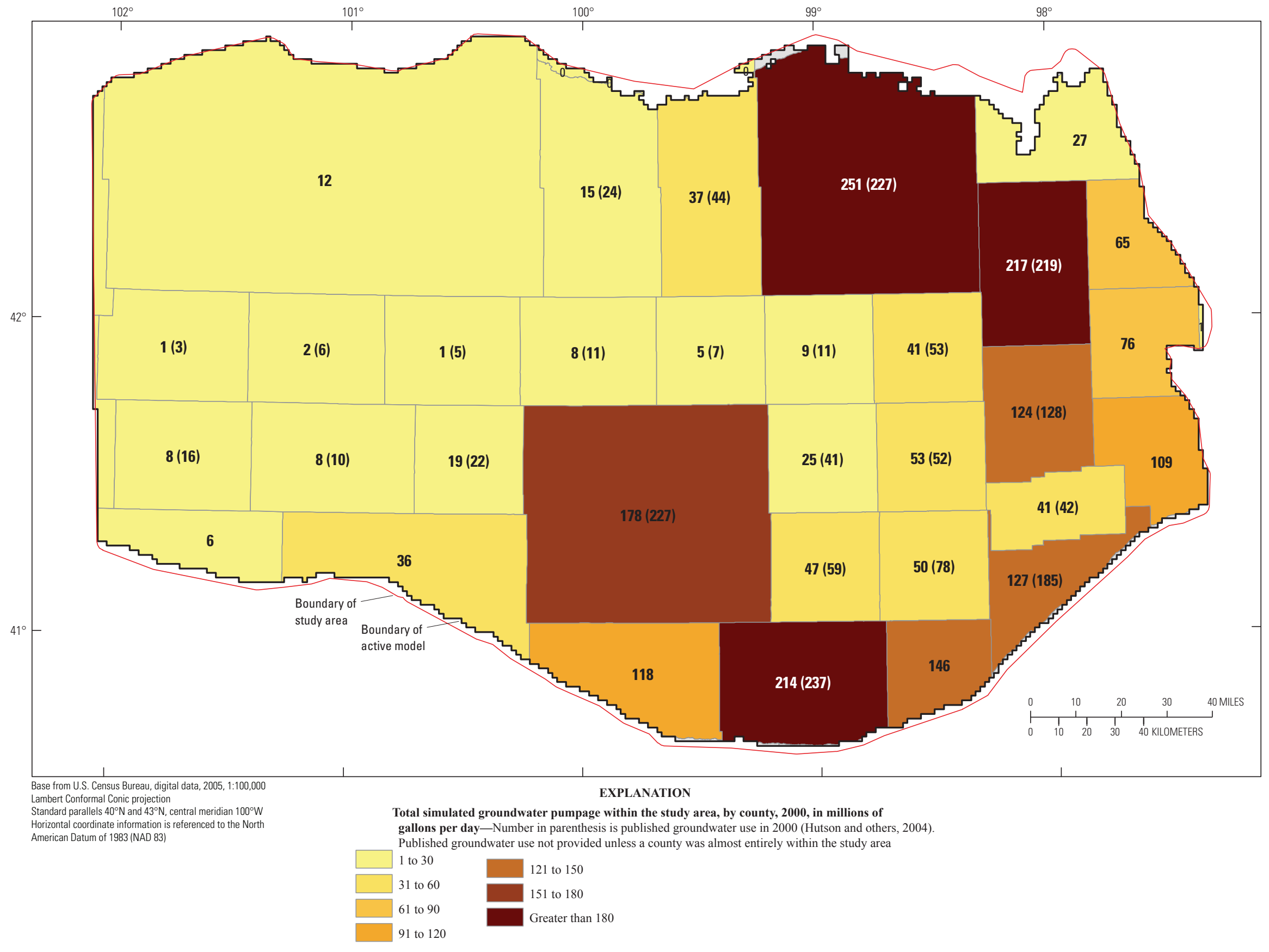

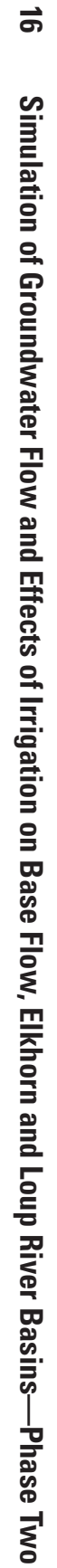

Figure 7. Total simulated groundwater pumpage and estimated total groundwater use, by county, 2000, Elkhorn and Loup River Basins, Nebraska. 


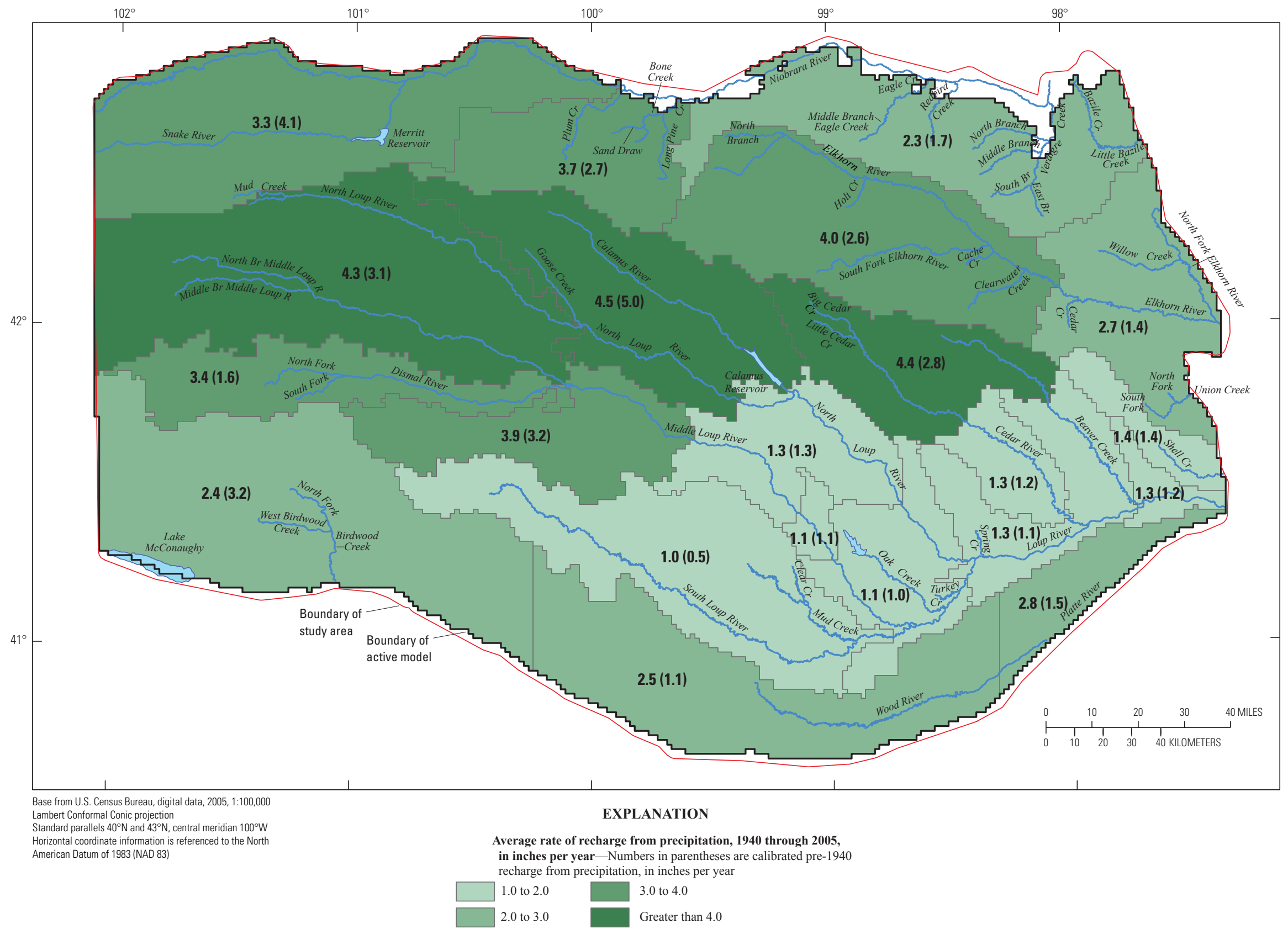

Figure 8. Calibrated recharge from precipitation, Elkhorn and Loup River Basins, Nebraska. 


\section{Additional Recharge Beneath Agricultural Land}

In addition to the general recharge from precipitation, the simulations applied a supplemental amount of recharge for model cells covered by agricultural cropland. This concept of recharge is similar to that reported by Scanlon and others (2005): that recharge rates are lowest in natural rangeland areas, moderate in nonirrigated cropland areas, and moderateto-high in irrigated cropland areas. Lands that have been tilled allow precipitation to infiltrate more easily than those areas that remain rangeland. Similarly, the practice of irrigation increases soil moisture and enhances recharge (McMahon and others, 2006). Therefore, it was inferred that areas with nonirrigated crops allow more recharge than rangeland, and areas with irrigated crops allow more recharge than areas with nonirrigated crops.

The rate of additional simulated recharge assigned to irrigated- and nonirrigated-cropland classes in the simulation was invariant for the 1940 through 2005 period, though the total amount of recharge did change with time because the amount of land classified as irrigated cropland, nonirrigated cropland, and rangeland changed. Additional recharge applied to irrigated and nonirrigated cropland, in excess of recharge from precipitation, was originally implemented using calibrated parameters; however, the optimal irrigated-land recharge supplements were as much as $9 \mathrm{in} / \mathrm{yr}$ during manual calibration and $7.8 \mathrm{in} / \mathrm{yr}$ during automated calibration. These values were deemed too large as compared with estimated net irrigation pumpage values (Elkhorn-Loup Model Technical Committee, oral commun., 2009). In some areas, these calibrated additions were larger than average net irrigation pumpage values (fig. 6); therefore, previously published values were used. Although a regional assessment comparing recharge on rangeland, nonirrigated cropland, and irrigated cropland is not available for the study area, several site-specific studies completed in the northern High Plains provided guidance for estimating recharge on irrigated agricultural areas. Dugan and Zelt (2000) compared deep percolation for irrigated and all nonirrigated lands (including rangeland) for several soil and crop types near Kearney, Nebr. (inset, fig. 1), from 1951 through 1980. They reported that recharge for irrigated cropland was between 0.13 and $0.30 \mathrm{in} / \mathrm{yr}$ greater than for nonirrigated cropland (0.60 to $6.65 \mathrm{in} / \mathrm{yr}$ ). McMahon and others (2006) compared unsaturated-zone recharge rates for two irrigated sites and one rangeland site in southwestern Nebraska and northeastern Colorado and determined that the two irrigated sites had 1.3 and $1.6 \mathrm{in} / \mathrm{yr}$ greater recharge than the rangeland site $(2.76 \mathrm{in} / \mathrm{yr})$. The results of these two site-specific studies may not be representative of regional conditions in the ELM study area, but in the absence of regional data, provide the best information available. Based on those two studies, irrigated cropland areas were assigned $1.0 \mathrm{in} / \mathrm{yr}$ additional recharge, a value that was slightly larger than the average of the values published by these two studies. This is a smaller value than the $3.5 \mathrm{in} / \mathrm{yr}$ used for the phase-one simulation, but it is likely that in the phase-one simulation the additional recharge applied to irrigated cropland was, in part, compensating for recharge from precipitation values that did not change over time.

The optimal calibrated nonirrigated-cropland recharge added to recharge from precipitation was $0.5 \mathrm{in} / \mathrm{yr}$ for the 1940 through 2005 period for the manual and automated calibrations, as it was for the phase-one simulation; therefore, $0.5 \mathrm{in} / \mathrm{yr}$ was considered to be a reasonable estimate. In rangeland areas, no additional recharge was applied, and total recharge was equal to recharge from precipitation.

\section{Additional Recharge from Canal Seepage}

Canals were not explicitly simulated as part of the streams network but recharge from canal seepage was included in the simulation. Recharge from canal seepage represents the amount of canal water lost through canal-bed leakage. Recharge from leakage of the Cozad, Dawson, Elm Creek, Gothenburg, and Kearney Canal Systems (fig. 9) was simulated during the pre-1940 period. Cozad, Dawson, Gothenburg, and Kearney Canal Systems began operation around 1895. The Elm Creek Canal System began operation in 1929. Because measurements of neither canal seepage nor water delivered to fields were available for these canal systems, recharge from canal seepage was estimated to be 43 percent of the yearly water diverted from the Platte River, minus any water returned back to the Platte River, based on previous work (Duane Woodward, Central Platte Natural Resources District, oral commun., 2002). Seepage recharge was applied uniformly to any grid cell coinciding with a canal, canal lateral, or land that received canal water for irrigation. Recharge from canal seepage does not include enhanced recharge that may occur because of over irrigation, that is, the application of surface water in excess of crop irrigation requirement.

In addition to the five canal systems in operation during the pre-1940 period, seven irrigation districts began operating new canal systems during the 1940 through 2005 period. The Birdwood Irrigation District started diverting water in 1946, Middle Loup Public Power and Irrigation District and North Loup Irrigation District started in 1947, Sargent Irrigation District started in 1957, Farwell Irrigation District started in 1963, Ainsworth Irrigation District started in 1965, and the Twin Loups Irrigation District started in 1987 (fig. 9). The only canal system that ceased operation during 1940-2005 was Elm Creek Canal (in 1962).

Calculated annual canal and lateral losses (canal seepage) based on water-mass balance were available for at least part of the 1940 through 2005 period for Middle Loup (Allan Schmidt, Middle Loup Public Power and Irrigation District, written commun., 2006), Sargent (Mel Brozek, Sargent Irrigation District, written commun., 2006), Farwell (Jack Wergen, Bureau of Reclamation, written commun., 2006, and Darwin Lee, Farwell Irrigation District, written commun., 2006), Ainsworth (William Peck, Bureau of Reclamation, written commun., 2006), and Twin Loups (Ron Wolf, Twin Loups Irrigation District, written commun., 2006) Irrigation Districts. Recharge from canal seepage in an irrigation district 


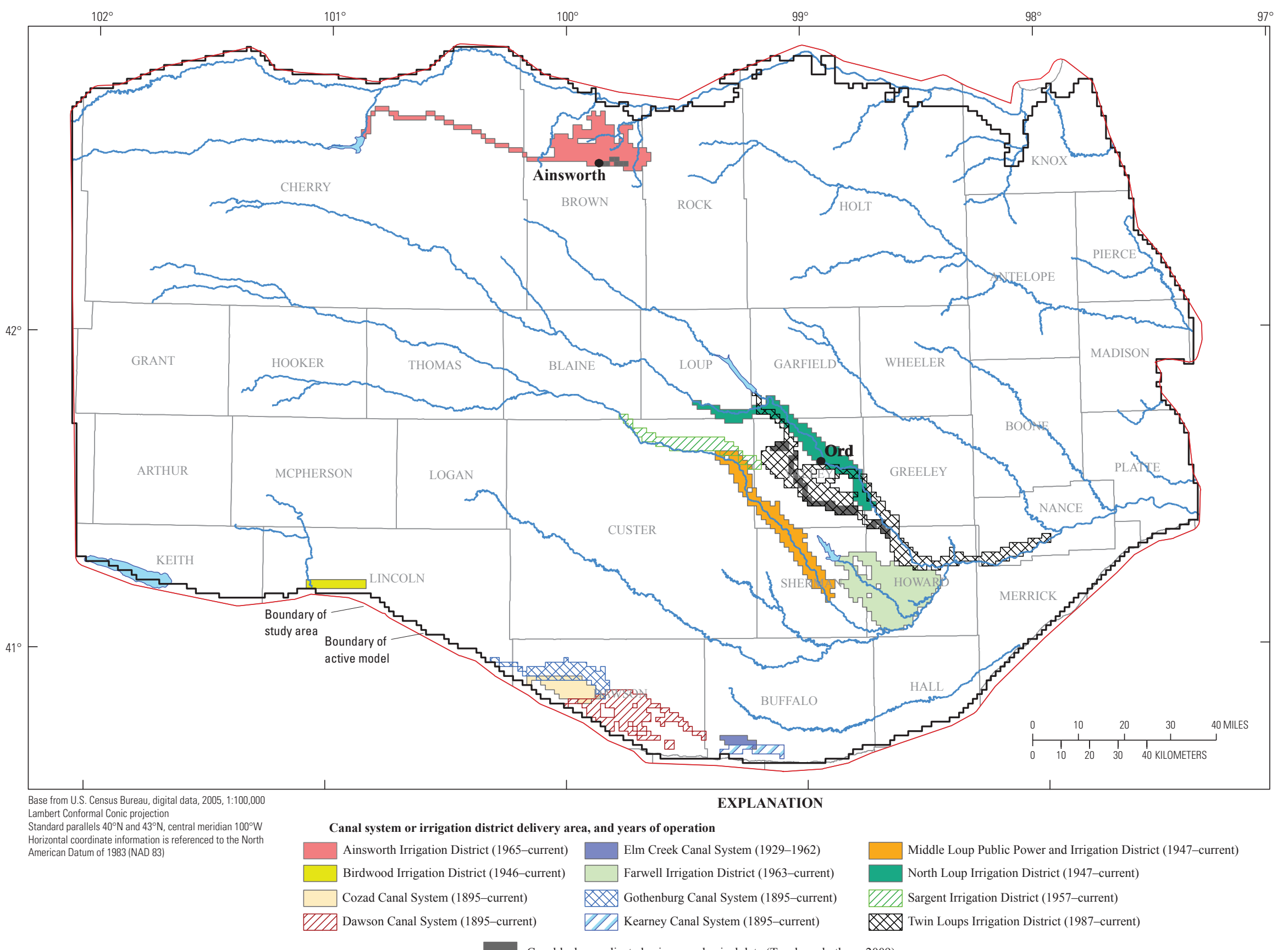

Figure 9. Canal systems and irrigation districts in and near the Elkhorn and Loup River Basins, Nebraska. 
was applied uniformly to all grid cells within that irrigation district (fig. 9). Canal-seepage recharge was applied to a total of 1,380 grid cells, or about 5 percent of the active simulation area.

Geophysical data obtained from frequency-domain electromagnetic continuous-resistivity profiles provided additional information about the relative potential for interaction between surface water and groundwater along parts of the Ainsworth Canal near Ainsworth, Nebr., and the Mirdan and Geranium Canals near Ord, Nebr., (Teeple and others, 2009). The relative interaction potentials were estimated from apparent resistivity data by dividing the minimum apparent resistivity at each point along a canal by the greatest minimum apparent resistivity from all such points along four survey profiles in the study area. Resulting relative interaction potentials were averaged over each ELM grid cell coinciding with geophysical data collection. Seepage recharge values were then adjusted such that grid cells with a greater relative potential for interaction had larger recharge values, and cells with less relative potential for interaction had smaller recharge values. The average recharge value of the adjusted cells remained unchanged.

\section{Comparison with Watershed Model Recharge}

A number of approaches are available for estimating groundwater recharge and can be categorized as water budget, unsaturated zone, groundwater, streamflow, or tracer methods (U.S. Geological Survey, 2009). Each method is subject to uncertainties, and therefore, the use of multiple methods can improve the reliability of recharge estimates (Scanlon and others, 2002).

Total calibrated recharge from the ELM simulation was compared with estimated recharge from runoff-recharge watershed models developed using the Soil and Water Assessment Tool (SWAT) as part of the phase-two study (Strauch and Linard, 2009). Areas where calibrated ELM recharge was most similar to watershed-model recharge estimates were the Plum and Long Pine Creek Basins, the upper and lower Elkhorn River Basins, and the middle sections of the Middle and North Loup Rivers. Simulated ELM recharge did not match year-toyear variability of the watershed-model recharge nor was it expected to, because simulated ELM recharge was not allowed to change for every year in the ELM.

In many parts of the Loup Basin, recharge values from watershed models were larger than calibrated recharge values. Differences between the recharge obtained from the watershed models and simulated recharge in the ELM could be a result of several factors. In the Sand Hills specifically, the watershed models did not simulate accurately the response of the hydrologic system to precipitation, and therefore, recharge was overestimated. Also, method characteristics could have caused differences in recharge estimates. Recharge values from the watershed models were derived from a streamflowbased method and thus were calculated as potential recharge, that is, water that is available for but may not actually become recharge either because of processes in the unsaturated zone or the capacity of the saturated zone to accept recharge (Scanlon and others, 2002). Calibrated recharge from the ELM simulation was from a groundwater-based method and was calculated as actual recharge, that is, infiltrating water that reaches the water table (Scanlon and others, 2002). Finally, the watershed models were not coupled with the groundwater-flow simulation, nor was there coupling of the ELM to the SWAT models, and feedback was not provided between hydrologic processes at the land surface and processes in the subsurface during calibration of either type of simulation. Use of simulation software that couples groundwater and surface-water processes, such as GSFLOW (Markstrom and others, 2008) or MODFLOW's Farm Process (Schmid and others, 2006), may have improved the calibrated recharge results from the groundwater-flow simulation, but neither was part of the scope of the phase-two study.

\section{Evapotranspiration}

Simulated evapotranspiration (ET) was used to represent the sum of transpiration of groundwater directly by plants and evaporation of groundwater near land surface or where groundwater intersects the land surface, such as wetlands, lakes, and streams. Phreatophytic plants in the study area include cottonwood, willow, and grasses (Landon and others, 2009; Bleed and Flowerday, 1989). Simulated ET for this report is specific to groundwater and should not be confused with ET of soil moisture. In some areas, ET can remove large amounts of groundwater at or near land surface; therefore, ET was included in the groundwater-flow simulation (Harbaugh, 2005). Simulated ET removes groundwater at a specified maximum rate when the simulated groundwater level is at or above a specified threshold, or "ET elevation," usually assigned as equal to land-surface elevation. An extinction depth also is specified, and when the simulated groundwater level is at or below this depth, simulated ET does not remove any groundwater from the simulation. Between the specified ET elevation and the extinction depth, the rate at which water is removed varies linearly between the maximum rate and zero.

Simulated ET was specified to occur from grid cells having at least 20 acres of open water, wetlands, or riparian woodlands as reported in the 2005 land-use map (Center for Advanced Land Management Information Technologies, 2007). In total, 9,699 grid cells, or about 33 percent of the active simulation area, satisfied this criterion. Simulated ET also was specified to occur from any grid cell that contained a simulated stream.

ET rates were expected to vary because of climatic conditions across the study area. Lake evaporation contours (U.S. Weather Bureau, 1959) indicate that rates are largest in the south (about $50 \mathrm{in} / \mathrm{yr}$ ) and decrease to about $39 \mathrm{in} / \mathrm{yr}$ in the northeast. The mapped lake evaporation was used in conjunction with measured rates of ET from groundwater at the Odessa, Nebr., ET monitoring station (Landon and others, 2009) to generate initial maximum ET rates for the simulation. Annual ET rates at the monitoring station ranged from about 
20 to 23 inches, and annual ET rates from groundwater were estimated to range from 0 to 20 inches. These rates are smaller than lake evaporation values because they are a measure of the amount of water actually lost to ET, rather than the total potential ET. Several settings of maximum ET rates were then tested during the manual calibration process. The values that resulted in the best reproduction of pre-1940 groundwater levels were similar to the calibrated values from the phase-one simulation, ranging from more than $16 \mathrm{in} / \mathrm{yr}$ in the south (near Odessa) to less than $5 \mathrm{in} / \mathrm{yr}$ in the northeastern part of the ELM area (fig. 10).

The specified ET elevation for each active ET grid cell was set to the $25^{\text {th }}$ percentile of the land-surface elevation values within that grid cell. Land-surface elevation values were obtained from a digital elevation model having 32.8-ft (10-meter) resolution (Nebraska Department of Natural Resources in workshare agreement with the U.S. Geological Survey, 1998). The $25^{\text {th }}$ percentile of land-surface elevations was used because groundwater is most likely to be near the land surface at lower elevations. The extinction depth was set to $5 \mathrm{ft}$. Although small amounts of groundwater may be removed from the aquifer at depths greater than $5 \mathrm{ft}$, most ET is thought to occur within several feet of the land surface and, therefore, $5 \mathrm{ft}$ was considered reasonable as the maximum depth for simulated ET of groundwater.

\section{Lakebed Seepage for Lake McConaughy}

The only reservoir included in the simulation was Lake McConaughy. Although this reservoir is located in the far southwestern corner of the study area and is not important to groundwater-flow processes in the Elkhorn or Loup River Basins, it was included because the presence of the lake had the potential to affect simulated groundwater levels, stageelevation data were readily available, and it was the largest reservoir within the study area. A general-head boundary was used to simulate Lake McConaughy for 1940 through 2005 (fig. 2). General-head boundaries are similar to fixed-waterlevel boundaries, except that the interaction of the boundary with the simulated groundwater system also is controlled by a hydraulic conductance term that includes the area, thickness, and hydraulic conductivity of bed sediments (Harbaugh, 2005). General-head boundaries commonly are used to simulate lakes and reservoirs, although, as with fixed-water-level boundaries, care must be taken to ensure that the groundwater flow to and from the general-head boundary is realistic.

Lake McConaughy began storing water in 1940, reaching average storage capacity by about 1947 (C. Steinke, Central Nebraska Public Power and Irrigation District, written commun., 2007). Simulated groundwater-level elevations from the end of the pre-1940 period were used as the starting lake-stage elevations for the general-head boundary, as they were in the rest of the simulation domain. Thereafter, annual lake-stage elevations were assigned to the simulated 1940 through 2005 general-head boundary if the lake-stage elevation in any given general-head boundary cell was higher than the simulated
1940 groundwater-level elevation. Lake-stage elevation was set to the simulated groundwater-level elevation in 1940 when the measured lake-stage elevation after 1940 was lower than that groundwater-level elevation.

\section{Calibration}

Calibration is the process of evaluating simulation results during a historical period to establish that a simulation can reproduce actual hydrogeologic conditions in the area of interest. Calibration targets are hydrologic measurements to which simulation results are compared. These targets are used in the calibration process to guide adjustment of aquifer-system properties (parameters) for "fine tuning" the simulation.

\section{Calibration Targets}

Three types of calibration targets were used, and each type is described in the following subsections of the report. Not all types of targets were used for both calibrated periods of simulation, that is, pre-1940 and 1940 through 2005.

\section{Groundwater-Level Targets Used During the Pre-1940 Period}

Simulated results of the pre-1895 period were not compared to calibration targets because an inadequate number of measurements with known levels of accuracy and uncertainty exist. Simulated 1895 groundwater levels were used as starting groundwater levels for the 1895 through 1940 period, and 1939 simulation results were compared with measured groundwater levels and estimated base flows. Groundwater-level targets were obtained from the USGS National Water Information System (U.S. Geological Survey, 2005). Groundwater-level measurements generally were not widely made during the pre-1940 period; therefore, groundwater-level targets used for calibrating this simulation were the earliest available measurements considered to record groundwater levels unaffected by groundwater irrigation (Peterson and others, 2008).

The final set of 506 groundwater-level targets (fig. 11) was collected during spring months between 1928 and 2002, with a mean collection year of 1959. The distribution of these groundwater-level measurements was fairly consistent across the study area, though a larger number of measurements were located in the south. Most groundwater-level target data that had been collected in later decades, that is, from 1980 to 2002, were from Arthur and McPherson Counties, which were still mostly undeveloped for agriculture in 2005.

\section{Groundwater-Level-Change Targets Used During the 1940 through 2005 Period}

Decadal groundwater-level changes were used to calibrate the 1940 through 2005 period. The uncertainty and misfit between simulated and measured groundwater levels at the end of 1939 probably would bias a comparison of 


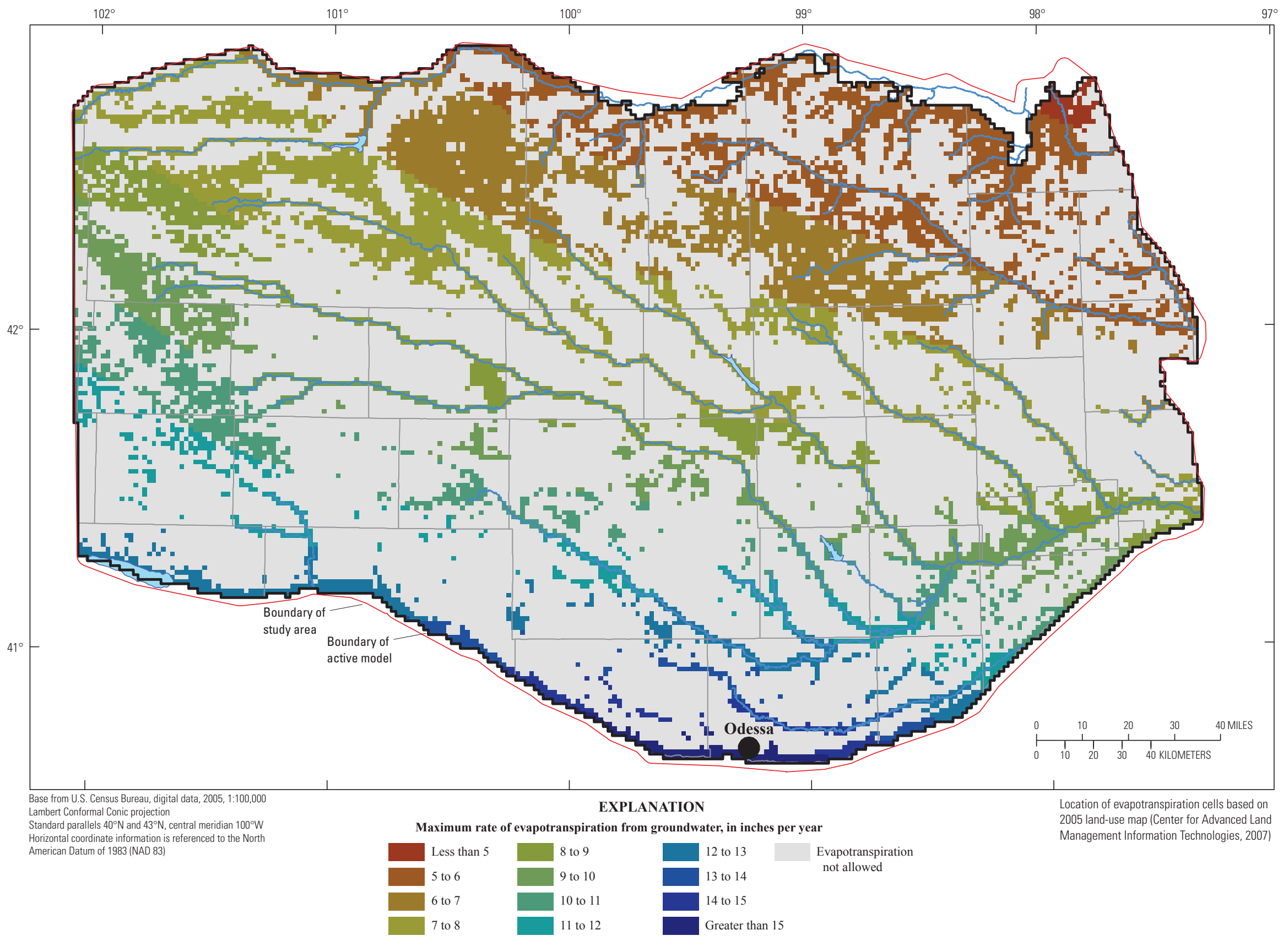

Figure 10. Calibrated maximum rate of evapotranspiration (ET) from groundwater, Elkhorn and Loup River Basins, Nebraska. 


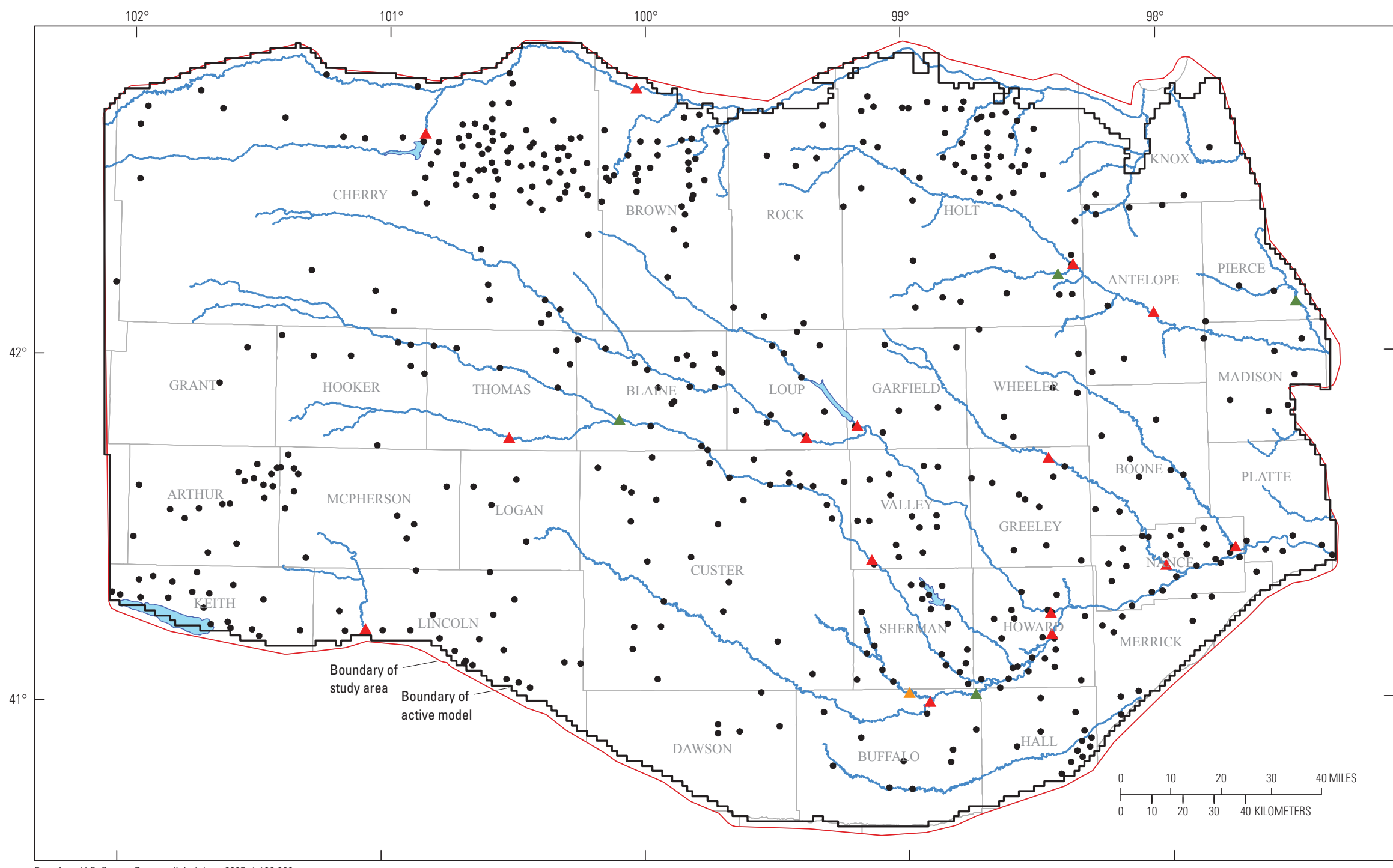

Base from U.S. Census Bureau, digital data, 2005, 1:100,000 Lambert Conformal Conic projection
Standard parallels $50^{\circ} \mathrm{N}$ and $43^{\circ} \mathrm{N}$, central meridian $100^{\circ} \mathrm{W}$ Horizontal coordinate information is referenced to the North

EXPLANATION

Horizontal coordinate information is
American Datum of 1983 (NAD 83)

- Location of groundwater-level measurements used to calibrate the pre-1940 period

- Streamflow-gaging station for which base flow was estimated from median of annual values over the period of record, and used in calibration

A Streamflow-gaging station for which base flow was estimated using base-flow trends early in the period of record, and used in calibration

A Streamflow-gaging station for which base flow was estimated as the average of the minimum and maximum annual base-flow values, and used in calibration

Figure 11. Distribution of groundwater-level measurements and base-flow observations used to calibrate simulation of the pre-1940 period, Elkhorn and Loup River Basins, Nebraska. 
absolute groundwater levels simulated from 1940 through 2005 to measured groundwater levels. For example, simulated recharge during the 1940 through 2005 period may be biased high to compensate for simulated groundwater-levels that are too low in 1939; therefore, groundwater-level changes were used as the calibration targets because they provided a clearer indication of simulation calibration to conditions for the 1940 through 2005 period only (and for various intermediate periods), rather than potentially being affected by errors that may have been present in the simulated groundwater levels from the pre-1940 period.

Groundwater-level changes generally were calculated from measured groundwater levels in 10-year increments (1945-55, 1955-65, 1965-75, 1975-85, 1985-95, and 1995-2005). To obtain the largest number of calibration targets, measured groundwater levels were selected separately by decade from all available groundwater-level measurements, even if a measurement was not specifically available during $1945,1955,1965,1975,1985,1995$, and 2005. For example, to calculate 1945-55 groundwater-level change, a well optimally would have a measured groundwater level representing both 1945 and 1955, but wells were not always measured in those specific years; therefore, the measurement representing 1945 could be a measurement made between 1940 and 1949 in the year closest to 1945, and the measurement representing 1955 could be a measurement made between 1950 and 1959 in the year closest to 1955. Because more measurements were available in later years, more groundwater-level-change targets for recent decades were calculated using groundwater levels measured in the optimal years. For the 1995 to 2005 groundwater-level-change period, 93 percent of the targets used groundwater-levels measured in 1995 and 2005. For the 1945 to 1955 period, only 7 percent of the targets used groundwaterlevels measured in 1945 and 1955.

To reduce the effect of unevenly distributed calibration targets across the study area, some targets were randomly removed from certain small areas of a decadal set if too many wells had the targeted change value measured in that small area. This reduced the tendency for areas with many target measurements to skew the calibration response of areas with fewer data points. Despite these efforts, the final decadal sets of measured groundwater-level changes were not distributed evenly across the study area, nor were there an equal number of calibration targets for all time periods. Generally, there were more measured changes of groundwater levels for recent decades than for early decades; the 1995 to 2005 period had 938 groundwater-level-change targets, whereas there were 273 targets for 1945-55, 230 targets for 1955-65, 350 targets for 1965-75, 652 targets for 1975-85, and 816 targets for 1985-95. The final set of groundwater-levelchange targets for all 6 decadal increments included 3,259 calibration targets (fig 12).

\section{Base-Flow Targets}

Streamflow measured at streamflow-gaging stations consists of runoff and base flow, which is the portion derived from groundwater discharge to streams. The phase-two ELM simulates only that part of streamflow derived from groundwater discharge to streams; therefore, base flows were used as calibration targets for the simulation. Annual base flow was estimated from streamflow data (Nebraska Department of Natural Resources, 2008; U.S. Geological Survey, 2008) recorded at streamflow-gaging stations in the study area using a baseflow separation method that combines a local minimums approach with a recession slope test (Wahl and Wahl, 2007) (table 2). Several stations within the study area were not used in the simulation because they were located in areas near the northern boundary where simulation results were less reliable and base-flow targets were not useful during the calibration process. Base-flow separation provided 1,435 annual baseflow targets at 38 streamflow-gaging stations (figs. 11 and 12). The number of targets per site was dependent upon the length of flow record at the streamflow-gaging station. Nine streamflow-gaging stations were on regulated streams downstream from a reservoir or canal diversions, where separation techniques generally are not reliable because the method interprets regulated releases as base flow (Wahl and Wahl, 2007); therefore, the average daily base-flow calculations during April and October (months when canals are generally inactive) each year were used to define the average base flow for the entire year. Also, these sites were assigned a lower importance relative to other base-flow targets for the automated calibration process by using a smaller weight (appendix 2).

One of the data-collection activities of phase two was a synoptic survey of low-flow streamflows, measured throughout the study area during autumn 2006 (Peterson and Strauch, 2007). These measurements provided additional base-flow targets for calibrating the simulation. Because the calibration period ended in 2005, base flow in 2005 was estimated from the 2006 measurements. This was accomplished by determining the percent difference between base flows in 2005 and 2006 at streamflow-gaging stations that had a calculated base-flow value for 2005 and a 2006 low-flow measurement. This percentage difference was then applied to the stations having only the 2006 low-flow measurements and located upstream from those streamflow-gaged sites. If a site did not have a downstream streamflow-gaging station with baseflow observations for 2005 and 2006, that site was not used for calibrating the simulation. Although this method allowed incorporation of most of the 2006 low-flow measurements, there is uncertainty associated with those calibration targets because data from a few streamflow-gaged sites were used to adjust base-flow estimates at a large number of sites. Base flow estimated from 2006 low-flow measurements provided 165 base-flow calibration targets for 2005 (fig. 12).

Base-flow targets generally were unavailable for 1939 , yet it was necessary to estimate calibration targets for the pre1940 period. A base-flow target was estimated for 20 locations using the annual base-flow targets for the period of streamflow record at those sites (fig. 11). Initially, all of the pre-1940 base-flow targets were calculated as the median of the annual base-flow targets at that site. However, some sites exhibited 


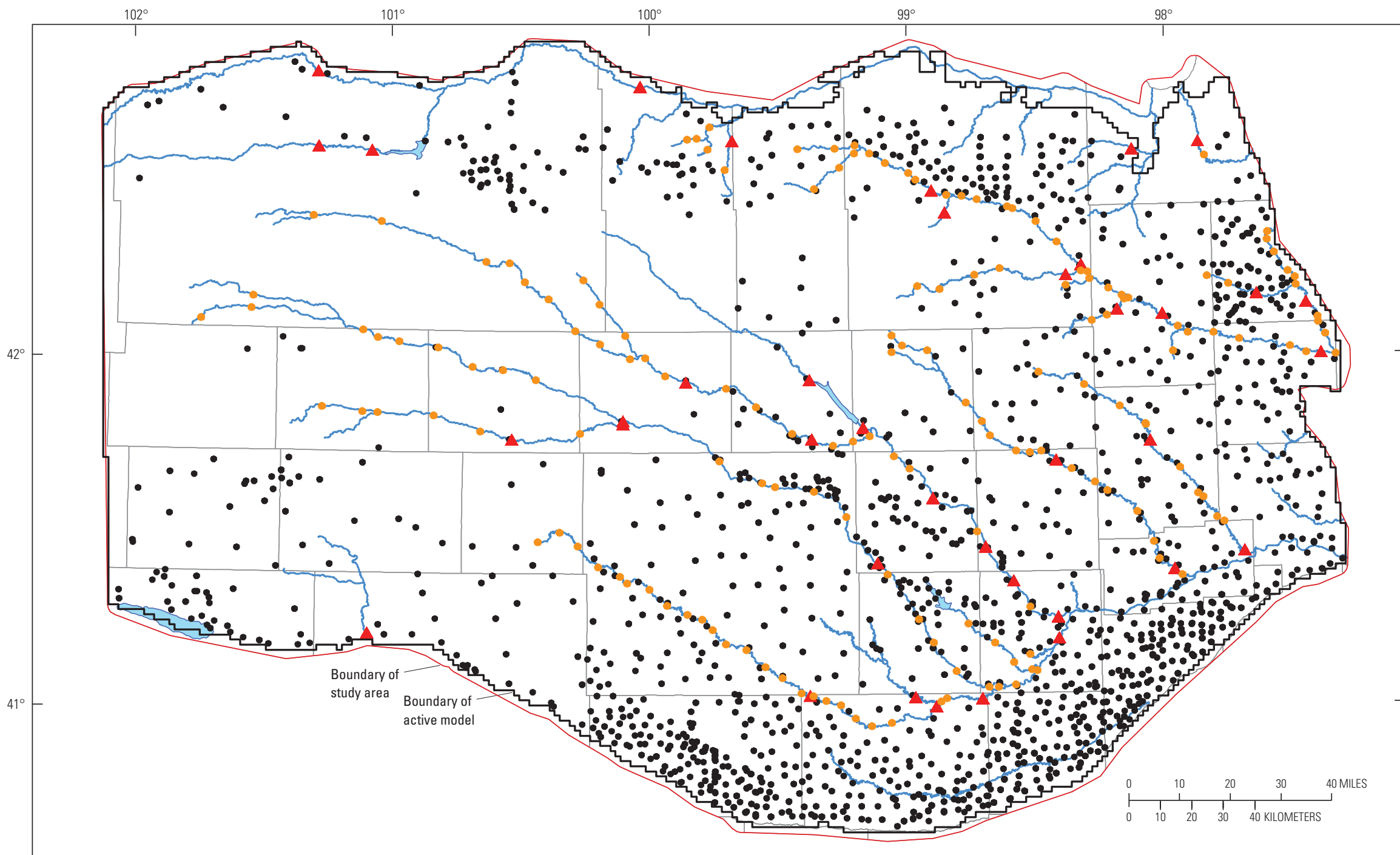

Base from U.S. Census Bureau, digital data, 2005, 1:100,000 Lambert Conformal Conic projection
Standard parallels $40^{\circ} \mathrm{N}$ and $43^{\circ} \mathrm{N}$, central meridian $100^{\circ} \mathrm{W}$ Horizontal coordinate information is referenced to the North

EXPLANATION

- Location of groundwater-level-change measurements used to calibrate the 1940 through 2005 simulation period

Streamflow-gaging station for which base flow was estimated,

and used to calibrate the 1940 through 2005 period

Site for which base flow was estimated for 2005 from a 2006 low-flow streamflow measurement, and used to calibrate the 1940 through 2005 simulation period

Figure 12. Distribution of groundwater-level-change measurements and base-flow observations used to calibrate the simulation for the 1940 through 2005 period, Elkhorn and Loup River Basins, Nebraska. 


\begin{tabular}{|c|c|c|c|c|c|c|c|c|}
\hline $\begin{array}{l}\text { Station } \\
\text { (fig. 12) }\end{array}$ & $\begin{array}{l}\text { Station } \\
\text { number }\end{array}$ & $\begin{array}{l}\text { Latitude, in } \\
\text { degrees, minutes, } \\
\text { seconds }\end{array}$ & $\begin{array}{l}\text { Longitude, in } \\
\text { degrees, minutes, } \\
\text { seconds }\end{array}$ & $\begin{array}{c}\text { Ratio of base flow } \\
\text { to total } \\
\text { streamflow }\end{array}$ & $\begin{array}{l}\text { Standard } \\
\text { deviation }\end{array}$ & $\begin{array}{l}\text { Beginning year } \\
\text { for base-flow } \\
\text { calculations }\end{array}$ & $\begin{array}{l}\text { Ending year } \\
\text { for base-flow } \\
\text { calculations }\end{array}$ & $\begin{array}{c}\text { Number of } \\
\text { years with } \\
\text { streamflow } \\
\text { record }\end{array}$ \\
\hline Bazile Creek at Center & 06466400 & 423659 & 975241 & 0.63 & 0.10 & 2003 & 2007 & 5 \\
\hline Beaver Creek at Loretto & 06793500 & 414548 & 980512 & .70 & .09 & 1945 & 2003 & 30 \\
\hline Beaver Creek at Genoa & 06794000 & 412629 & 974404 & .64 & .10 & 1941 & 2007 & 67 \\
\hline Birdwood Creek near Hershey ${ }^{1}$ & 06692000 & 411318 & 1010413 & .92 & .04 & 1932 & 2003 & 64 \\
\hline Calamus River near Burwell $^{1}$ & 06787500 & 414837 & 991059 & .87 & .05 & 1941 & 2003 & 61 \\
\hline Calamus River near Harrop & 06787000 & 415649 & 992310 & .91 & .03 & 1979 & 2003 & 23 \\
\hline Cedar River near Fullerton & 06792000 & 412340 & 980014 & .71 & .08 & 1941 & 2004 & 64 \\
\hline Cedar River near Spalding & 06791500 & 414241 & 982649 & .81 & .07 & 1945 & 2004 & 56 \\
\hline Clearwater Creek near Clearwater & 06798300 & 420823 & 981214 & .69 & .10 & 1962 & 1994 & 19 \\
\hline Dismal River at Dunning & 06776500 & 414921 & 1000601 & .92 & .03 & 1946 & 1995 & 50 \\
\hline Dismal River near Thedford & 06775900 & 414643 & 1003131 & .96 & .02 & 1967 & 2007 & 41 \\
\hline Elkhorn River at Ewing & 06797500 & 421606 & 982022 & .59 & .13 & 1948 & 2007 & 60 \\
\hline Elkhorn River at Neligh & 06798500 & 420730 & 980152 & .64 & .12 & 1931 & 2004 & 70 \\
\hline Elkhorn River at Norfolk & 06799000 & 420014 & 972534 & .63 & .10 & 1946 & 2007 & 62 \\
\hline Elkhorn River near Atkinson & 06796973 & 422910 & 985441 & .55 & .15 & 1983 & 2004 & 22 \\
\hline Holt Creek near Emmet & 06796978 & 422523 & 985140 & .47 & .12 & 1979 & 1989 & 11 \\
\hline Long Pine Creek near Long Pine & 06463080 & 423755 & 994047 & .95 & .03 & 1980 & 1990 & 11 \\
\hline Middle Loup River at Arcadia ${ }^{1}$ & 06779000 & 412519 & 990754 & .78 & .05 & 1938 & 1994 & 57 \\
\hline Middle Loup River at Dunning & 06775500 & 414951 & 1000558 & .95 & .02 & 1946 & 2007 & 62 \\
\hline Middle Loup River at Saint Paul ${ }^{1}$ & 06785000 & 411213 & 982646 & .63 & .07 & 1929 & 2007 & 79 \\
\hline Mud Creek near Sweetwater & 06783500 & 410217 & 985934 & .60 & .15 & 1947 & 2003 & 55 \\
\hline Niobrara River near Cody & 06459000 & 424940 & 1011702 & .79 & .04 & 1948 & 1956 & 9 \\
\hline Niobrara River near Norden & 06462000 & 424713 & 1000206 & .80 & .04 & 1954 & 1986 & 31 \\
\hline North Branch Verdigre Creek near Verdigre & 06465680 & 423550 & 980804 & .87 & .02 & 1980 & 1992 & 13 \\
\hline North Fork Elkhorn River near Pierce & 06799100 & 420855 & 972843 & .58 & .13 & 1961 & 2007 & 47 \\
\hline North Loup River at Brewster & 06785500 & 415630 & 995137 & .82 & .04 & 1946 & 1951 & 6 \\
\hline North Loup River near Cotesfield ${ }^{1}$ & 06790000 & 412211 & 983651 & .76 & .05 & 1951 & 1956 & 6 \\
\hline North Loup River at Ord ${ }^{1}$ & 06788500 & 413623 & 985511 & .79 & .04 & 1953 & 2003 & 49 \\
\hline North Loup River at Scotia ${ }^{1}$ & 06789000 & 412758 & 984316 & .71 & .06 & 1938 & 1969 & 32 \\
\hline North Loup River at Taylor ${ }^{1}$ & 06786000 & 414637 & 992245 & .78 & .05 & 1938 & 2007 & 70 \\
\hline North Loup River near Saint Paul ${ }^{1}$ & 06790500 & 411548 & 982656 & .73 & .06 & 1929 & 2007 & 79 \\
\hline Snake River at Doughboy & 06459175 & 423650 & 1011640 & .94 & .02 & 1982 & 2004 & 23 \\
\hline Snake River above Merritt Reservoir & 06459200 & 423613 & 1010416 & .92 & .02 & 1963 & 1981 & 19 \\
\hline South Fork Elkhorn River near Ewing & 06798000 & 421429 & 982354 & .66 & .14 & 1948 & 2004 & 45 \\
\hline South Loup River at Ravenna & 06782500 & 410043 & 985451 & .67 & .10 & 1941 & 1975 & 26 \\
\hline South Loup River at Saint Michael & 06784000 & 410157 & 984426 & .69 & .10 & 1944 & 2007 & 64 \\
\hline South Loup River near Cumro & 06782000 & 410241 & 992332 & .82 & .09 & 1947 & 1953 & 7 \\
\hline Willow Creek near Foster & 06799080 & 421038 & 974003 & .64 & .11 & 1976 & 2004 & 29 \\
\hline Mean & & & & .75 & 0.07 & & & 40.1 \\
\hline
\end{tabular}


base-flow trends that caused the median to be substantially different than early base-flow values. Therefore, pre-1940 base-flow targets for four sites were estimated on the basis of annual base-flow trends from early in the respective period of record. One site's base-flow target was set equal to the average of its minimum and maximum annual base-flow during the period of streamflow record.

\section{Calibration Results}

Simulated groundwater levels, groundwater-level changes, and base flows were compared with calibration targets to determine the accuracy and precision of the simulation in reproducing historical hydrologic conditions. Several types of quantitative measures commonly are employed to evaluate differences between simulated and measured values: the mean difference, the mean absolute difference, and the root-meansquared (RMS) difference (Anderson and Woessner, 1992). The mean difference is the mean of all differences between simulated and measured values. The mean absolute difference is the mean of the absolute value of the difference between simulated and measured values. The RMS difference is similar to the standard deviation, and is the square root of the meansquared differences between simulated and measured values.

\section{Pre-1940 Groundwater Levels}

Simulated 1939 groundwater level was within $30 \mathrm{ft}$ of the measured groundwater level for 409 of the 506 groundwaterlevel targets (81 percent) (fig. 13). Simulated 1939 groundwater level was within $60 \mathrm{ft}$ of the measured groundwater level at 477 calibration points (94 percent). Differences between simulated and measured groundwater level ranged from -332 to $255 \mathrm{ft}$. Many of the largest differences were near the northern boundary of the ELM area where steep hydraulic gradients exist that may be difficult to simulate accurately with 1-mi grid cells. Results indicate that no large areas of simulated groundwater levels were biased too high or too low, indicating that the simulation generally captured the regional trends, and that recharge and discharge components of the simulation were balanced.

The mean difference between the 1939 measured and simulated groundwater levels was $3.7 \mathrm{ft}$, the mean absolute difference was $19.9 \mathrm{ft}$, and the RMS difference was $35.1 \mathrm{ft}$. The mean difference was close to zero, indicating that simulated groundwater levels were not systematically biased, too high or too low. It generally is accepted that the RMS difference should be a small percentage of the total variation in simulated groundwater levels within the simulation area (Anderson and Woessner, 1992). The calibration criterion for this simulation was to attain an RMS difference of 5 percent or less of the total range of groundwater levels from highest to lowest across the system. The RMS difference for this simulation, at $35.1 \mathrm{ft}$, was 1.4 percent of the total range in simulated groundwater levels, and 1.3 percent of the total relief of the water table in 1979 (about 2,650 ft) (Conservation and Survey Division, 1996c).

Simulated groundwater-level-elevation contours for 1939 are shown alongside published interpolated groundwaterlevel-elevation contours for 1979 (Conservation and Survey Division, 1996c) in figure 14. This comparison indicates that simulated groundwater levels generally match the published contours; however, the simulated groundwater-level-elevation contours are more generalized and do not perfectly represent localized relief in some areas, particularly along the northern boundary of the study area. In some areas, the mismatch between the simulated and published groundwater-levelelevation contours can be at least partly explained because observations indicate that groundwater levels had changed between 1939 and 1979, particularly near canal delivery areas (fig. 9). In addition, the published contours represent a handdrawn interpretation of groundwater-level data, which also has associated subjectivity and uncertainty.

\section{5 through 2005 Groundwater-Level Changes}

A statistical summary of the differences remaining between the measured and simulated groundwater-level changes after calibration is listed for each 10-year time period in table 3. The mean difference, mean absolute difference, and RMS difference between measured and simulated groundwater-level changes for all of the time periods were averaged and weighted based on the number of calibration points in each time period. The weighted-average mean difference was -1.20 $\mathrm{ft}$ per decade, the weighted-average mean absolute difference was $3.56 \mathrm{ft}$ per decade, and the weighted-average RMS difference was $5.12 \mathrm{ft}$ per decade. These statistical measures of the accuracy of simulation results are slightly worse than those determined for the phase-one simulation; however, this outcome was expected because the calibration procedure for the phase-one simulation placed a greater importance on groundwater-level change targets relative to base-flow targets. For the phase-two simulation, time-variant base-flow targets were introduced, and the accuracy of the calibrated simulation was evaluated with respect to groundwater-level change and base-flow target values.

A majority of simulated groundwater-level changes per decade were less than $5 \mathrm{ft}$ different than measured groundwater-level changes. A difference of $5 \mathrm{ft}$ or less was deemed a satisfactory reproduction of measured values given the potential variability of decadal groundwater-level change and the uncertainty associated with the target selection process. For earlier time periods, a greater percentage of sites had a difference of less than $5 \mathrm{ft}$ between measured and simulated groundwater-level changes. One explanation for this is that a larger percentage of calibration points were located closer to streams in earlier time periods, and groundwater levels in those areas of groundwater discharge were less likely to change in the actual aquifer system or the simulated system.

Measured and simulated groundwater-level changes for each time period are shown in figures 15-20. In most areas and 


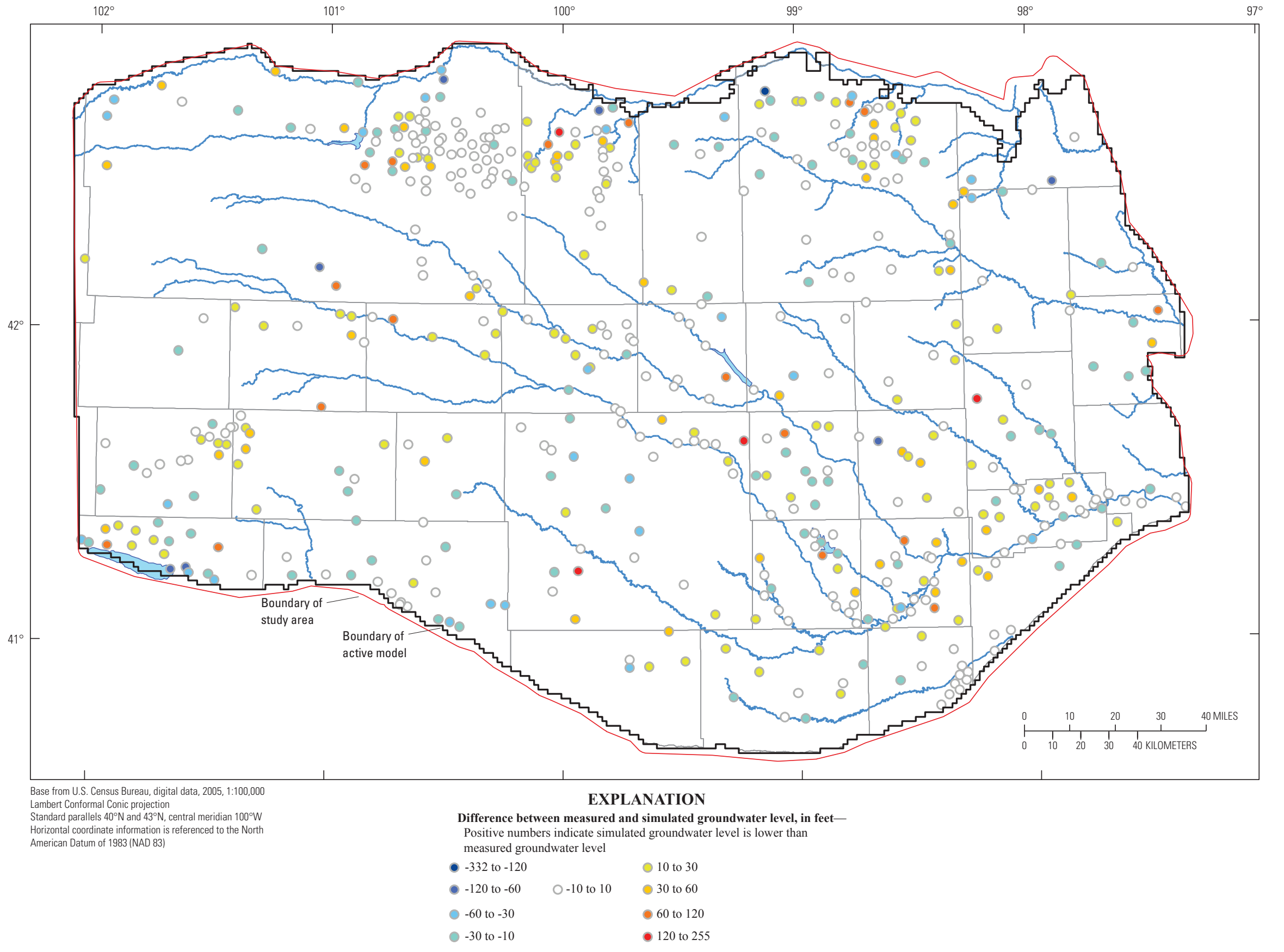

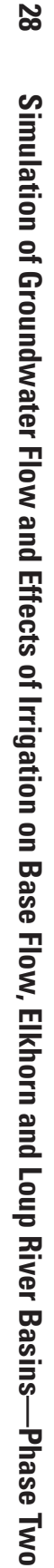

Figure 13. Differences between measured and simulated groundwater levels, 1939, Elkhorn and Loup River Basins, Nebraska. 


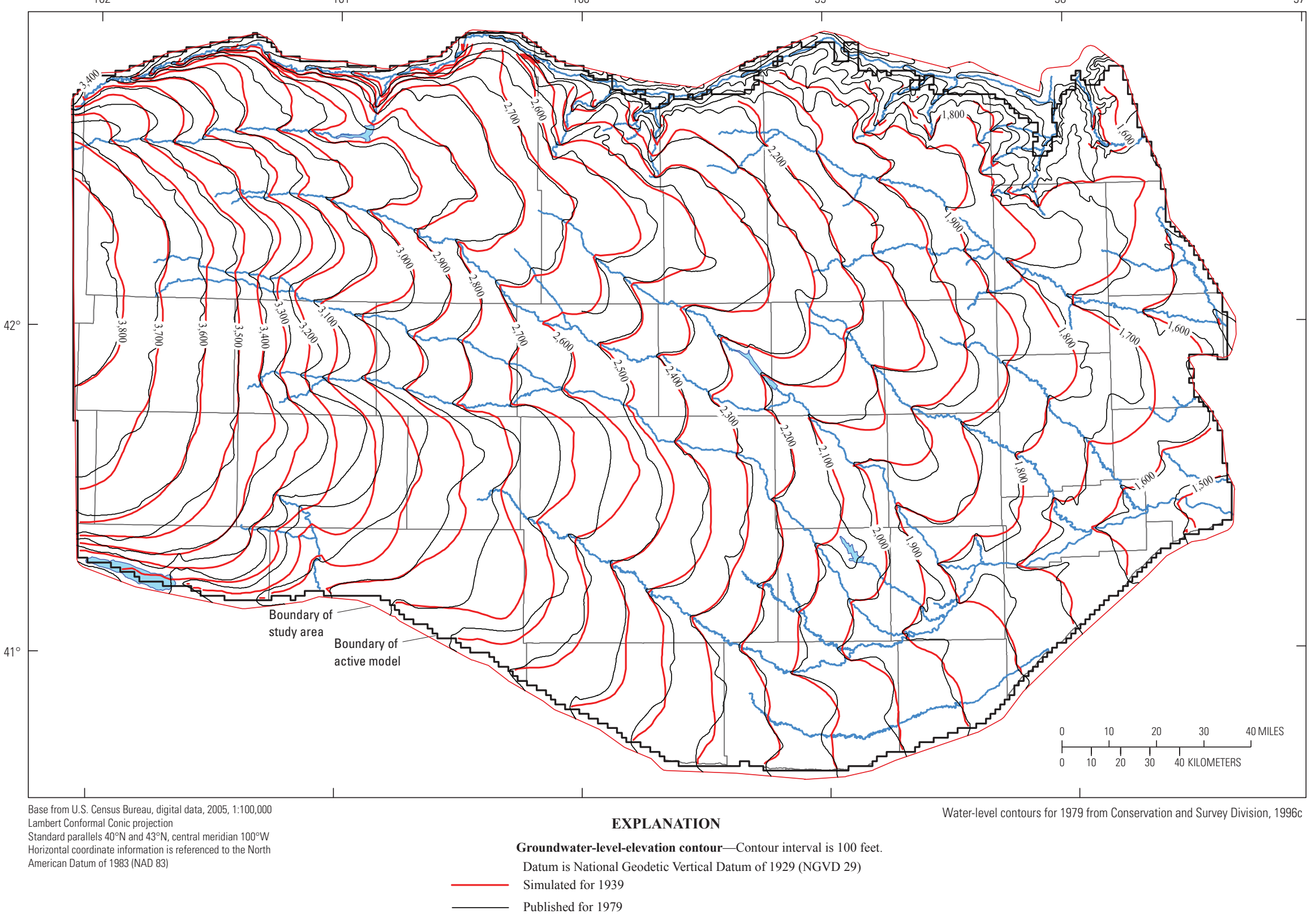

Figure 14. Simulated 1939 and previously published 1979 groundwater-level-elevation contours, Elkhorn and Loup River Basins, Nebraska. 
Table 3. Statistical summary of calibration to decadal groundwater-level-change targets, 1945-2005.

\begin{tabular}{cccccccc}
\hline Time period & $\begin{array}{c}\text { Number } \\
\text { of sites }\end{array}$ & $\begin{array}{c}\text { Minimum } \\
\text { difference, } \\
\text { in feet }\end{array}$ & $\begin{array}{c}\text { Maximum } \\
\text { difference, } \\
\text { in feet }\end{array}$ & $\begin{array}{c}\text { Mean } \\
\text { difference, } \\
\text { in feet }\end{array}$ & $\begin{array}{c}\text { Mean absolute } \\
\text { difference, } \\
\text { in feet }\end{array}$ & $\begin{array}{c}\text { Root mean } \\
\text { squared } \\
\text { difference, } \\
\text { in feet }\end{array}$ & $\begin{array}{c}\text { Percent of } \\
\text { sites with a } \\
\text { difference of } \\
\text { 5 feet or less }\end{array}$ \\
\hline $1945-1955$ & 273 & -24.8 & 12.1 & 0.73 & 2.13 & 3.23 & 92 \\
$1955-1965$ & 230 & -48.9 & 8.4 & -1.67 & 2.58 & 4.75 & 91 \\
$1965-1975$ & 350 & -37.1 & 13.1 & -2.21 & 4.05 & 6.67 & 74 \\
$1975-1985$ & 652 & -22.0 & 21.2 & -2.38 & 4.34 & 5.73 & 68 \\
$1985-1995$ & 816 & -55.1 & 18.9 & -1.79 & 3.26 & 4.75 & 78 \\
$1995-2005$ & 938 & -35.6 & 34.7 & .06 & 3.74 & 5.09 & 75 \\
\hline
\end{tabular}

time periods, groundwater-level changes were similar for both simulated and observed values; however, several areas had disagreement between measured and simulated groundwater-level change. In the Cozad and Gothenburg Canal areas (fig. 9), the model simulated groundwater-level rises from 1945 to 1955 that are not supported by measured groundwater-level changes. This pattern also was observed in the phase-one simulation results. Simulated groundwater-level rises from decades after 1975 (decades corresponding to the most development) generally were smaller than measured groundwater-level rises near the irrigation districts located in the Loup River system, indicating that either simulated canal-seepage recharge was underestimated or net irrigation pumpage was overestimated.

Simulated groundwater-level declines were larger than measured groundwater-level declines in several parts of the study area having large amounts of irrigated cropland. One area where simulated groundwater-level declines were excessive is north of the Elkhorn River in Holt County, where simulated declines were particularly large for 1965 to 1975 , 1975 to 1985 , and 1995 to 2005. Simulated groundwater-level declines also were larger than measured declines in parts of Hall and Buffalo Counties, particularly for the 1995 to 2005 time period. These areas coincide with more intense irrigation than other parts of the study area and excessive groundwaterlevel declines may have resulted from overestimation of net irrigation pumpage.

Simulated groundwater levels also were compared with time-series hydrographs of measured groundwater levels for selected wells (fig. 21). Site locations for these comparisons were chosen primarily on the basis of availability of long-term groundwater-level measurements, spatial distribution, distance from surface-water features, and well-screen depth relative to the water table. Sites were chosen so that at least one observed hydrograph is shown for an area of groundwater-level rise, an area of groundwater-level decline, and an area with little or no rise or decline. At 7 of the 10 sites, simulated groundwaterlevel altitudes were similar to measured values by 2005 ; however, at one site (fig. 21J), the initial simulated groundwater-level was about $30 \mathrm{ft}$ too low. The hydrographs at two sites (figs. $21 \mathrm{D}$ and $21 \mathrm{H}$ ) show considerable declines during the simulation that were not observed in measured groundwater levels. These two sites are located in the two areas previously mentioned where simulated groundwater-level declines were much larger than measured changes. The hydrograph at a third site (fig. $21 G$ ) shows that simulated groundwater levels were lower than measured groundwater levels, but groundwaterlevel trends acceptably. This indicates that although the initial simulated groundwater level was too low, simulated recharge and discharge components were generally realistic during the 1940 through 2005 period.

\section{Base Flows}

A more thorough comparison with base-flow trends was undertaken for the phase-two simulation calibration than had been attempted for the phase-one simulation. The mean difference between estimated and simulated annual base flows, averaged over 1,600 calibration targets (a combination of 1,435 annual base-flow targets at 38 streamflow-gaging stations and 165 low-flow measurements) from the 1940 through 2005 period, was small $\left(-11 \mathrm{ft}^{3} / \mathrm{s}\right)$. The mean absolute difference in annual base flow was $53 \mathrm{ft}^{3} / \mathrm{s}$, and the RMS difference was $106 \mathrm{ft}^{3} / \mathrm{s}$ (table 4). An RMS difference of $106 \mathrm{ft}^{3} / \mathrm{s}$ was considered a good agreement with target base flows because it was less than the average range of annual base flow at each of the 38 streamflow-gaging station's respective period of record (about $160 \mathrm{ft}^{3} / \mathrm{s}$ ). Many of the differences between estimated and simulated base flows were from base-flow targets that fluctuated substantially from year to year (primarily at sites outside the Sand Hills). Differences expressed as a percentage of mean annual estimated base flow were larger for streams with less than $10 \mathrm{ft}^{3} / \mathrm{s}$ of annual base flow (table 4). This result was expected because regional simulations such as the ELM do not have sufficient spatial and temporal resolution to characterize with precision the local hydrogeologic processes that can affect the amount of groundwater discharging to small streams. The lack of precision also could correspond to the general decrease in the number of targets having less than $10 \mathrm{ft}^{3} / \mathrm{s}$ annual base flow. When differences between estimated and simulated annual base flows were summarized by site for the 38 streamflow-gaging stations, the mean difference 


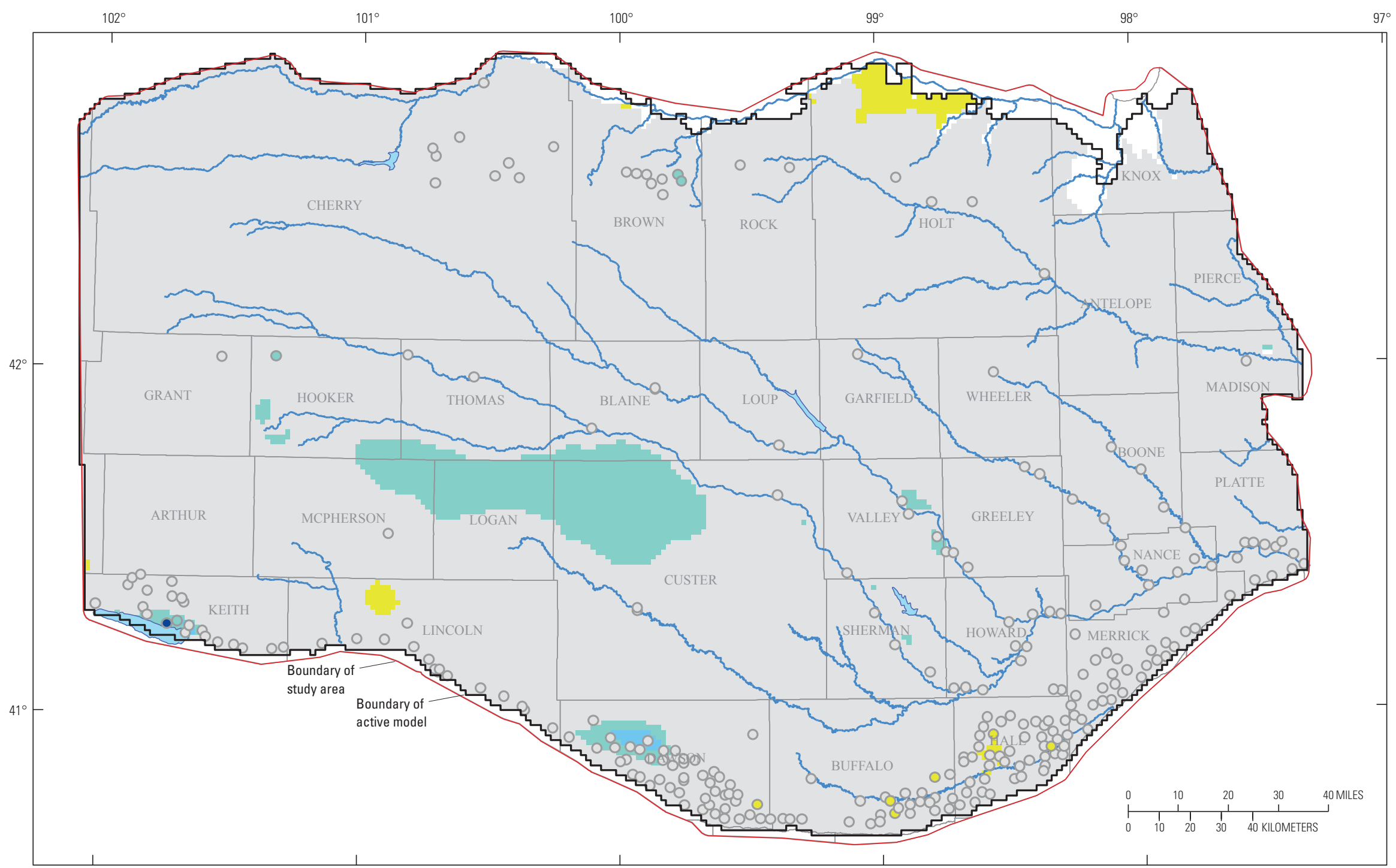

Base from U.S. Census Bureau, digital data, 2005, 1:100,000 EXPLANATION

Lambert Conformal Conic projection Horizontal coordinate information is referenceded to the North

American Datum of 1983 (NAD 83)

Groundwater-level change, 1945 to 1955 , in feet- - hitte area represents grid cell that becomes inactive during the iterative approximations of groundwater-flow equations. Measured groundwater levels from U.S. Geological Survey, 2005

Groundwater-level rises

Small rise or decline

Groundwater-level declines

Measured Simulated $\quad$ Measured Simulated Measured Simulated

\begin{tabular}{l|l}
$\circ$ & 5 to 10 \\
\hline & 10 to 15
\end{tabular}

O $\quad-5$ to 5

- 5 to 10

Greater than 25 


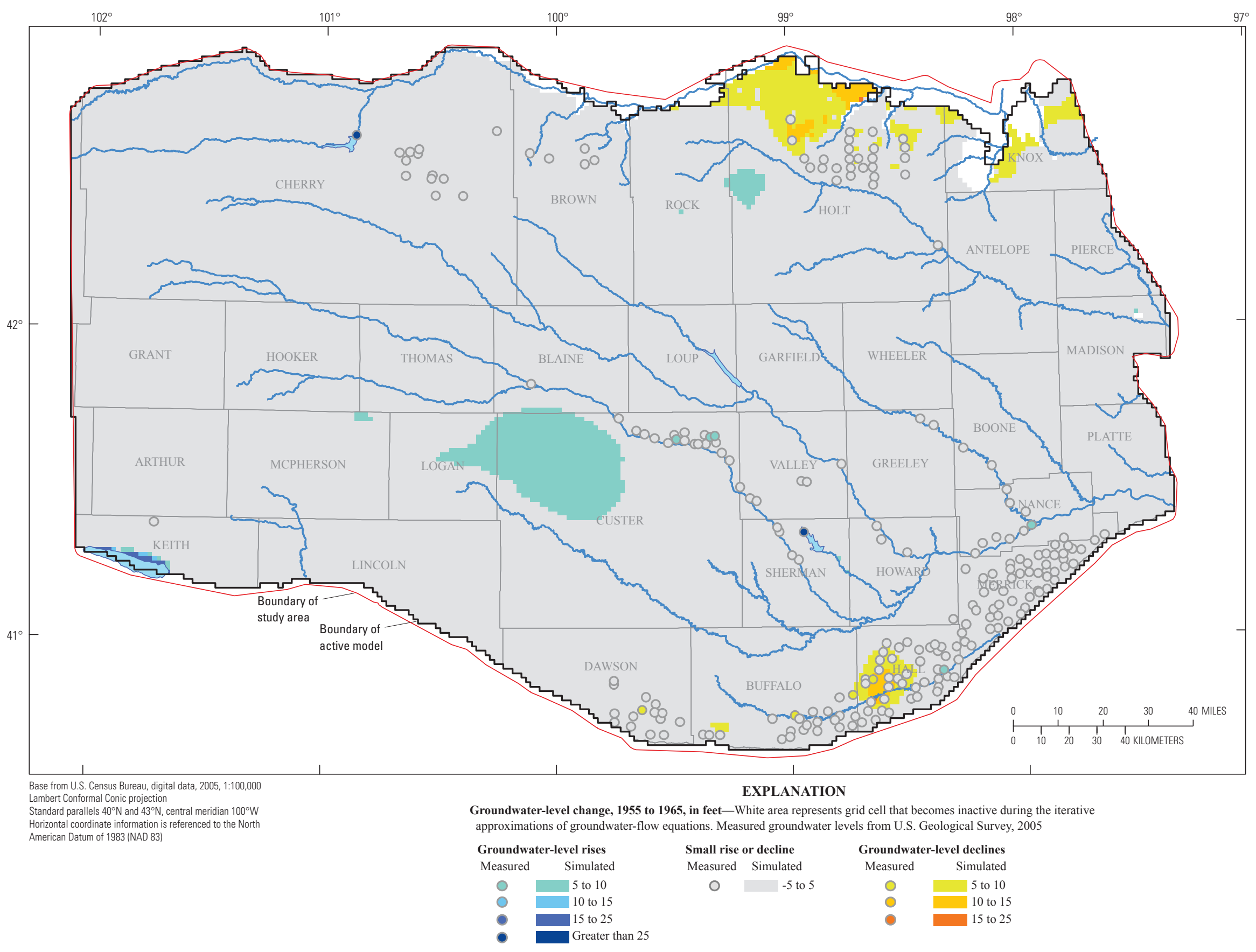

Figure 16. Measured and simulated groundwater-level change, 1955 to 1965, Elkhorn and Loup River Basins, Nebraska. 


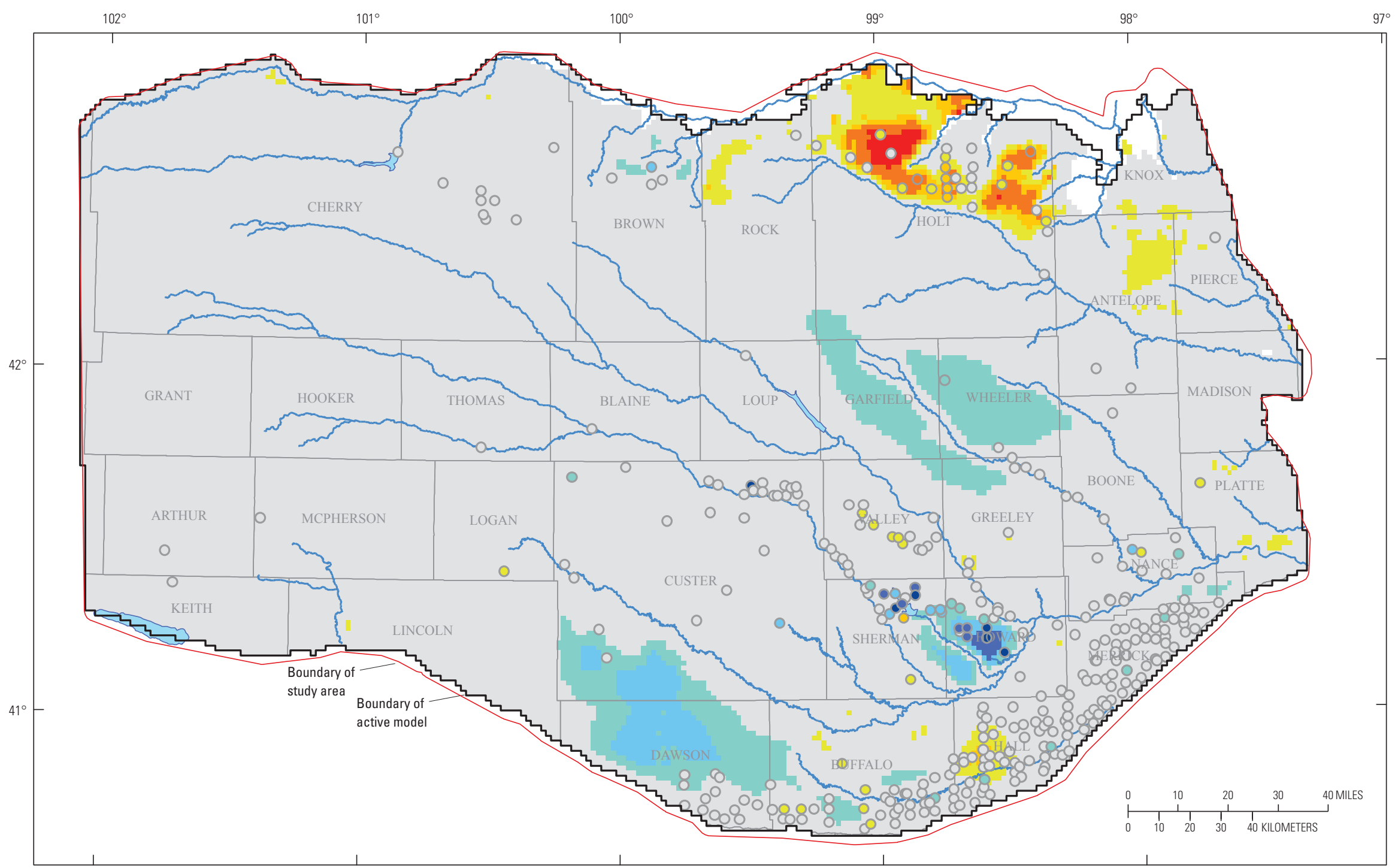

Base from U.S. Census Bureau, digital data, 2005, 1:100,000 Lambert Conformal Conic projection

Standard parallels $40^{\circ} \mathrm{N}$ and $43^{\circ} \mathrm{N}$, central meridian $100^{\circ} \mathrm{W}$ EXPLANATION

Horizontal toord inate intormation is referenced to the Nort

Groundwater-level change, 1965 to 1975 , in feet-White area represents grid cell that becomes inactive during the iterative

approximations of groundwater-flow equations. Measured groundwater levels from U.S. Geological Survey, 2005

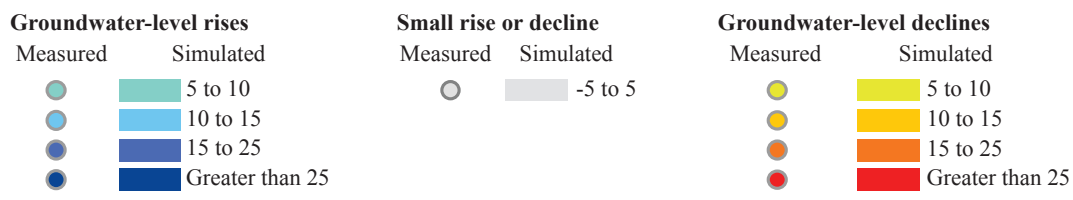

Figure 17. Measured and simulated groundwater-level change, 1965 to 1975, Elkhorn and Loup River Basins, Nebraska 


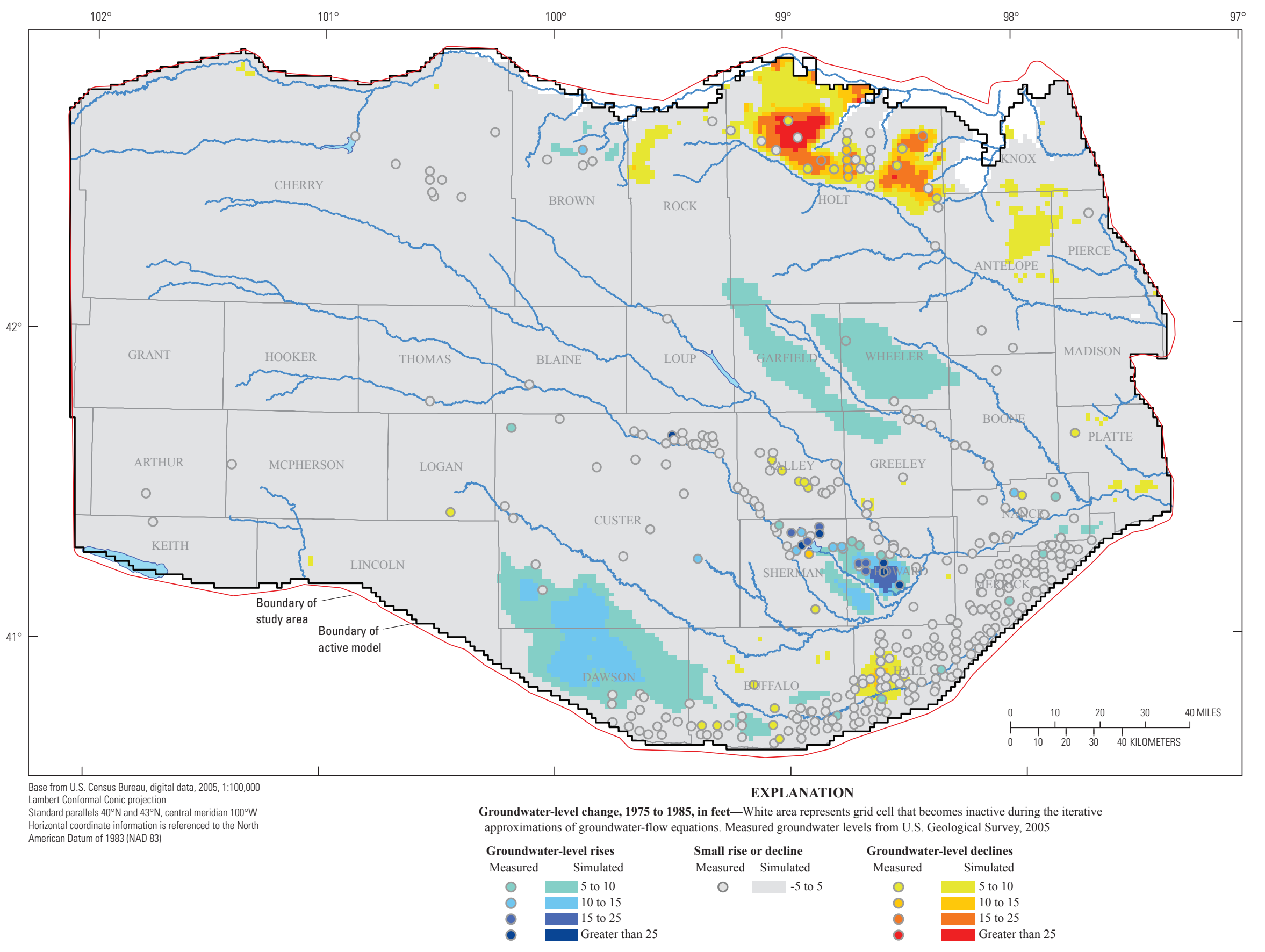

Figure 18. Measured and simulated groundwater-level change, 1975 to 1985, Elkhorn and Loup River Basins, Nebraska. 

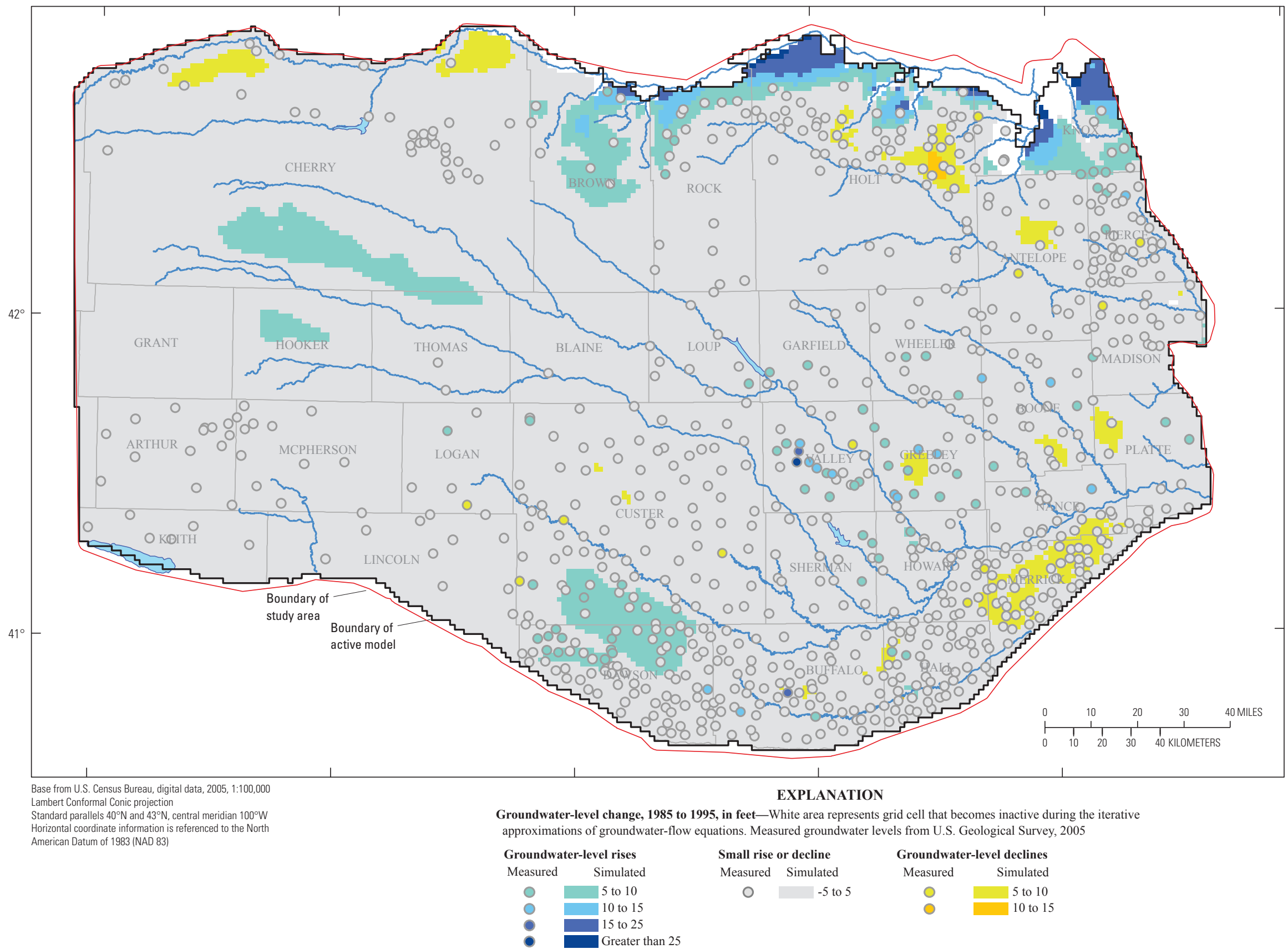


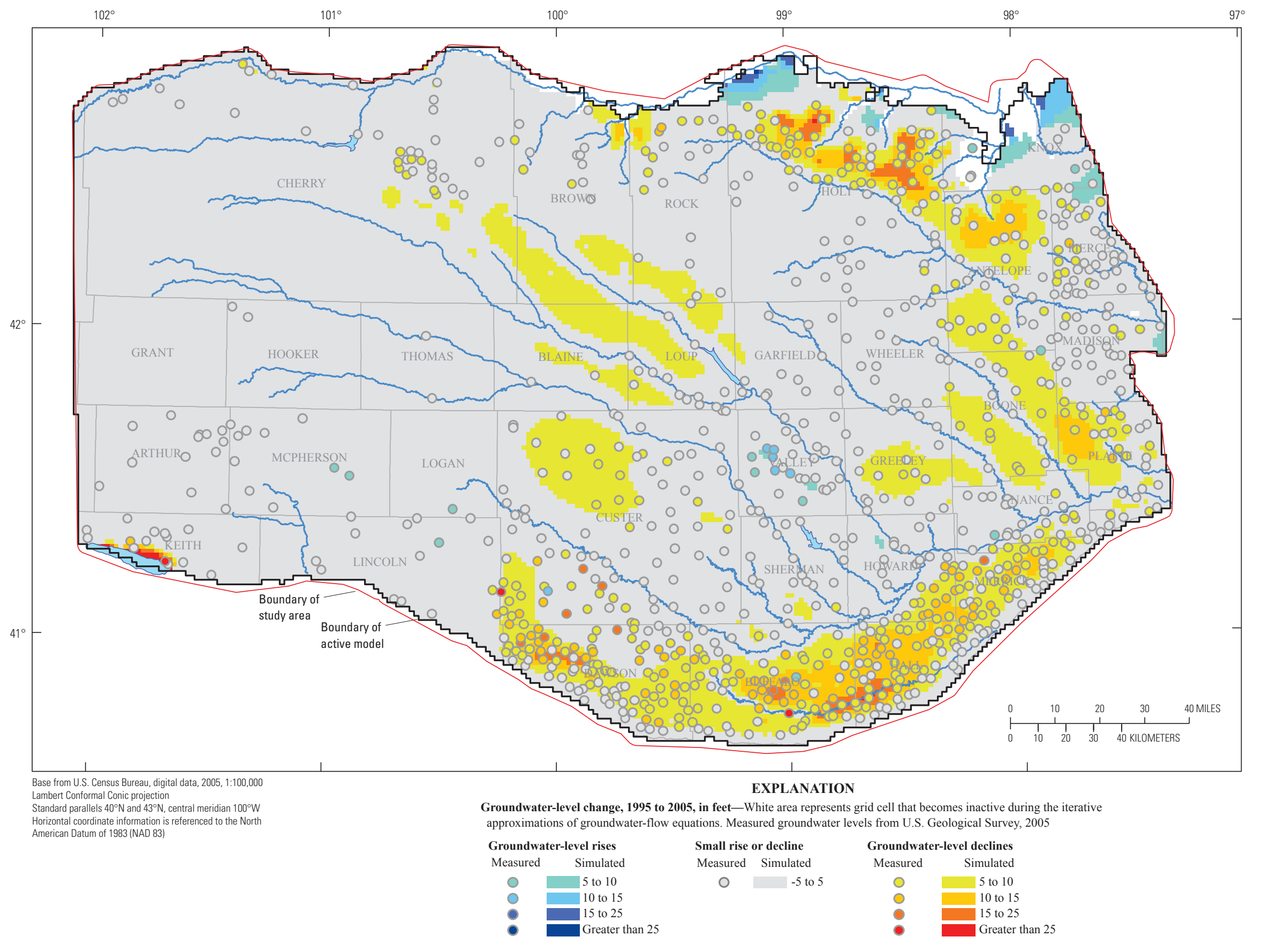

Figure 20. Measured and simulated groundwater-level change, 1995 to 2005, Elkhorn and Loup River Basins, Nebraska. 


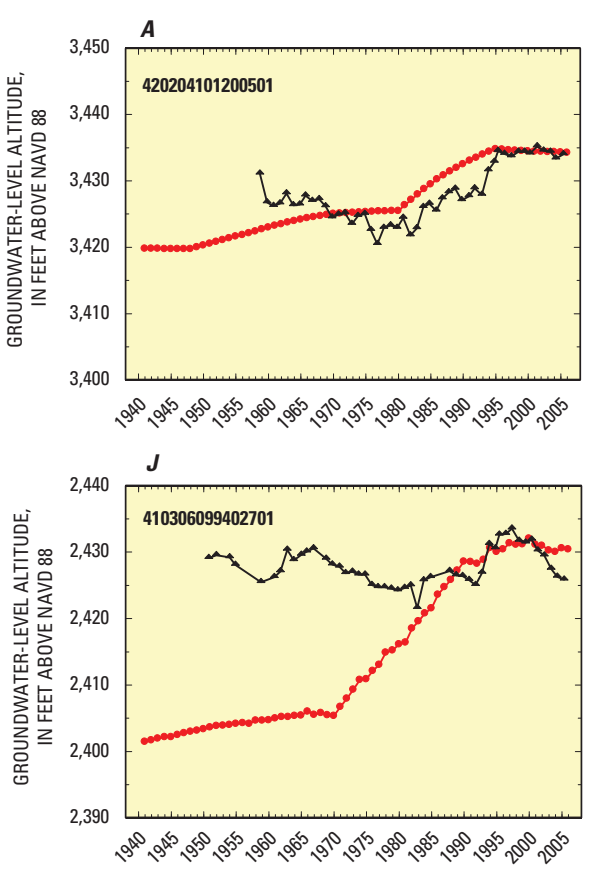

EXPLANATION

\section{Number of irrigated acres per square mile in} 205 (Center for Advanced Land Management 1to 100 Tohnologies, 2007)

100 to 200

200 to 300

300 to 400

400 to 500

500 to 600

600 to 640

- Measured groundwater-level altitude

$\rightarrow$ Simulated groundwater-level altitude
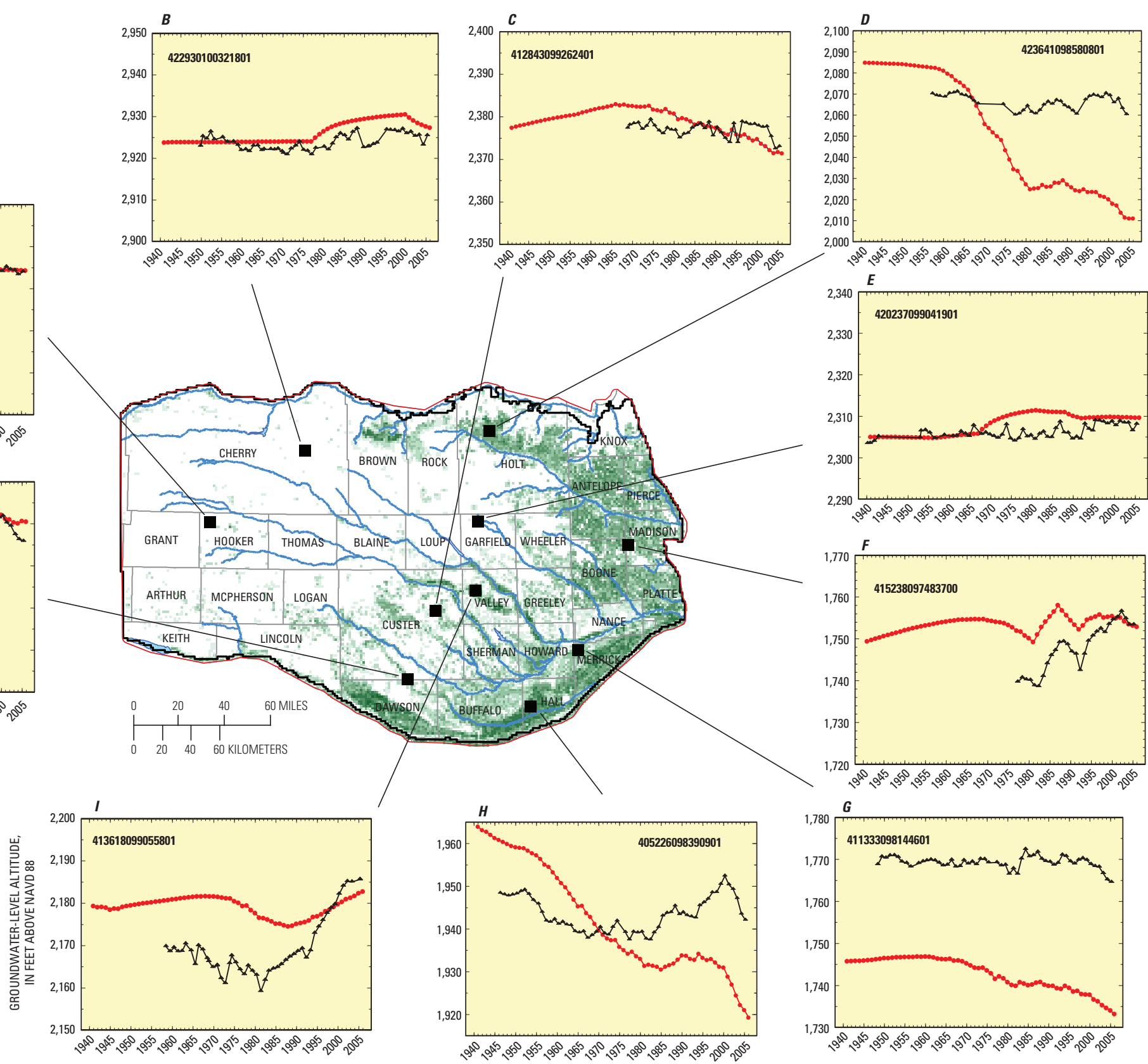

Figure 21. Measured and simulated groundwater levels, 1940 through 2005, and number of irrigated acres per square mile, 2005, Elkhorn and Loup River Basins, Nebraska. 
Table 4. Difference between estimated and simulated annual base flow by stream size, 1940-2005, Elkhorn and Loup River Basins, Nebraska.

$\left[\mathrm{ft}^{3} / \mathrm{s}\right.$, cubic feet per second]

\begin{tabular}{|c|c|c|c|c|c|c|c|}
\hline $\begin{array}{c}\text { Estimated } \\
\text { base flow, } \\
\text { in } \mathrm{ft}^{3} / \mathrm{s}\end{array}$ & Count & $\begin{array}{c}\text { Mean } \\
\text { estimated } \\
\text { base flow, } \\
\text { in } \mathrm{ft}^{3} / \mathrm{s}\end{array}$ & $\begin{array}{c}\text { Mean } \\
\text { simulated, } \\
\text { in } \mathrm{ft}^{3} / \mathrm{s}\end{array}$ & $\begin{array}{c}\text { Percent } \\
\text { difference } \\
\text { from mean } \\
\text { estimated }\end{array}$ & $\begin{array}{c}\text { Mean } \\
\text { difference, } \\
\text { in } \mathrm{ft}^{3} / \mathrm{s}\end{array}$ & $\begin{array}{l}\text { Mean absolute } \\
\text { difference, } \\
\text { in } \mathrm{ft}^{3} / \mathrm{s}\end{array}$ & $\begin{array}{c}\text { Root-mean- } \\
\text { squared } \\
\text { difference, } \\
\text { in } \mathrm{ft}^{3} / \mathrm{s}\end{array}$ \\
\hline Less than 10 & 48 & 4 & 6 & 50 & -1 & 5 & 7 \\
\hline 10 to 20 & 72 & 16 & 15 & -6 & 1 & 6 & 7 \\
\hline 20 to 50 & 158 & 33 & 35 & 6 & -2 & 15 & 23 \\
\hline 50 to 100 & 189 & 72 & 72 & -0 & 0 & 25 & 30 \\
\hline More than 100 & 1,133 & 406 & 422 & 4 & -16 & 69 & 124 \\
\hline All & 1,600 & 300 & 312 & 4 & -11 & 53 & 106 \\
\hline
\end{tabular}

was $-8 \mathrm{ft}^{3} / \mathrm{s}$, the mean absolute difference was $53 \mathrm{ft}^{3} / \mathrm{s}$, and the RMS difference was $97 \mathrm{ft}^{3} / \mathrm{s}$ (table 5).

For the 20 base-flow targets used for the pre-1940 period, the mean difference between estimated and simulated base flows was $1 \mathrm{ft}^{3} / \mathrm{s}$, the mean absolute difference was $34 \mathrm{ft}^{3} / \mathrm{s}$, and the RMS difference was $48 \mathrm{ft}^{3} / \mathrm{s}$.

Estimated and simulated annual base-flow values for selected streamflow-gaging stations are shown in figure 22 . Base-flow trends generally were reproduced by the simulation for most sites when compared with LOWESS (LOcally WEighted Scatterplot Smoothing) (Helsel and Hirsch, 1992) smoothed estimated base-flow values. In particular, streams that were the most dominated by base-flow were those where annual base flow was simulated most successfully. Exceptions to this were noted for several sites. Simulated base flow in Beaver Creek at Genoa (06794000) (fig. 22E) began to decline in the 1970s while estimated base flow increased until about 1995. Estimated and simulated base flows declined at about the same rate from 1995 to 2005 . As a result, simulated base flow of Beaver Creek was too low at the end of the calibration period. Similar patterns were observed for Cedar River near Fullerton (06792000) (fig. 22F) and Elkhorn River at Norfolk (06799000) (fig. 22D). Streamflow data for all three stations indicated a base-flow response to the Pacific decadal oscillation (PDO), which changed phase following 1977 (Mantua and Hare, 2002), whereas the simulated base flows did not respond to that shift and never recovered thereafter. In the Middle Loup River at Saint Paul (06785000) (fig. 22H), the simulated base-flow pattern is similar to estimated base-flow targets, but the base-flow rate is too large. Simulated base flows at upstream sites are similar in magnitude to estimated base flows, indicating that lower basin conditions (outside the Sand Hills) were not simulated correctly. It is possible that well pumpage was underestimated for Custer County (fig. 7), and additional simulated groundwater withdrawals would have resulted in smaller simulated base flow in parts of the Middle Loup River. The groundwater system in this area also is likely affected by surface-water irrigation districts and canal-seepage recharge may have been overestimated. Finally, base-flow target values in this area could be less reliable because of the effect from upstream irrigation districts (Wahl and Wahl, 2007). For this reason, sites downstream from irrigation districts were assigned base-flow values using data from only April and October (months when irrigation districts were not diverting water) and smaller calibration weights to lessen their effect on simulation results (appendix 2).

Measurements of low-flow streamflows collected in 2006 provided 165 base-flow targets for 2005 , or about 10 percent of the total number of base-flow calibration targets. Simulated base flow for 2005 was smaller than estimated base flow in the eastern part of the study area-in Cedar River, Beaver Creek, and the lower reaches of the Elkhorn River (fig. 23). Along the lower reaches of the Middle Loup River, simulated base flow was larger than the 2005 base-flow target values by more than $200 \mathrm{ft}^{3} / \mathrm{s}$. Some of the differences between estimated and simulated base-flow values probably were related to the large uncertainty associated with these targets. Base-flow targets for 2005 for sites located within the Sand Hills generally were similar to simulated base flows for 2005 .

\section{Simulated Groundwater Budget}

For the period representing steady-state conditions (pre-1895), the simulated aquifer received 95 percent of its water as recharge from precipitation, 2 percent as seepage from streams, and 2 percent as lateral flow from fixed waterlevel boundaries (table 6). Water exited the simulated aquifer as discharge to streams (62 percent), evapotranspiration (31 percent), and lateral flow to fixed water-level boundaries (7 percent).

Between 1895 and 1940, the construction of canals altered the water budget. In 1939, the simulation results indicate that 94 percent of water entering the aquifer was recharge from precipitation (table 6). Other sources of water were simulated streambed seepage ( 2 percent), canal-seepage recharge ( 2 percent), and fixed water-level boundaries ( 2 percent). Groundwater discharge to stream base flow accounted for 61 percent of the water leaving the simulated aquifer (outflow). Groundwater 
Table 5. Difference between estimated and simulated annual base flow by streamflow-gaging station, 1940-2005, Elkhorn and Loup River Basins, Nebraska.

[Values are in cubic feet per second]

\begin{tabular}{|c|c|c|c|c|c|}
\hline Station name & $\begin{array}{l}\text { Station } \\
\text { number }\end{array}$ & $\begin{array}{c}\text { Number of } \\
\text { calibration } \\
\text { targets }\end{array}$ & $\begin{array}{c}\text { Mean } \\
\text { difference }^{1}\end{array}$ & $\begin{array}{l}\text { Mean absolute } \\
\text { difference }\end{array}$ & $\begin{array}{l}\text { Root-mean- } \\
\text { squared } \\
\text { difference }\end{array}$ \\
\hline Bazile Creek at Center & 06466400 & 3 & 12 & 12 & 12 \\
\hline Beaver Creek at Genoa & 06794000 & 64 & 2 & 21 & 26 \\
\hline Beaver Creek at Loretto & 06793500 & 30 & 17 & 17 & 20 \\
\hline Birdwood Creek near Hershey & 06692000 & 60 & 0 & 10 & 13 \\
\hline Calamus River near Burwell & 06787500 & 46 & 2 & 21 & 26 \\
\hline Calamus River near Harrop & 06787000 & 22 & 18 & 25 & 32 \\
\hline Cedar River near Fullerton & 06792000 & 64 & 0 & 32 & 38 \\
\hline Cedar River near Spalding & 06791500 & 55 & -7 & 20 & 24 \\
\hline Clearwater Creek near Clearwater & 06798300 & 18 & 10 & 12 & 15 \\
\hline Dismal River at Dunning & 06776500 & 49 & 1 & 8 & 9 \\
\hline Dismal River near Thedford & 06775900 & 39 & -1 & 4 & 5 \\
\hline Elkhorn River at Ewing & 06797500 & 58 & -2 & 57 & 70 \\
\hline Elkhorn River at Neligh & 06798500 & 60 & -32 & 93 & 112 \\
\hline Elkhorn River at Norfolk & 06799000 & 60 & 5 & 109 & 135 \\
\hline Elkhorn River near Atkinson & 06796973 & 22 & 19 & 25 & 33 \\
\hline Holt Creek near Emmet & 06796978 & 11 & 12 & 12 & 15 \\
\hline Long Pine Creek near Long Pine & 06463080 & 12 & 31 & 31 & 31 \\
\hline Middle Loup River at Arcadia & 06779000 & 55 & -53 & 120 & 155 \\
\hline Middle Loup River at Dunning & 06775500 & 60 & 3 & 14 & 18 \\
\hline Middle Loup River at Saint Paul & 06785000 & 66 & -227 & 249 & 302 \\
\hline Mud Creek near Sweetwater & 06783500 & 51 & 3 & 6 & 8 \\
\hline Niobrara River near Cody & 06459000 & 8 & 124 & 124 & 125 \\
\hline Niobrara River near Norden & 06462000 & 30 & 185 & 185 & 199 \\
\hline North Branch Verdigre Creek near Verdigre & 06465680 & 13 & 12 & 12 & 13 \\
\hline North Fork Elkhorn River near Pierce & 06799100 & 45 & 18 & 21 & 31 \\
\hline North Loup River at Brewster & 06785500 & 6 & -19 & 27 & 33 \\
\hline North Loup River at Ord & 06788500 & 54 & 8 & 80 & 106 \\
\hline North Loup River at Scotia & 06789000 & 31 & -23 & 73 & 94 \\
\hline North Loup River at Taylor & 06786000 & 66 & 16 & 41 & 54 \\
\hline North Loup River near Cotesfield & 06790000 & 7 & -9 & 57 & 67 \\
\hline North Loup River near Saint Paul & 06790500 & 66 & -31 & 102 & 126 \\
\hline Snake River above Merritt Reservoir & 06459200 & 18 & -3 & 5 & 6 \\
\hline Snake River at Doughboy & 06459175 & 22 & 10 & 11 & 14 \\
\hline South Fork Elkhorn River near Ewing & 06798000 & 43 & -2 & 14 & 16 \\
\hline South Loup River at Ravenna & 06782500 & 25 & -10 & 19 & 23 \\
\hline South Loup River at Saint Michael & 06784000 & 61 & 7 & 21 & 29 \\
\hline South Loup River near Cumro & 06782000 & 6 & 19 & 19 & 20 \\
\hline Willow Creek near Foster & 06799080 & 29 & 5 & 5 & 6 \\
\hline
\end{tabular}

${ }^{1}$ Negative values indicate that simulated base flow was larger than estimated base flow. 

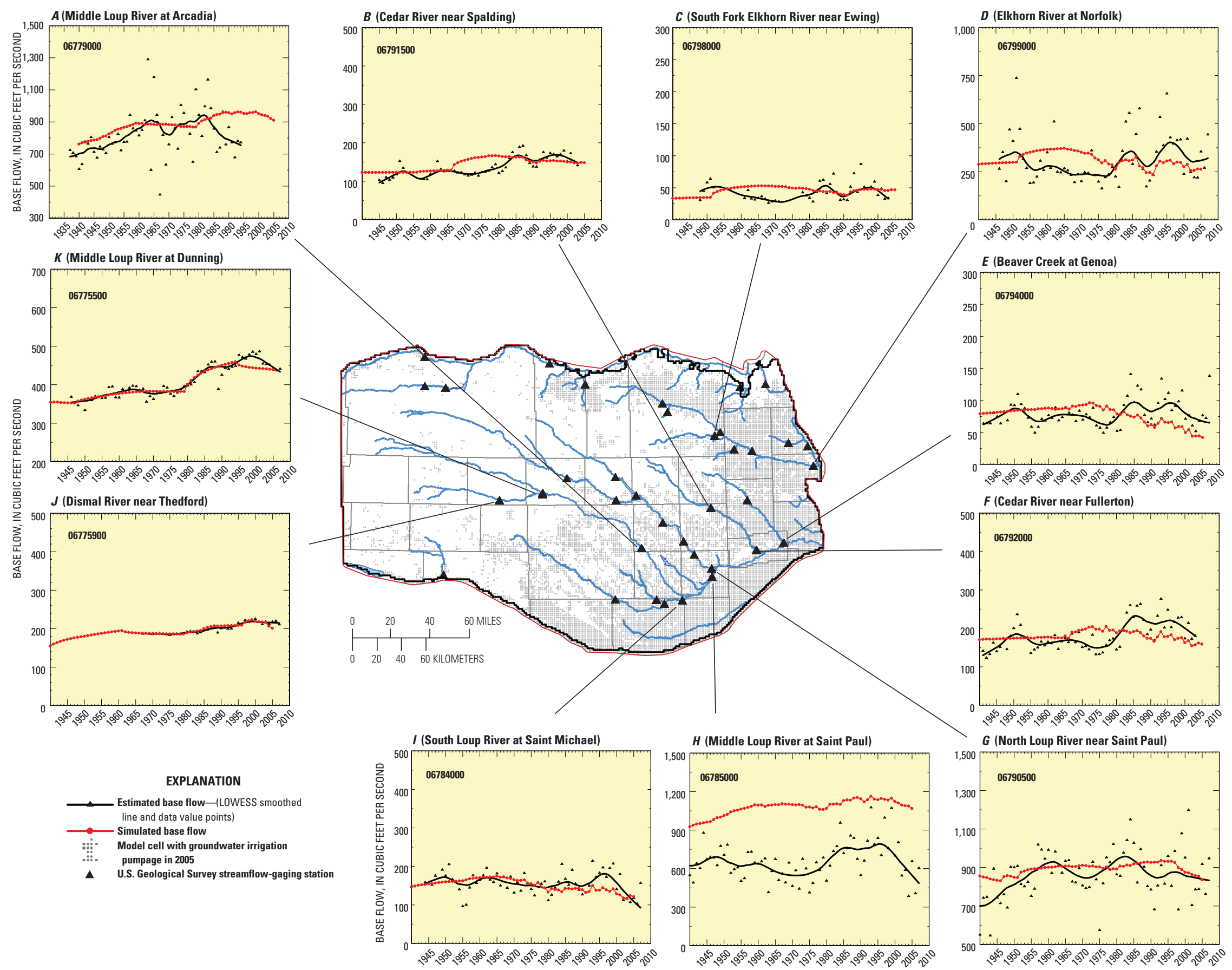

Figure 22. Estimated and simulated annual base flow, 1940 through 2005, Elkhorn and Loup River Basins, Nebraska. 


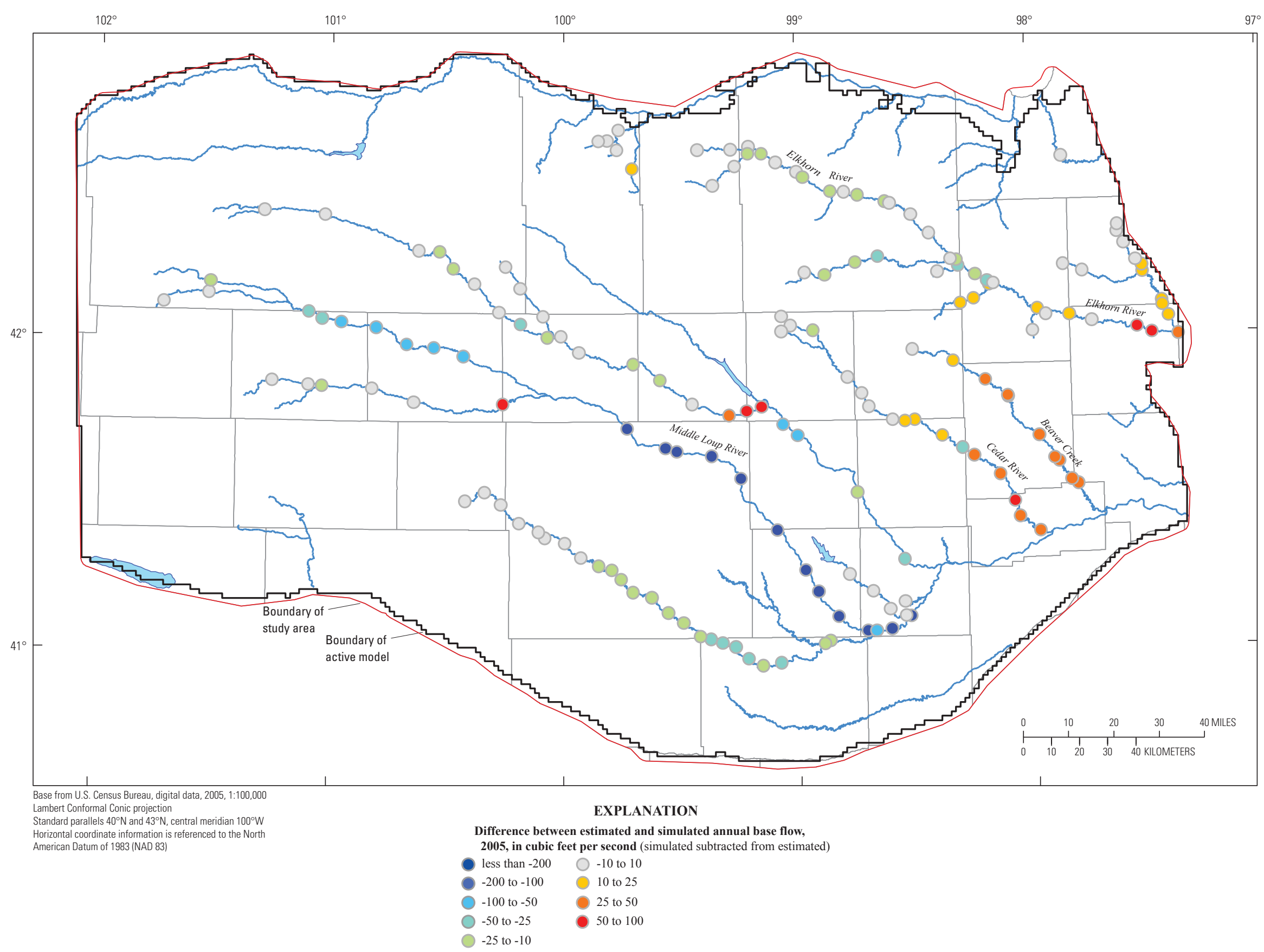

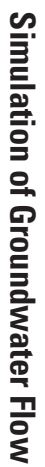

Figure 23. Differences between estimated and simulated annual base flow, 2005, Elkhorn and Loup River Basins, Nebraska. 
Table 6. Simulated groundwater budget by simulation period, Elkhorn and Loup River Basins, Nebraska.

[--, no data]

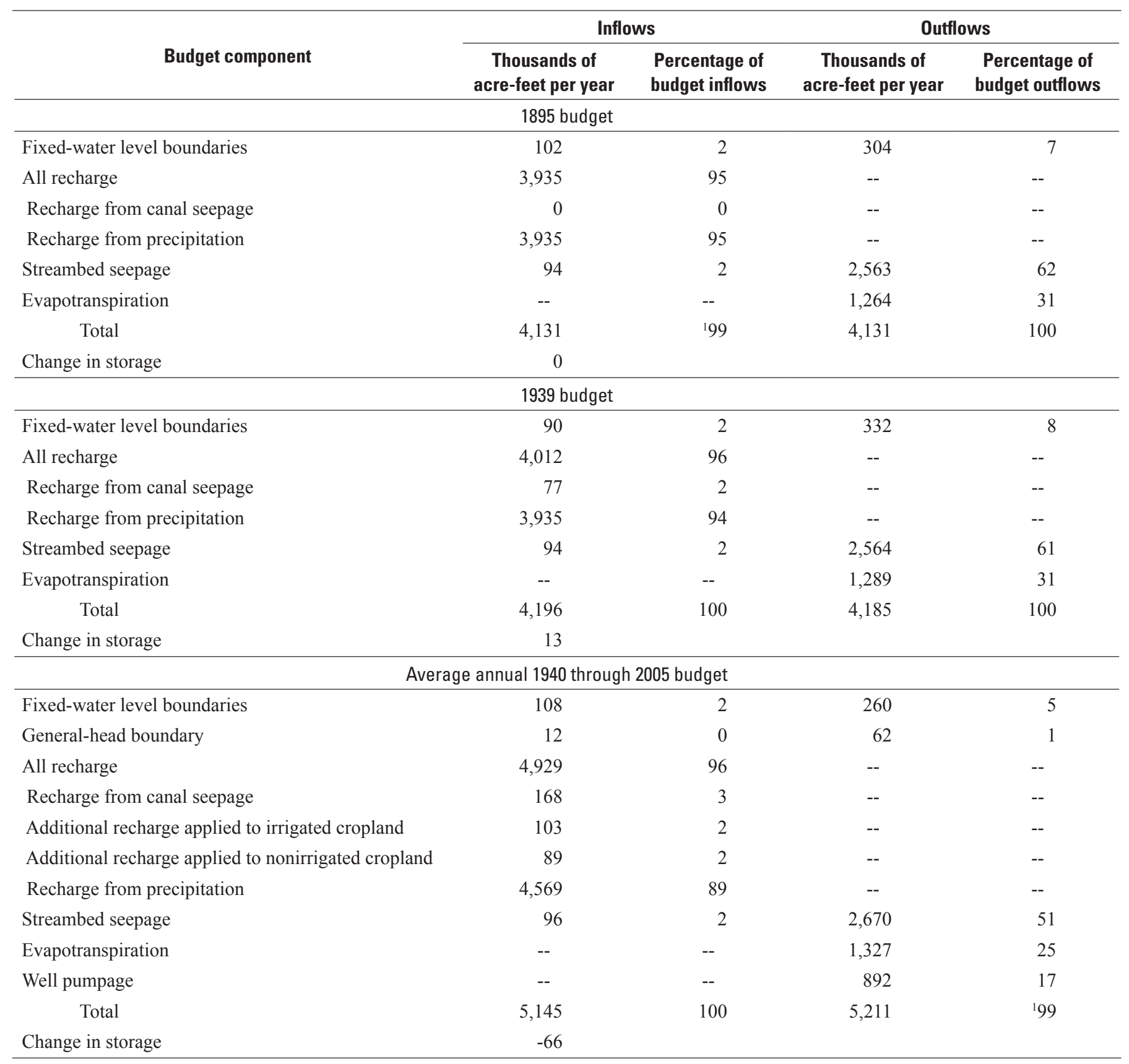

${ }^{1}$ Does not total 100 percent because of rounding.

also was discharged by simulated evapotranspiration (31 percent) and fixed water-level boundaries (8 percent).

Averaged over the 1940 through 2005 period, approximately 89 percent of water entering the simulated aquifer was recharge from precipitation (table 6). Other sources of groundwater were simulated streambed seepage (2 percent), additional recharge applied to irrigated cropland areas ( 2 percent), canal-seepage recharge ( 3 percent), additional recharge applied to nonirrigated cropland areas (2 percent), and fixed water-level boundaries ( 2 percent). Groundwater discharge to stream base flow accounted for about one-half (51 percent) of the water leaving the simulated aquifer. Water also was lost from the aquifer as a result of simulated evapotranspiration (25 percent), well pumpage (17 percent), and fixed water-level boundaries (5 percent). Compared to the 1939 budget, simulated inflows of groundwater in the 1940 through 2005 mean annual budget were larger by about 950,000 acre-feet per year (acre-ft/yr) with 900,000 acre-ft/yr resulting from an increase in all components of recharge. The 1940 through 2005 period budget included approximately an additional 900,000 acre-ft/yr 
of simulated discharge to well pumpage. Discharges to stream boundaries and ET were about the same for both budget periods.

\section{Evaluation of Simulation}

Better estimates of net irrigation pumpage (groundwater pumpage for irrigated cropland minus the estimated excess irrigation water that returns to the aquifer as recharge) or irrigated-cropland recharge (supplemental recharge due to larger soil moisture on irrigated land than nonirrigated land) may provide an important improvement to the simulation. Perhaps the biggest limitation for this simulation was an imbalance between net irrigation pumpage and recharge in some areas where a large percentage of land is used for growing irrigated crops. In several such areas, simulated groundwater-level declines were larger than measured groundwater-level declines (figs. $21 \mathrm{D}$ and $21 \mathrm{H}$ ), indicating that either too much pumpage or too little recharge was simulated. Additionally, simulated base-flow trends were slightly downward while estimated base flow increased slightly for the period having the most irrigated land development (1970 through 2005) (figs. 22D, 22E, and $22 F$ ). The only recognized option for improving the balance between net irrigation pumpage and recharge in the simulation was to increase recharge from precipitation, because neither net irrigation pumpage nor additional irrigatedcropland recharge were calibrated parameters. As with most regional-scale groundwater-flow simulations, the recharge zones used to specify rates of recharge from precipitation were large, and the automated calibration process was not adequate to allow increases to recharge in these areas without degrading the fit to other calibration targets, particularly groundwaterlevel-change targets, within the same recharge zone.

During the initial stages of calibration, irrigated-cropland recharge was a calibrated parameter. During those initial calibration stages, the simulation reproduced measured drawdowns of water level more closely than the final calibrated simulation. However, optimized irrigated-land recharge as determined through the calibration process provided values that appeared too large when compared to previously published information (Dugan and Zelt, 2000; McMahon and others, 2006). It is possible that the large irrigated-cropland recharge value determined during beginning stages of calibration compensated at least partially for too much net irrigation pumpage. If net irrigation pumpage had been allowed to adjust during calibration, it could have been reduced which may have achieved the same effect as increasing irrigatedland recharge.

The measured pumpage data used to adjust crop-irrigation-requirement values only correspond to a short period of record at the end of the simulation period and only represented a few parts of the study area instead of being uniformly distributed across the entire simulation area. In addition, estimated pumpage for irrigation and recharge on agricultural lands was dependent on the land-use data. Land-use maps for
1940 through 2005 were based on the best, most reliable data available but may contain errors. Errors in 1940 through 2005 land use would have caused errors in estimated pumpage for irrigation and in recharge applied to agricultural lands. Moreover, the relations of land-use types to rates of pumping and to rates of recharge also are uncertain.

There is additional uncertainty related to the amount of pumped water that is not used by crops and moves downward to recharge the aquifer. As discussed in the "Well Pumpage" section, the crop-irrigation-requirement values were compared with measured pumpage minus an efficiency factor that accounts for the amount of water that returns to the aquifer during the same stress period. For the phase-two simulation, it was estimated that 20 percent of pumped water returned to the aquifer. Although this was more than twice the rate at which excess pumped water was estimated to return to the aquifer during the phase-one simulation, it is likely that 20 percent is still too low or that a spatially variable rate should be used to increase that percentage in some parts of the study area. Irrigation inefficiency estimates have ranged from as little as 10 percent to as much as 65 percent and depend upon a number of factors including type of irrigation system, soil type, application practices, and cropland slope (Dean Eisenhauer, University of Nebraska-Lincoln, written commun., 1996). GIS data for at least soil type and surface slope are available and could be summarized for recharge zones or similar subdivisions of the model domain to stratify estimated rates of recharge from excess pumpage. Although pumpage and estimates of the amount of pumped water returning to the aquifer were estimated using the best information at hand at the time of calibration, simulations might be further improved if more detailed information about the fate of irrigation water were available or irrigation pumpage values were allowed to adjust during the calibration process.

\section{Sensitivity Analysis}

A sensitivity analysis is a systematic evaluation to identify the parameters that have the greatest potential effect on simulation results (hence, the agreement between simulation results and calibration targets). Parameter sensitivity was assessed as part of the automated calibration process by using the PEST Jacobian matrix (appendix 2). The PEST algorithm uses the sensitivity of simulated calibration-target values to small adjustments in simulation parameters to guide the selection, in sequence, of candidate parameter values. Sensitivity values represent the average amount that simulated values changed when a 1-percent change was made to a parameter value (Hill and Tiedeman, 2007). For each calibration target, the ratio of the amount that the simulated value changed to the 1-percent change in parameter value was scaled by the parameter value and calibration target weight (appendix 2) to obtain a dimensionless value. These dimensionless values can be used to compare the relative sensitivity of different calibration targets. 
Insights into simulation behavior can be gained by graphically investigating maps displaying sensitivity analysis results, such as those shown in figures $24-26$. In these figures, color shading of parameter zones indicates the relative response of the simulation, as measured by the change to all simulated groundwater levels, groundwater-level changes, and base flow, as a result of a fractional change (1 percent) to values of a parameter (Hill and Tiedeman, 2007). Parameters with larger relative sensitivity values will cause larger changes to simulation results than parameters with smaller relative sensitivity values. The results mapped in these figures do not necessarily indicate where in the study area additional hydrogeologic information would be most beneficial for improved simulation results, because the maps are specific to this particular simulation and dependent upon factors such as target weights. An analysis of prediction uncertainty would be a more appropriate basis for assessing the best location for new calibration targets and hydrogeologic data collection.

Simulated 1939 groundwater levels, 1945 through 2005 groundwater-level changes, and base-flow rates had differing sensitivities to changes in $\mathrm{K}_{\mathrm{H}}$ and recharge from precipitation. Simulated groundwater level was most sensitive to changes in recharge from precipitation in the southwestern and in the northeastern parts of the study area (fig. 24). Several recharge parameter zones had few groundwater-level targets within their zone. Simulated groundwater level generally was insensitive for these areas, illustrating the importance of target availability to simulation calibration. In general, varying recharge from precipitation for parameter zones in the western part of the study area had a larger effect on simulated groundwater levels than it did for zones in the eastern part of the study area.

Simulated groundwater-level change was most sensitive to changes in recharge from precipitation in parameter zones corresponding to areas with extensive groundwater irrigation (fig. 25). Simulated groundwater-level change was less sensitive to changes in $\mathrm{K}_{\mathrm{H}}$ values than changes in recharge from precipitation values.

Simulated base flow was more sensitive than groundwater levels or groundwater-level changes to changes in recharge from precipitation and $\mathrm{K}_{\mathrm{H}}$. Base flow had relative sensitivity values of as much as 5.5 (dimensionless), whereas sensitivity values were less than 1.0 for groundwater levels and groundwater-level changes (figs. 24-26). Simulated base flow was most sensitive to recharge from precipitation for parameter zones corresponding to the Dismal River and the upper reaches of the Middle Loup River. The parameter values in these zones have a large effect on simulated base flow primarily because the base-flow targets in these areas were assigned weights that were an order of magnitude larger than other streams of similar size (appendix 2). Large weights were assigned to these targets because preliminary simulations were not able to produce base flows similar to estimated base flows. One reason for the misfit was that downstream base-flow targets were in areas that were influenced by diversions for canals.

\section{Assumptions}

Using MODFLOW and simulation of groundwater-flow systems through finite-difference solution techniques imply many assumptions (Harbaugh, 2005). Some primary assumptions importantly related to ELM study objectives are presented here.

(1) Flow predominantly is horizontal, and the regional aquifer is unconfined. Some evidence exists for strong vertical groundwater flow or confining conditions in some local areas within the study area (Sue Lackey, Conservation and Survey Division, University of Nebraska, oral commun., 2009). However, most regional effects of vertical flow only will be important for simulations with shorter stress periods (such as seasonal or monthly) than were used for this simulation (annual); therefore, the system was represented appropriately for this simulation with a single vertical layer.

(2) The aquifer can be appropriately simulated using grid cells that are $1 \mathrm{mi}$ by $1 \mathrm{mi}$ in size, and aquifer properties are uniform within the area of each grid cell. It is recognized that some system properties change over distances of less than $1 \mathrm{mi}$, but this assumption is appropriate for simulations meant to be used for regional management scenarios.

(3) Sources and sinks of water that have an important effect on the groundwater-flow system, such as streams, pumpage, and recharge, can be appropriately simulated using grid cells that are $1 \mathrm{mi}$ by $1 \mathrm{mi}$ in size. It is recognized that streams in the area actually occupy areas much less than $1 \mathrm{mi}$ wide, but as with assumption 2, this is an acceptable assumption for simulations meant to be used for regional groundwater management scenarios. This assumption also means that this simulation cannot be used to analyze the effects of features that are within 1 mi of streams, because when aggregated to $1 \mathrm{mi}$ cells, those features may be in the same grid cell as the stream. In some situations, the valleys of small streams may not be represented in the inputs for the much larger grid cells containing them, and if the streamflow is controlled by processes that occur within the valley, the simulation may not correctly represent those processes or the stream. Lastly, land-use data, in part, control the pumpage and recharge rates used in the simulations. Although land-use data were available at a finer resolution than the selected grid size, any errors caused by aggregation of these data to 1-mi by 1 -mi grid cells would be undetectable in the simulation results.

(4) The groundwater-flow system, before major anthropogenic effects, was in long-term equilibrium, which can be approximated using a 1,000-year transient stress period. As no substantial anthropogenic effects would have been present in the system before major groundwater development at the system scale, groundwater levels would have represented the integration of climate effects that had occurred during the previous decades or centuries. Therefore, this assumption seems appropriate. 

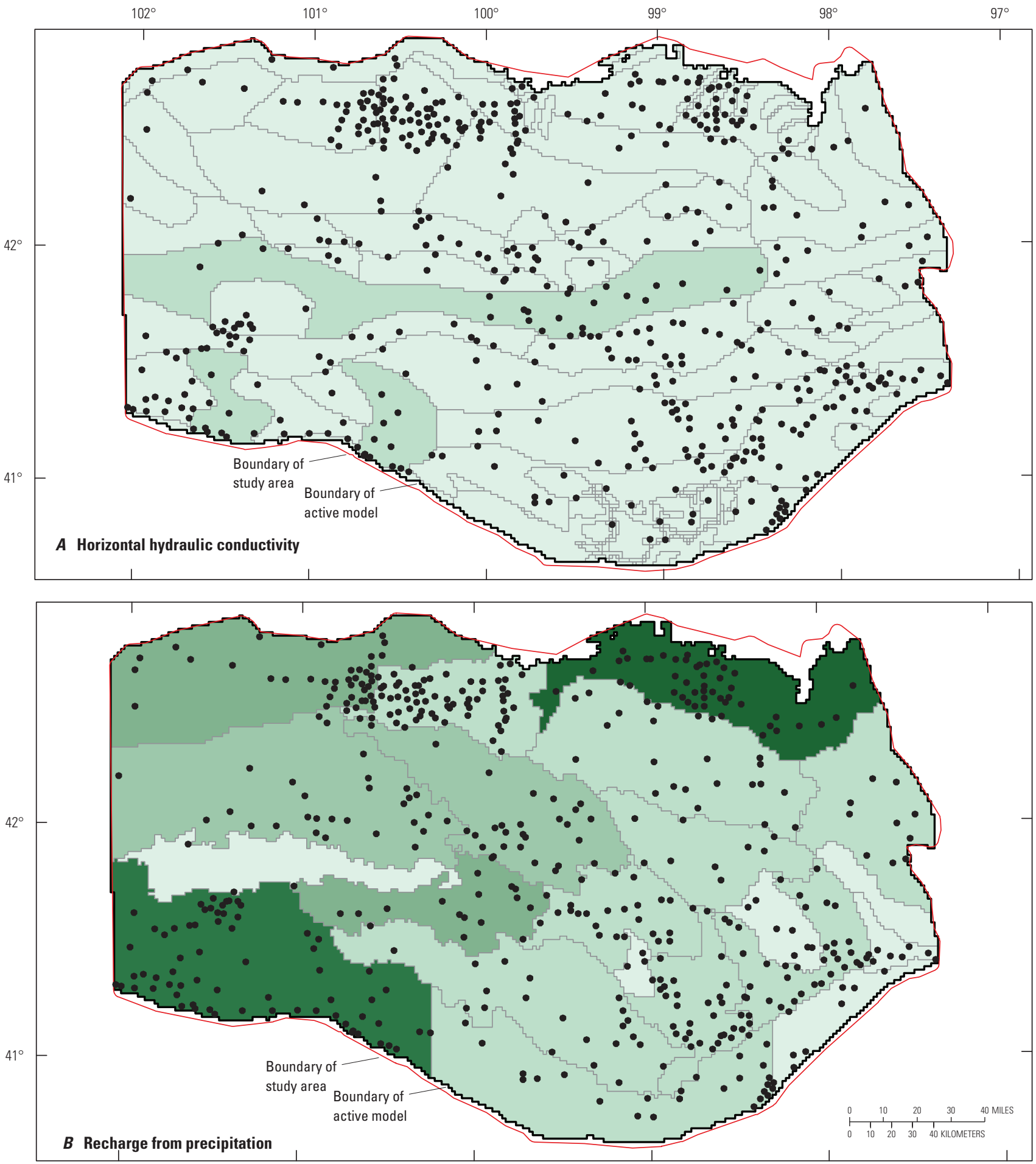

Base from U.S. Census Bureau, digital data, 2005, 1:100,000 Lambert Conformal Conic projection

Standard parallels $40^{\circ} \mathrm{N}$ and $43^{\circ} \mathrm{N}$, central meridian $100^{\circ} \mathrm{W}$ Horizontal coordinate information is referenced to the North American Datum of 1983 (NAD 83)

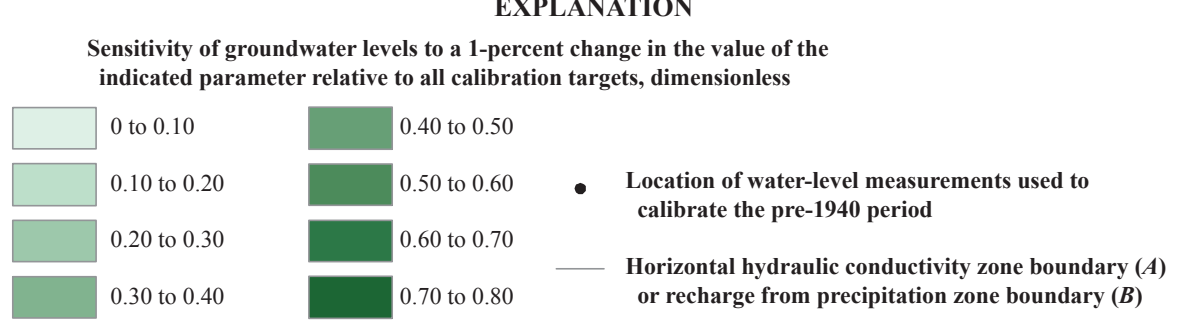

Figure 24. Relative sensitivity of simulated 1939 groundwater levels to a 1-percent change in $A$, horizontal hydraulic conductivity and $B$, recharge from precipitation, Elkhorn and Loup River Basins, Nebraska. 

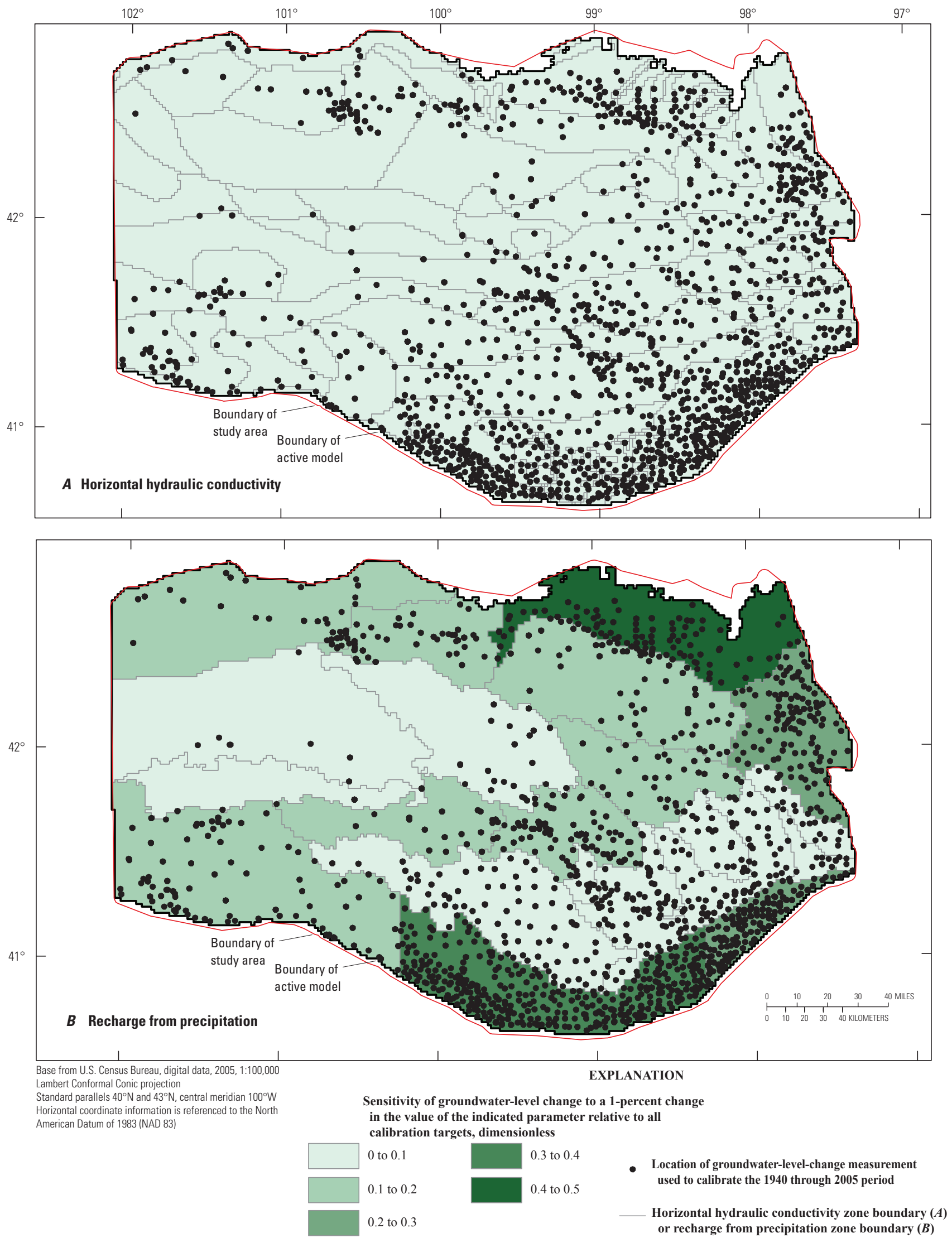

Figure 25. Relative sensitivity of simulated groundwater-level changes throughout the 1940 through 2005 period to a 1-percent change in $A$, horizontal hydraulic conductivity and $B$, recharge from precipitation, Elkhorn and Loup River Basins, Nebraska. 

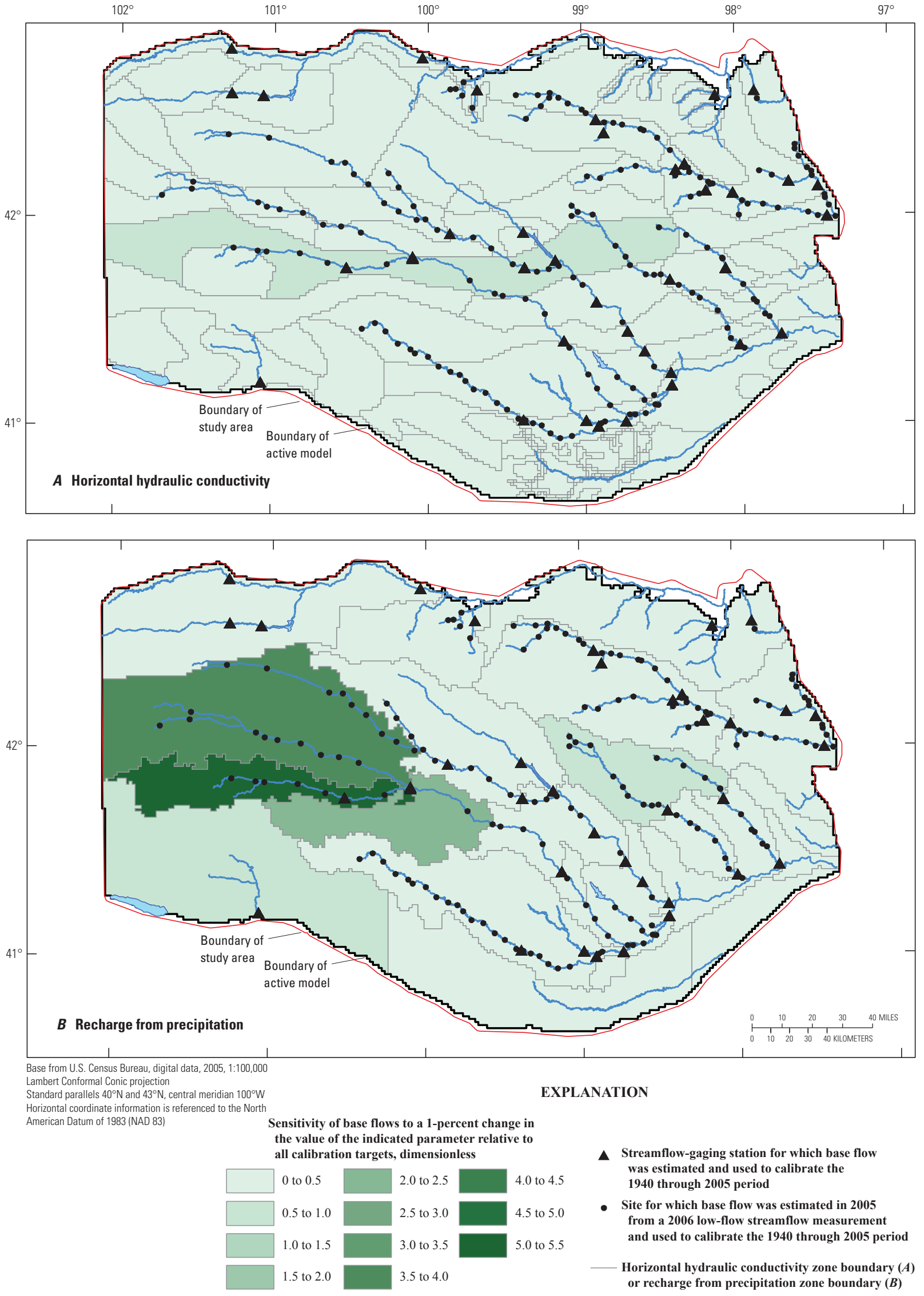

Figure 26. Relative sensitivity of simulated 1940 through 2005 base flow to a 1-percent change in $A$, horizontal hydraulic conductivity and $B$, recharge from precipitation, Elkhorn and Loup River Basins, Nebraska. 
(5) Water that leaks from canals and eventually reaches the water table can be appropriately simulated as recharge. Although this assumption may not be true for short periods, such as days or weeks, or for small areas, it is appropriate for a simulation spanning years and for regional groundwater-flow systems.

\section{Uses and Limitations}

Simulations documented in this report are as accurate as could reasonably be expected given the input data limitations, simulation assumptions, and resources available at the time of the simulation construction and calibration. Although many advanced modeling techniques were used to develop these simulations, their use still has limitations. Most of the important limitations relate either to data used as simulation inputs or data used to estimate simulation inputs. The simulation of the 1940 through 2005 period simulated groundwaterlevel changes and base flows that were similar to measured groundwater-level changes and base flows; therefore, the balance of the pumpage and recharge was considered to be generally correct. Uncertainties in some simulation inputs were not quantifiable and cause uncertainties in the results of the analyses that used the simulation outputs that also are unquantifiable. As might be expected, the usefulness of future simulation periods also depends on how representative the past climate conditions and recent pumpage are of future climate conditions and pumpage. For example, if the future simulation periods are much drier or wetter than 1940-2005 averages, then the analysis results reported would understate or overstate the effects of groundwater irrigation. However, if the amount by which future climate conditions might be drier or wetter than the average of past climate conditions is not known with confidence, it is acceptable to use the average of 1940-2005 climatic conditions for representing future conditions. Other limitations include the inherent uncertainty of simulating complex natural processes using discrete spatial and temporal units.

The goal for developing these simulations was to characterize hydrogeologic processes that importantly regulate regional-scale conditions in order to provide an appropriate tool for water-management decisions. Simulations were not expected to reproduce every detail of the hydrogeologic system; therefore, these simulations are appropriate for analyzing groundwater-management scenarios over spatial scales of multiple counties and time scales of multiple years and are not suited for analysis of small areas or short time periods. However, this calibrated simulation could be used to define boundary conditions for local-scale simulations. The simulation is not appropriate for purposes beyond those for which they were designed. Examples of appropriate uses of the simulation are in the "Simulation of Effects of Groundwater Irrigation on Stream Base Flow" section of this report.

\section{Simulation of Effects of Groundwater Irrigation on Stream Base Flow}

The calibrated simulation was used to determine the effects of groundwater irrigation on future base-flow conditions beyond 2005. A base-flow depletion map was created to represent the spatial distribution of a key management variable in Nebraska, which is the percentage of pumped water that causes base-flow depletion at the end of a 50-year period, assuming that the well pumps continuously at a constant rate. The groundwater-flow simulation was used to predict changes to stream base flow resulting from changes in the number of irrigated acres at the end of a 25-year period (2009 through 2033). A simulation-optimization model was developed to determine the minimum reduction of groundwater pumpage within the Elkhorn River Basin during 2009 through 2033 that would be necessary to maintain various levels of base flow in the Elkhorn River in 2033. The analyses were selected by water managers and scientists from the ELM NRDs, the USGS, the NDNR, and the University of Nebraska. The analyses are not intended to limit the specific plans that might be adopted by regulatory agencies but are intended to improve understanding by demonstrating how base flow is affected by pumpage for irrigation. As is the case for analytical equations or any other method, the results of these numerical analyses can be diagnostic of important system behavior; they are not expected to be absolute or precise predictions of the future state of hydrogeologic system components.

In addition to being dependent on the assumptions and limitations described in the previous sections of the report, the accuracy of the analyses described in this section is dependent on the further assumption that the ELM is a reasonably calibrated representation of the groundwater system and the important processes affecting that system. This is thought to be a reasonable assumption because the simulation produced groundwater levels and groundwater-level changes that generally were similar to measured values and produced simulated base flows that reasonably matched estimated base flows; however, it was noted that the accuracy of the simulation was dependent on the accuracy of estimated pumpage.

\section{Baseline Simulation}

The first step for assessing effects of groundwater irrigation on base flow was to create a "baseline" simulation representing estimated future conditions without any changes to groundwater irrigated acres or pumpage after 2008. The resulting base flow from the baseline simulation then was compared with base flow from a second simulation with modified groundwater irrigated acres or pumpage. The resulting difference in base flow indicated the effect of the change in groundwater irrigation. 
A baseline simulation was created for the 2006 through 2055 time period. Simulated groundwater levels from the end of the calibration-period simulation were used as initial groundwater levels in simulating 2006. Future pumpage and additional recharge applied to irrigated-cropland areas were estimated using 2005 land-use data and locations of irrigation wells registered with the NDNR during 2006, 2007, and 2008 (Jesse Bradley, Nebraska Department of Natural Resources, written commun., 2009). The number of irrigated acres added for each new well (122.1 acres) was set initially to the median size of fields irrigated with a center-pivot irrigation system within the study area (Jesse Bradley, Nebraska Department of Natural Resources, written commun., 2009). Because new wells were sometimes located in grid cells that already contained irrigated acres as of 2005, it was necessary in such cases to reduce the number of acres associated with the new wells so that the total number of irrigated acres within a cell was realistic. A maximum of 560 irrigated acres was allowed in each 640-acre grid cell; assuming that, on average, 80 acres in each grid cell would not be irrigated. The irrigated acreage associated with new wells was reduced in 38 grid cells because the total irrigated acres would have exceeded 560 acres in a grid cell.

Net irrigation pumpage associated with the new acres from 2006, 2007, and 2008 was estimated using similar methods as discussed in the "Well Pumpage" section of this report. Crop-water demand associated with the new acres was assumed to be $25.5 \mathrm{in} / \mathrm{yr}$, the amount of water needed to grow corn, because information regarding the crop types associated with these new acres was not available for 2006-08, and it was assumed that most newly irrigated cropland would be planted in corn. The crop-water requirement for corn represents a conservative estimate of the amount of water that would be needed by crops grown on these acres, because corn generally requires more water than other crops.

The number of irrigated acres for years 2009 through 2055 was set to the total number of irrigated acres in 2008 . Net irrigation pumpage for 2009 through 2055 was estimated by subtracting the average depth of growing-season effective precipitation from 1940 through 2008 from the crop-water demand in 2008 and then applying the adjustment factors used during the calibration period (table 1). This method represents an improvement from the phase-one approach to simulating pumpage for 2006 through 2055, which was to subtract the averaged volume of growing-season effective precipitation for 1940 through 2005 from the crop-water demand volume in 2005. Average estimated net irrigation pumpage for 2009 through 2055 is shown in figure 27. Differences between figures 6 and 27 are expected because net irrigation pumpage is calculated somewhat differently for the two figures; values shown on figure 6 represent an average of crop-water demand minus growing-season effective precipitation calculated on a yearly basis, and values shown on figure 27 represent 2008 crop-water demand minus the average growing-season effective precipitation from 1940 through 2008. Average yearly net irrigation pumpage volume for 2009 through 2055 was about
$1,863,000$ acre-ft/yr, slightly less than the simulated irrigation pumpage volume for $2005(1,909,000$ acre-ft). This corresponds to a slightly larger average growing-season effective precipitation calculated for groundwater irrigated areas in the study area during the 2009 through 2055 period (15.9 inches) than for 2005 (15.4 inches).

Because future recharge rates were unknown, recharge was held constant from 2006 through 2055 at the average 1940 through 2005 rates of recharge from precipitation, as determined during the calibration process. All other simulation inputs, including canal-seepage and cropland supplemental recharge rates, were the same as those used in year 2005 of the calibrated simulation.

Simulated base flow during 2055, resulting from the baseline simulation, is shown in figure 28 and table 7. Simulated base flow is zero in 2055 for parts of Beaver Creek, Cache Creek, Cedar Creek, Clearwater Creek, Oak Creek, Turkey Creek, and Willow Creek. Most of these streams are small, and generally had less than $20 \mathrm{ft}^{3} / \mathrm{s}$ of observed base flow in autumn 2006 (Peterson and Strauch, 2007). Simulated base flow in these smaller streams either becomes absent in the early part of the future simulation (within 10 years) or, in some cases, was absent during the calibration period (1895 through 2005) simulation. A higher level of uncertainty was associated with base flows of small streams simulated during the calibration period; therefore, there is substantial uncertainty about simulated future base flows of those streams. The largest stream (by mean flow rate) having segments with no simulated base flow in 2055 is Beaver Creek. This stream maintains simulated base flow throughout its length until 2046.

Most streams had less simulated base flow in 2055 than in 2005 (table 7). Streamflow-gaging stations along the Elkhorn River had the largest reduction to simulated base flow. The Elkhorn River at Norfolk streamflow-gaging station had about $170 \mathrm{ft}^{3} / \mathrm{s}$ (or 64 percent) less simulated base flow in 2055 than in 2005. Downstream streamflow-gaging stations on the Cedar River and Beaver Creek had about $40 \mathrm{ft}^{3} / \mathrm{s}$ less base flow in 2055 than in 2005, reductions of 24 and 93 percent, respectively. Several streamflow-gaging stations along the North Loup River had more simulated base flow in 2055 than in 2005.

\section{Base-Flow Depletion Percentage for a 50-Year Period}

Base-flow depletion predictions are used for regulatory purposes in the State of Nebraska to define "hydrologically connected" areas where groundwater withdrawals substantially affect streamflows within a certain time period (Nebraska Department of Natural Resources, 2005b, 2006). Base-flow depletion occurs when a pumping well reduces groundwater discharge to streams or causes additional stream water to leak from the streambed (Jenkins, 1968). It is a function of time, location of the pumping well, aquifer transmissivity and storage coefficient, and the geometry of the aquifer and streams. When a well begins to pump water, the source 


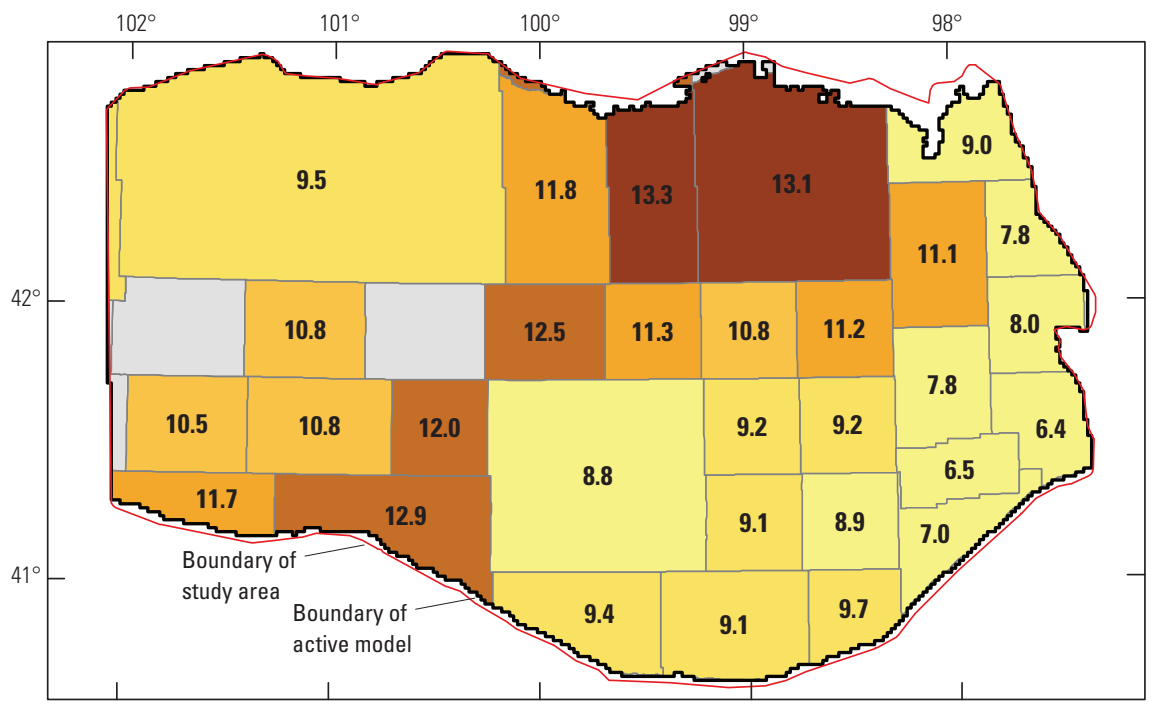

\section{EXPLANATION}

Average annual net irrigation pumpage for all crops, 2009 through 2055, in acre-inches/acre 9.0 or less

9.0 to 10.0

10.0 to 11.0

11.0 to 12.0

12.0 to 13.0

13.0 to 14.0

More than 14.0

No crops reported

\section{EXPLANATION}

Average annual net irrigation pumpage for corn, 2009 through $\mathbf{2 0 5 5}$, in acre-inches/acre 9.0 or less

9.0 to 10.0

10.0 to 11.0

11.0 to 12.0

12.0 to 13.0

13.0 to 14.0

More than 14.0

No crops reported

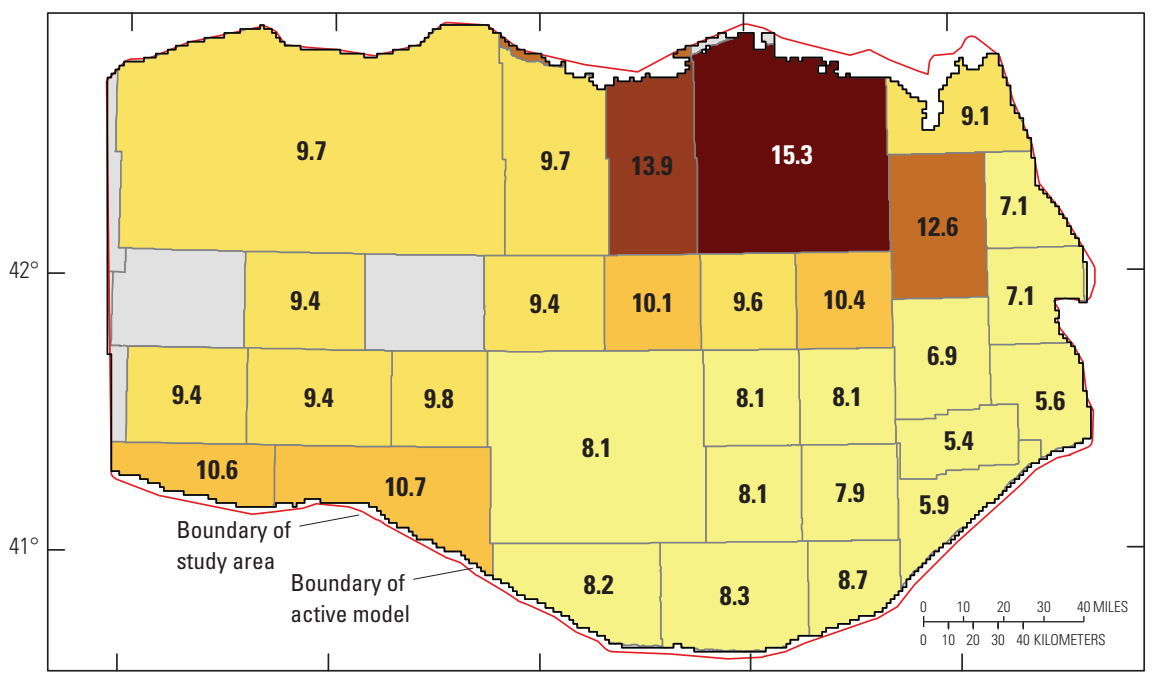

\section{EXPLANATION}

Average annual net irrigation pumpage for soybeans, 2009 through 2055, in acre-inches/acre 9.0 or less

9.0 to 10.0

10.0 to 11.0

11.0 to 12.0

12.0 to 13.0

13.0 to 14.0

More than 14.0

No crops reported

Figure 27. Average annual net irrigation pumpage by county, 2009 through 2055, Elkhorn and Loup River Basins, Nebraska. 


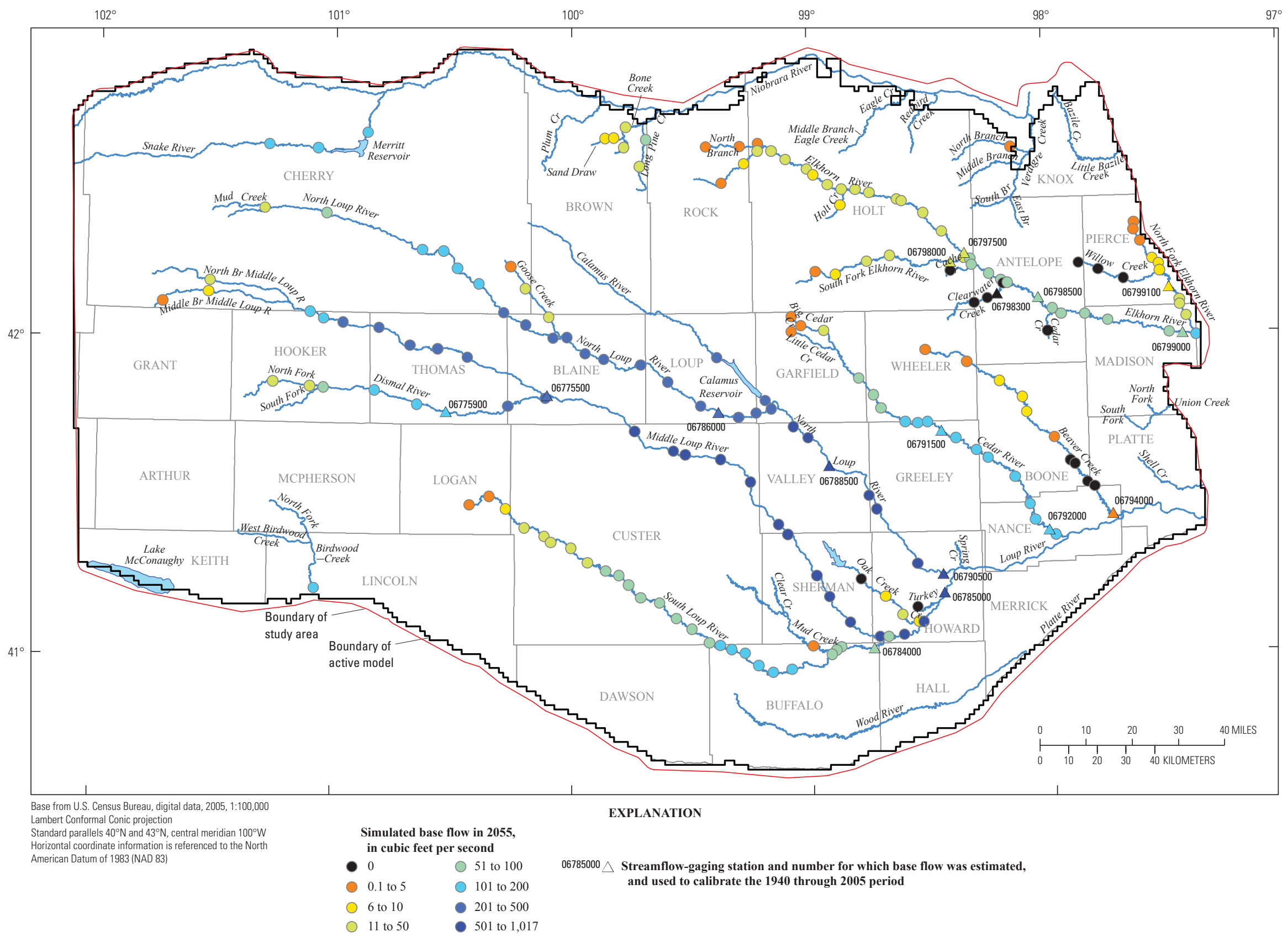

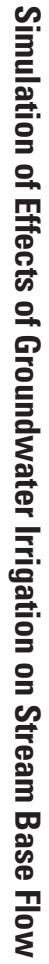

Figure 28. Simulated base flow in 2055 from the baseline simulation, Elkhorn and Loup River Basins, Nebraska. 
Table 7. Estimated and simulated base flow at selected streamflow-gaging stations, Elkhorn and Loup River Basins, Nebraska.

[Values are in cubic feet per second.]

\begin{tabular}{|c|c|c|c|c|}
\hline \multirow{2}{*}{$\begin{array}{l}\text { U.S. Geological Survey } \\
\text { streamflow-gaging station and number } \\
\text { (fig. 28) }\end{array}$} & \multirow{2}{*}{$\begin{array}{c}\text { Estimated base flow } \\
2005\end{array}$} & \multicolumn{3}{|c|}{ Simulated baseline base flow } \\
\hline & & 2005 & 2033 & 2055 \\
\hline \multicolumn{5}{|c|}{ Elkhorn River Basin } \\
\hline Elkhorn River at Ewing (06797500) & 83.7 & 79.5 & 39.2 & 29.8 \\
\hline South Fork Elkhorn River at Ewing (06798000) & 39.1 & 46.7 & 38.1 & 37.7 \\
\hline Clearwater Creek near Clearwater (06798300) & 27.8 & 7.6 & 0.0 & 0.0 \\
\hline Elkhorn River at Neligh (06798500) & 180.6 & 174.0 & 94.0 & 76.8 \\
\hline Elkhorn River at Norfolk (06799000) & 355.3 & 263.3 & 124.4 & 93.6 \\
\hline North Fork Elkhorn River near Pierce (06799100) & 55.4 & 47.4 & 13.0 & 9.6 \\
\hline \multicolumn{5}{|c|}{ Loup River Basin } \\
\hline Middle Loup River at Dunning (06775500) & 438.6 & 439.3 & 420.7 & 418.8 \\
\hline Dismal River near Thedford (06775900) & 217.6 & 200.9 & 200.8 & 199.6 \\
\hline South Loup River at St. Michael (06784000) & 118.1 & 121.6 & 101.7 & 93.4 \\
\hline Middle Loup River at St. Paul (06785000) & 938.6 & $1,067.8$ & $1,033.6$ & $1,017.3$ \\
\hline North Loup River at Taylor (06786000) & 467.6 & 440.0 & 457.9 & 458.9 \\
\hline North Loup River at Ord (06788500) & 618.1 & 773.0 & 816.2 & 818.3 \\
\hline North Loup River near St. Paul (06790500) & 917.8 & 836.4 & 877.1 & 878.3 \\
\hline Cedar River near Spalding (06791500) & 174.8 & 148.2 & 136.9 & 134.4 \\
\hline Cedar River near Fullerton (06792000) & 173.5 & 170.3 & 135.2 & 128.7 \\
\hline Beaver Creek at Genoa (06794000) & 76.7 & 42.3 & 8.6 & 3.0 \\
\hline
\end{tabular}

of that water is initially from storage, resulting in groundwater-level declines near the well (Theis, 1940). As pumping continues, the 3-dimensional zone of effect of the pumping well can expand, potentially causing increased inflow to the aquifer (such as from streamflow) and decreased outflow from the aquifer (such as to evapotranspiration or stream base flow). The relation between storage depletion (water from storage as groundwater-level declines) and stream base flow or evapotranspiration depletion with time is illustrated in figure 29.

Base-flow depletion maps show simulated depletion as a function of pumping-well location. The base-flow depletion caused by the pumping of one additional hypothetical well at a continuous rate of $1 \mathrm{ft}^{3} / \mathrm{s}$ from 2006 through 2055 was determined one grid cell at a time for 22,208 grid cells. Using each of these grid cells as the location of the added well, the simulation was run, and the total base-flow volume during the simulation was recorded. The reduction in base flow caused by the addition of the one hypothetical pumping well was then calculated as the difference in total base-flow volume between the baseline simulation and the hypothetical pumping-well simulation during the 50-year period. The volume of that reduction was divided by the total volume pumped by the hypothetical well during the 50 -year period to calculate the base-flow depletion caused by that well, and expressed as a percentage of total pumpage. The hypothetical well then was moved sequentially to the next grid cell, and the process was repeated. Each of those 22,208 simulations was constructed using the 2006 through 2055 baseline simulation. Other than the hypothetical pumping well, all simulation inputs, including all wells, were the same as those of the baseline simulation.

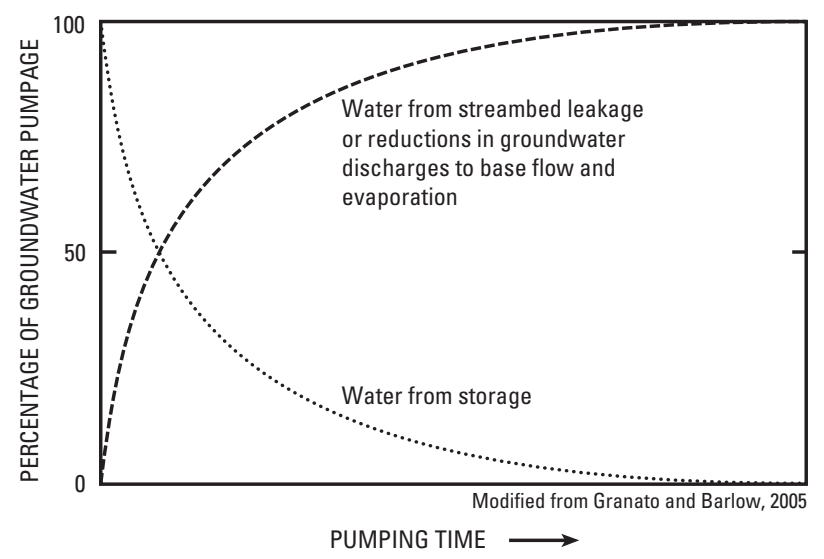

Figure 29. Sources of water to a pumping well as a function of time. (Modified from Granato and Barlow, 2005). 
Because the simulation response to the pumping rate of a well is nearly linear in most parts of the study area, the predicted depletion generally is not sensitive to the pumping rate selected for the hypothetical well; however, the sensitivity of predicted depletion to pumping rate was tested for this simulation. Alternative pumping (water removed from the aquifer) rates of $10,1.0$, and $0.1 \mathrm{ft}^{3} / \mathrm{s}$ and injection (water pumped into the aquifer) rates of $0.1,1.0$, and $10 \mathrm{ft}^{3} / \mathrm{s}$ were tested for the hypothetical well. These tests were simulated for five randomly selected locations, and the maximum change in depletion percentage was less than 2 percent from the baseline simulation. However, at a location where the saturated thickness was small (about $50 \mathrm{ft}$ ), the change in depletion percentage was about 35 percent when the hypothetical well pumping rate was set to $10 \mathrm{ft}^{3} / \mathrm{s}$. At another location near a drying stream, the change in depletion percentage reached about 10 percent if the hypothetical well injected $10 \mathrm{ft}^{3} / \mathrm{s}$ of water, and thus prevented the stream's simulated base flow from completely disappearing.

Changes in simulated base flow caused by the addition of the hypothetical well were evaluated only in the Elkhorn and Loup River Basins; depletions caused to streams outside of the Elkhorn and Loup River Basins, such as to the Niobrara River, were not included. Simulated base-flow depletion as a percentage of well pumpage is shown as a function of well location in figure 30. Mapped base-flow depletions indicate that less than 10 percent of pumped water corresponds to baseflow depletion in areas that are about $10 \mathrm{mi}$ or more from the Elkhorn and Loup Rivers and their tributaries after a 50-year period; however, base-flow depletion as a function of distance to streams was variable. Differences in depletions along every stream and across the area were caused by heterogeneity in simulation inputs and by differences in the simulated hydrology of the system. Furthermore, because the simulation does not manufacture water to supply the hypothetical well, the water pumped by that well must be balanced by some other change in the system. In some cases, such as for grid cells along parts of the Elkhorn and North Loup Rivers, the hypothetical well reduced the amount of groundwater removed by evapotranspiration instead of depleting base flow, so the base-flow depletion was less than in areas without evapotranspiration of groundwater (fig. 31A). Although depletion of water from aquifer storage was expected as an initial response to the hypothetical pumping well in all areas (fig. 29), pumpage of the hypothetical well caused a more substantial change to simulated storage (larger depletion values) along most parts of Beaver Creek than was simulated along other streams for the 2006 through 2055 period (fig. $31 B$ ). This result may be caused at least partly by the section of Beaver Creek that received no base flow for the last several years of the baseline simulation (fig. 28).

Depletions of simulated base flow caused by the hypothetical well pumpage would have been larger than shown in areas where there was little base flow remaining at the end of the baseline simulation. No base-flow depletion can occur if simulated baseline base flow is absent; therefore, base-flow depletion as a percentage of the volume pumped in 50 years declines from the time the simulated stream goes dry in the baseline simulation until the end of the analysis period. If runoff were considered for streams with no base flow, part of that runoff also could be lost to the aquifer, increasing the total streamflow depletion above the base-flow depletion calculated in this analysis.

The phase-two base-flow depletion map differs from the phase-one map (Peterson and others, 2008) in several ways: (1) smaller grid cells in the phase-two simulation allow for a more refined representation of predicted changes to baseflow depletion as a function of distance to simulated streams; (2) simulated base-flow depletion is greater than in phase one in several areas, such as along the Elkhorn River, North Fork Elkhorn River, and Beaver Creek; and (3) simulated baseflow depletion is less than in phase one in several areas, such as between the upper reaches of the Middle and North Loup Rivers in Cherry County, the northeastern corner of Sherman County, and in the center of Custer County.

Several simulation characteristics can help explain greater base-flow depletion values near the Elkhorn River, North Fork Elkhorn River, and Beaver Creek. In the phaseone baseline simulation, the North Fork Elkhorn River, most of Beaver Creek, and parts of the Elkhorn River had little or no simulated base flow by 2055; therefore, simulated baseflow depletion was less than it would have been if baseline base flow had not declined to zero in parts of those streams. In 2055 of the phase-two baseline simulation, the North Fork Elkhorn River has simulated base flow of up to $58 \mathrm{ft}^{3} / \mathrm{s}$, only a small part of Beaver Creek does not have base flow, and all Elkhorn River stream reaches have base flow (fig. 28). If predicted base flow in the phase-two baseline simulation is a better representation of future conditions (more streams have base flow in 2055), then the phase-two simulation has produced a more accurate representation of base-flow depletion during 2006-2055. The phase-two simulation also includes improved estimates of where ET from groundwater is occurring. Occurrence of simulated ET in the phase-two simulation was based upon the location of surface water, wetlands, or riparian forest and woodlands in a 2005 land-use map (fig. 10). ET from groundwater in the phase-one simulation was specified to occur near major streams and in large generalized regions containing wetlands or riparian areas (Peterson and others, 2008; fig. 14). South of the upper reaches of the Elkhorn River, pumpage of the hypothetical well caused larger depletions of simulated ET instead of base flow in the phaseone simulation.

Artificial simulation boundaries potentially can introduce error into base flow, ET, and storage-depletion calculations. Pumpage can cause depletion to fixed-water level boundaries (fig. 2) instead of base flow, ET, or storage, thereby underestimating actual depletion to base flow, ET, or storage; therefore, base-flow, ET, and storage depletion were not reported for grid cells that had 10 percent or more depletion of fixed-water level boundaries. This was the case for parts of Madison and Platte Counties in the east and for parts of Cherry and Grant Counties in the west (figs. 30 and 31). Zero-flow boundaries can cause 


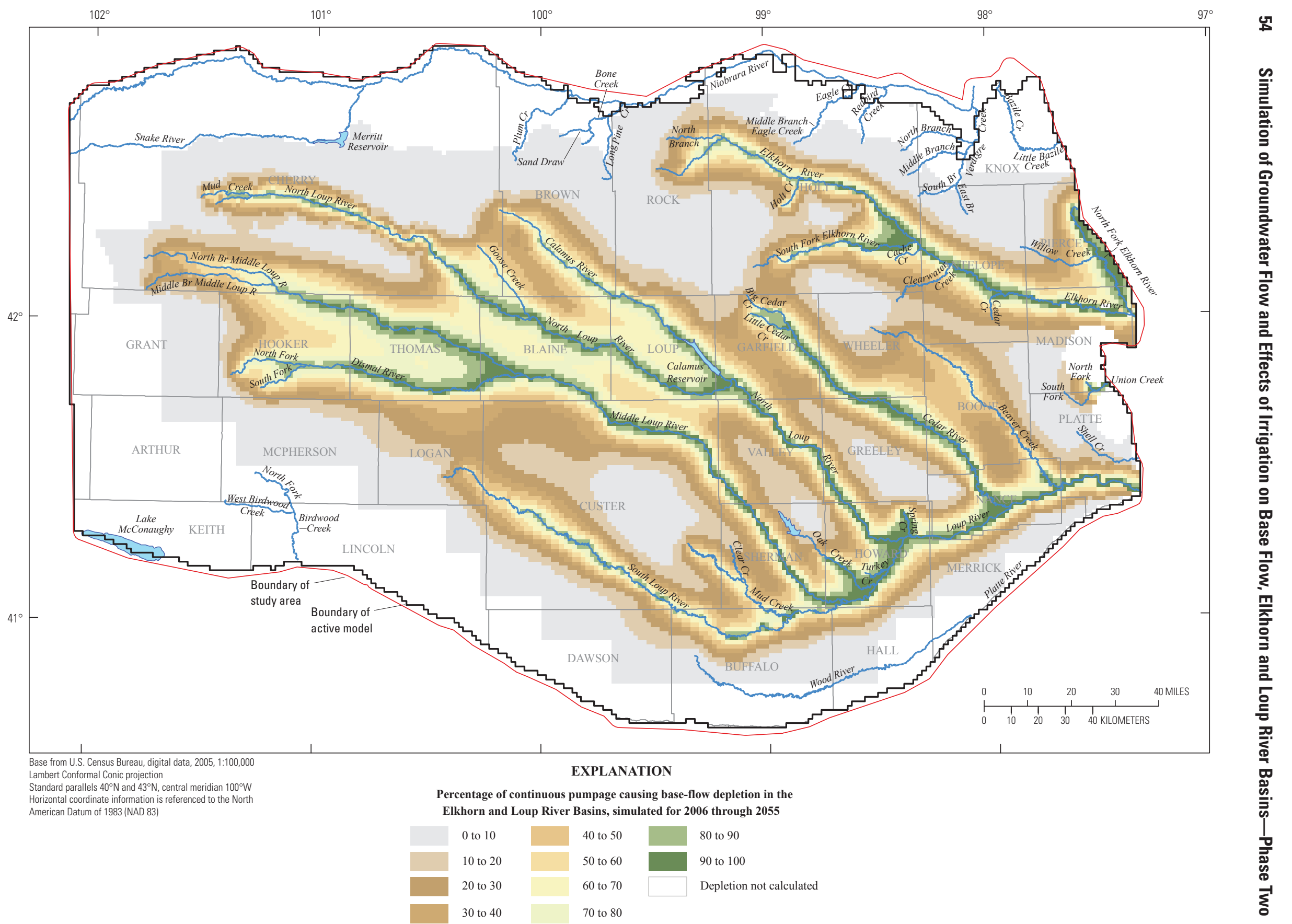

Figure 30. Percentage of hypothetical well pumpage corresponding to simulated base-flow depletion in the Elkhorn and Loup River Basins, for 2006 through 2055. 

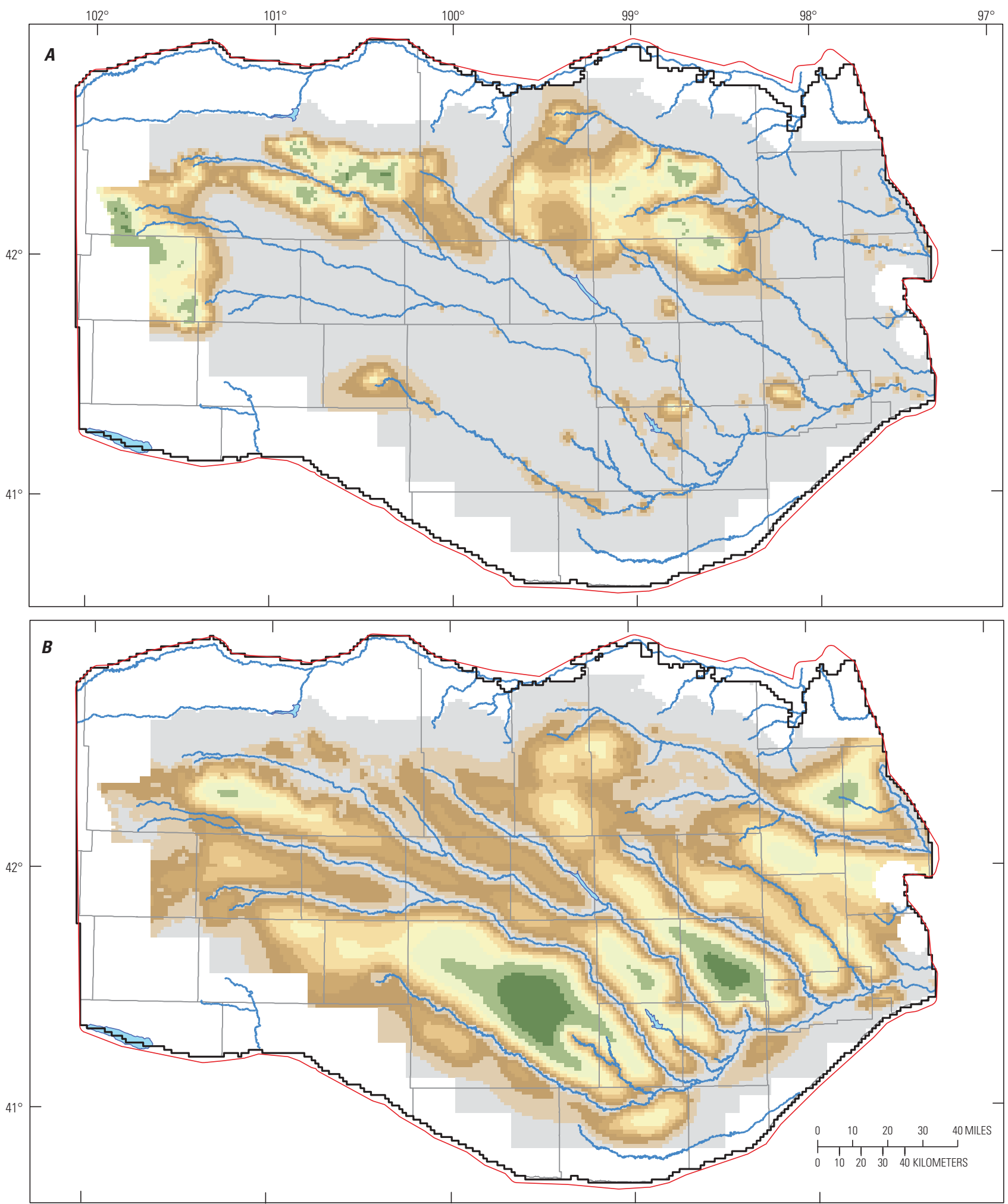

Base from U.S. Census Bureau, digital data, 2005, 1:100,000 Lambert Conformal Conic projection

Standard parallels $40^{\circ} \mathrm{N}$ and $43^{\circ} \mathrm{N}$, central meridian $100^{\circ} \mathrm{W}$ Horizontal coordinate information is referenced to the North American Datum of 1983 (NAD 83)

\section{EXPLANATION}

Percentage of continuous pumpage causing depletion in the Elkhorn and Loup River Basins, simulated for 2006 through 2055

\begin{tabular}{l|l|l|l|l|}
0 to 10 & 30 to 40 & 60 to 70 & 90 to 100 \\
\hline 10 to 20 & 40 to 50 & 70 to 80 & Depletion not calculated \\
20 to 30 & 50 to 60 & 80 to 90 &
\end{tabular}

Figure 31. Percentage of hypothetical well pumpage corresponding to simulated depletion of $A$, evapotranspiration from groundwater and $B$, groundwater storage in the Elkhorn and Loup River Basins, for 2006 through 2055. 
Simulation of Groundwater Flow and Effects of Irrigation on Base Flow, Elkhorn and Loup River Basins-Phase Two

depletion to base flow, ET, and storage to be overestimated. Depletion estimates were calculated away from most zero-flow boundaries with the exception of parts of Madison and Pierce Counties. Base-flow, ET, and storage depletion estimates close to zero-flow boundaries, such as those near the North Fork Elkhorn River, may be less reliable if the assumption that groundwater does not flow across those boundaries is not satisfied.

\section{Effect on Base Flow of Decreasing or Increasing Irrigated Acres}

Future changes to base flow from changes to the number of irrigated acres were evaluated for a 25-year period (2009 through 2033). This time period was chosen because it corresponds to the management time horizon used by the NDNR. The effect of changing irrigated acres composites the individual effects of changing the amount of groundwater pumpage and the amount of additional recharge applied to cropland as acres shift from the nonirrigated rate to the irrigated rate, or the converse shift. No attempt was made to determine these individual effects on base flow, that is from changing groundwater pumpage only or changing additional recharge applied to cropland only.

\section{Effect of Decreased Irrigated Acres}

The calibrated groundwater-flow simulation was used to determine the effect of reducing irrigated acres within the Upper and Lower Loup NRDs and the Upper and Lower Elkhorn NRDs. In this scenario, the number of irrigated acres in 2008 in each of the grid cells within those NRDs was reduced by 10 percent, and the affected acres were simulated as nonirrigated cropland. This total reduction in irrigated land of about 120,000 acres resulted in a 5-percent reduction to simulated pumpage for irrigation across the whole study area, as well as a reduction to the amount of additional recharge that was applied to surface-water- and groundwater-irrigated acres. The reduced pumpage and recharge scenario was simulated for 2009 through 2033. Pumpage and recharge for 2006 through 2008 were set equal to their baseline simulation values.

Simulated base flow from the decreased-acres simulation was compared with simulated 2033 base flow from the baseline simulation (fig. 32). The largest increases to simulated base flow were predicted for downstream locations along the Elkhorn and Middle Loup Rivers, demonstrating the cumulative effects of reducing irrigated acres throughout the drainage basin. In addition, the number of irrigated acres generally is larger in the south and east, coinciding with downstream locations. Simulated base flow was predicted to increase by a maximum of $13.0 \mathrm{ft}^{3} / \mathrm{s}$ (1.3 percent) in the Loup River Basin and by as much as $23.8 \mathrm{ft}^{3} / \mathrm{s}$ (17 percent) in the Elkhorn River Basin. The largest increases to simulated base flow as a percentage of baseline base flow were observed on Beaver Creek (as much as 80 percent), the North Fork Elkhorn River (as much as 24 percent), and the Elkhorn River (as much as 17 percent).

\section{Effect of Increased Irrigated Acres}

According to Nebraska Legislative Bill 483 (Nebraska State Legislature, 2009), NRDs not designated as "fully appropriated" are authorized to allow increases in irrigated acres in hydrologically connected areas. Changes to simulated base flow as a result of potential future increases in groundwater-irrigated acres within the Lower Elkhorn, Lower Loup, Lower Platte North, Upper Elkhorn, and Upper Loup NRDs were evaluated using the calibrated simulation. Groundwaterirrigated acres were increased by as much as 2,500 acres each year during 2009 through 2012, for a maximum increase of 10,000 acres per NRD within areas predicted to have 10 percent or more of the pumped water from each new pumping well supplied from depletion of base flow (fig. 30).

Simulated location of this future groundwater development for 2009 through 2012 was estimated in each NRD using requests received by each NRD from landowners for additional irrigated acres, local knowledge of where future development was most likely, and the location of nonirrigated cropland. In general, the number and location of newly irrigated acres for 2009 were determined from existing landowner requests, but requests for additional irrigated acres for 2010 through 2012 had not been received. Therefore, the number of requested additional irrigated acres in 2009 was used to predict how many acres would be developed in 2010 through 2012 , by assuming that the number of acres requested in each of those years would be similar to the number requested in 2009. Because the location of the additional irrigated acres for 2010 through 2012 was largely unknown, acres for those years were added in areas where irrigated agricultural development is expected by the NRDs. Irrigated acres were added only where nonirrigated cropland already existed, assuming that nonirrigated cropland would be converted to irrigated cropland before other lands would be used as irrigated cropland.

From 2009 through 2012, almost 25,000 irrigated acres were added to the simulation (fig. 33), a 1-percent increase from the number of acres irrigated in 2008. Net irrigation pumpage associated with the converted acres was estimated using similar methods as discussed in the "Well Pumpage" section of this report. Simulated pumpage for the converted acres was estimated assuming that corn would be grown on these acres. Simulated net irrigation pumpage in the increasedacres scenario was about 21,000 acre-ft/yr greater than net pumpage in the baseline simulation. Simulated recharge values were increased by about 1,000 acre-ft/yr to account for the amount of additional recharge associated with converting nonirrigated cropland to irrigated cropland.

After 25 years, simulated (2033) base flow decreased by a maximum of $2.9 \mathrm{ft}^{3} / \mathrm{s}$ (less than 1 percent) in the Loup River Basin and by as much as $6.9 \mathrm{ft}^{3} / \mathrm{s}$ ( 5 percent) in the Elkhorn River Basin (fig. 33). Changes to base flow were related to the proximity of the converted acres to a simulated stream. Conversion of acres located closer to streams will affect base flow within a shorter time period than will additional irrigated acres located farther away from streams. 


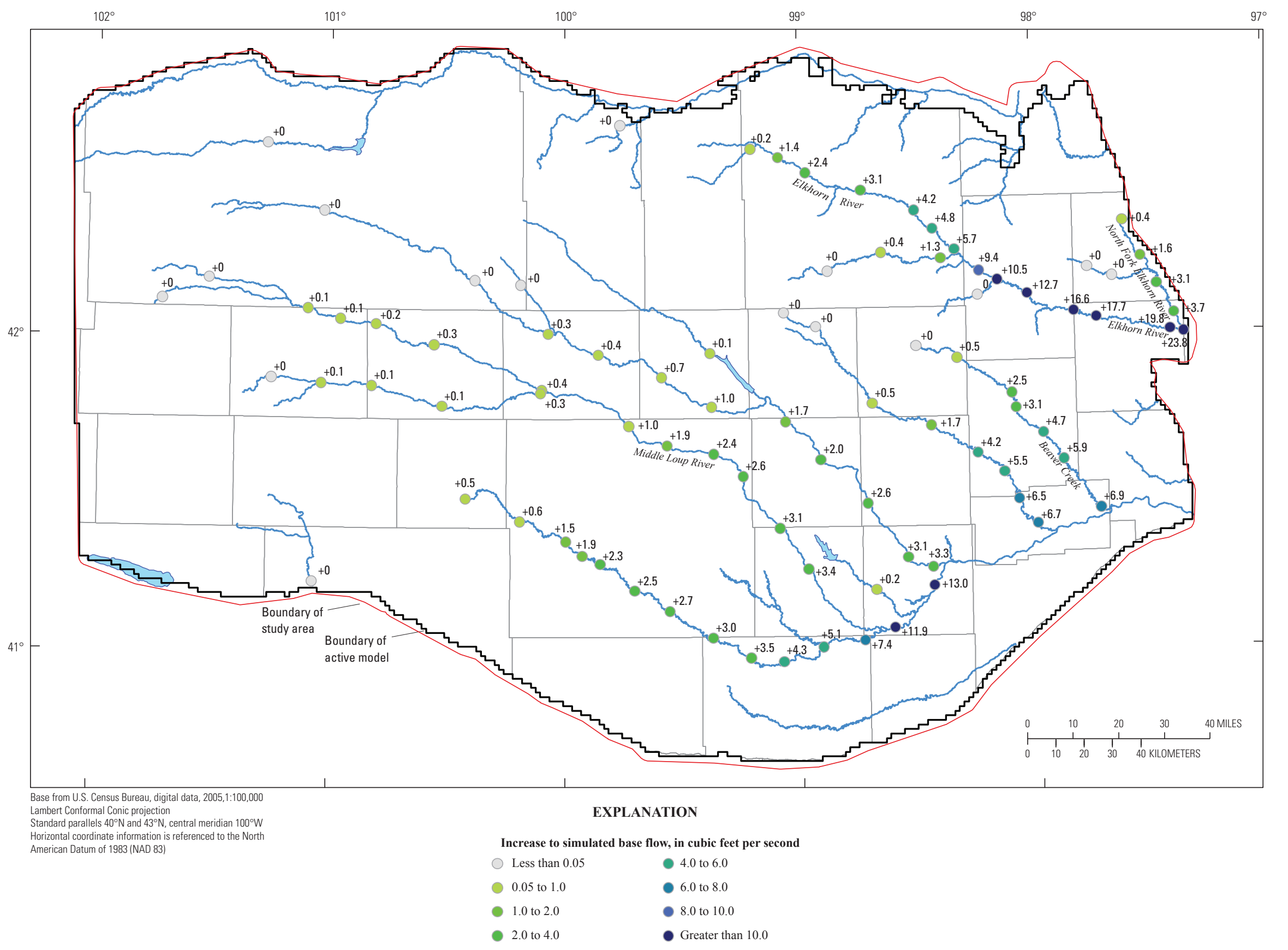

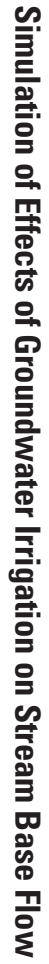

Figure 32. Increase to simulated 2033 base flow caused by 10 percent reduction in irrigated acres within Lower Elkhorn, Lower Loup, Upper Elkhorn, and Upper Loup Natural Resources Districts, 2009 through 2033 simulation period. 


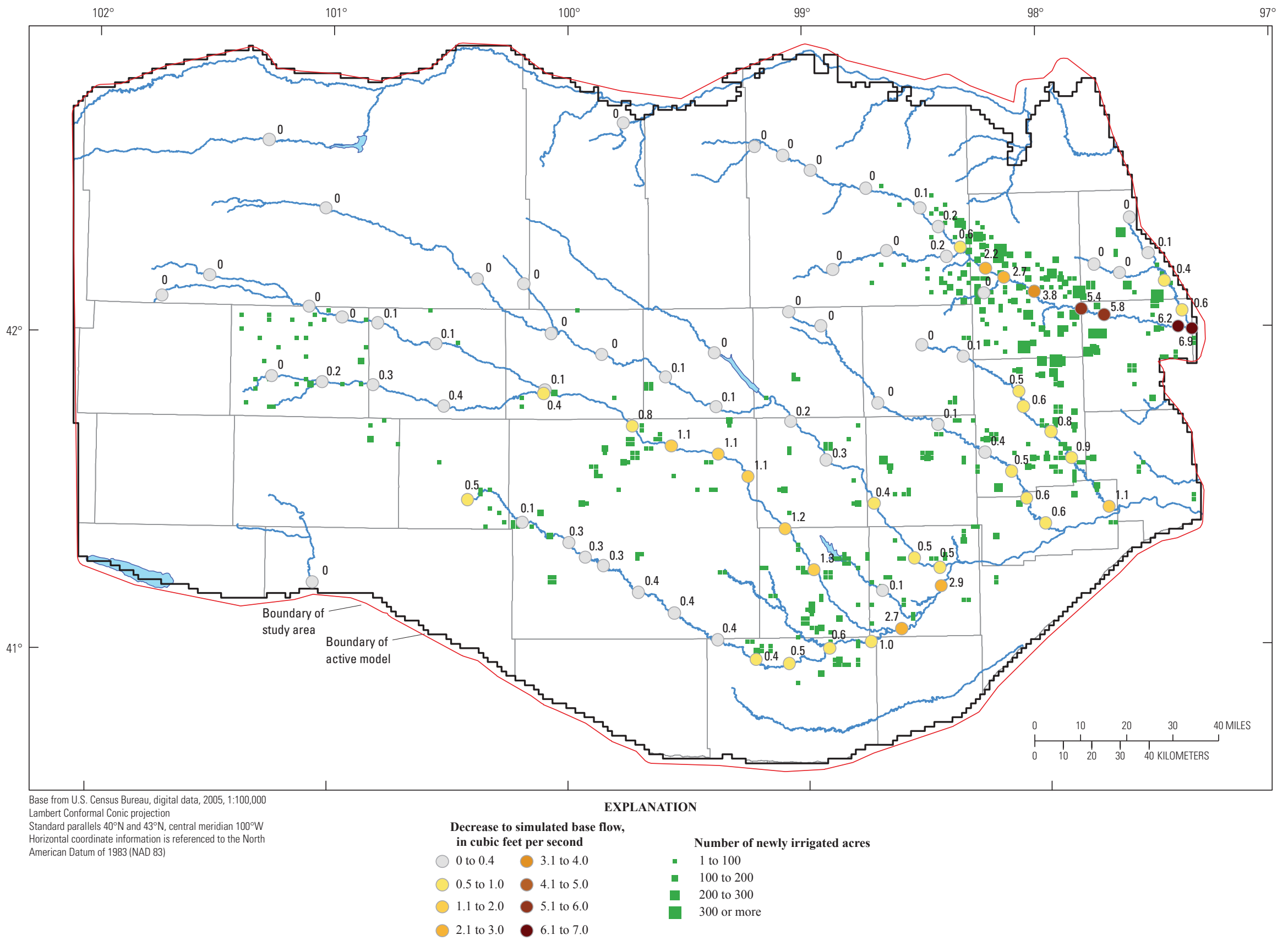

Figure 33. Decrease to simulated 2033 base flow caused by 25,000-acre increase in irrigated acres within Lower Elkhorn, Lower Loup, Lower Platte North, Upper Elkhorn, and Upper Loup Natural Resources Districts, 2009 through 2033 simulation period. 


\section{Optimal Groundwater Pumpage}

Optimization modeling coupled with a groundwaterflow simulation can be used to determine the allocation of scarce resources (Ahlfeld and others, 2005, 2009; Barlow, 2005). A simulation-optimization model has the capacity to integrate management goals (such as maintaining base flow or minimizing groundwater-level declines) and management constraints (such as maximum and minimum pumping rates) into a groundwater-flow simulation. A simulation-optimization model can identify an optimal management strategy for meeting the management goals within imposed constraints. Previous applications of simulation-optimization models for specific groundwater-management scenarios have been described in detail by Danskin and others (2005) and Barlow and Dickerman (2001).

\section{Simulation-Optimization Model}

Simulated base flow of the Elkhorn River at Norfolk (USGS site 06799000) was $263.3 \mathrm{ft}^{3} / \mathrm{s}$ at the end of the simulation-calibration period (2005) (figs. 22 and 34; table 7).
With no reduction to simulated pumpage (baseline condition), base flow in the Elkhorn River at Norfolk is predicted to decline more than 50 percent (to $124.4 \mathrm{ft}^{3} / \mathrm{s}$ ) by 2033 (fig. 34, table 7). Simulated base-flow declines are a product of the assumptions that were used to predict future land use and climatic conditions within the study area, as well as the delayed effects of simulated recharge and pumpage before 2006. One key assumption is that future recharge from precipitation will be equal to the average recharge from precipitation during 1940 through 2005 . That average value was assigned to the simulation for 2006 through 2055, and represents an 18-percent reduction of total recharge within the Elkhorn River Basin (defined by the approximate surface-water drainage basin) from the average recharge simulated during 1980 through 2005 (the time period associated with increasing development of irrigated agriculture) (fig. 34). Simulated pumpage for 2006 through 2055 in the Elkhorn River Basin is slightly larger than simulated pumpage in 2005 (fig. 34), because additional irrigation wells were registered in the study area from 2006 through 2008 and the basin-average effective precipitation used for the Elkhorn River Basin for the 2009 through 2055 period (16.4 in/yr) was slightly less than the average effective

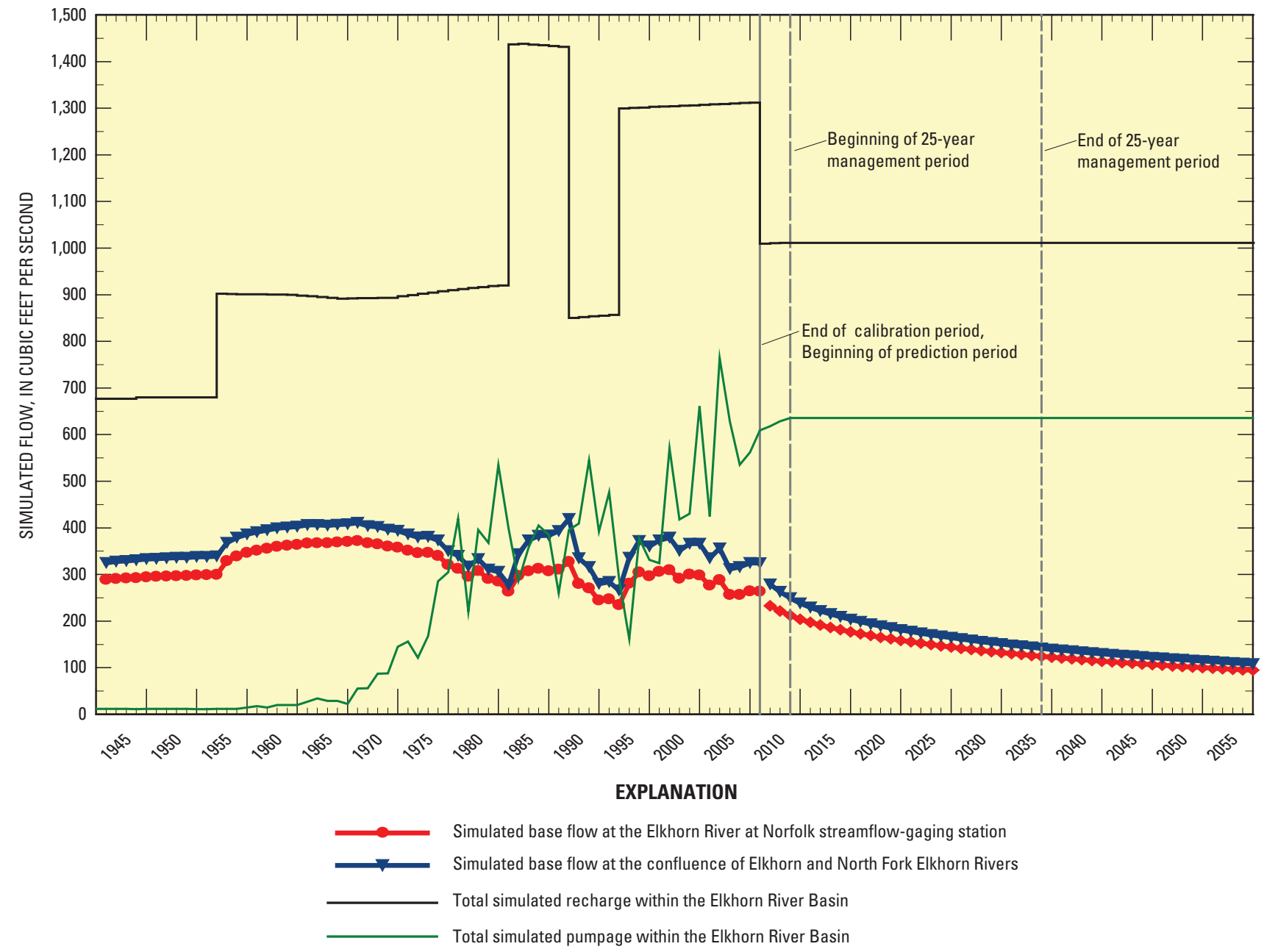

Figure 34. Simulated annual base flow, recharge, and pumpage within the Elkhorn River Basin, 1940 through 2055. 
precipitation calculated for 2005 (17.1 in/yr). These assumptions about future conditions - decreased future recharge and slightly increased pumping - caused simulated base flow within the Elkhorn River Basin to decline. If alternate assumptions were substituted, future simulated base flow would likely be different.

Water-resources managers typically are interested in managing pumpage to limit declines in base flow. Therefore, a simulation-optimization model was developed to predict the minimum reduction of groundwater pumpage within the Upper and Lower Elkhorn NRDs that would be necessary for the next 25 years (from 2009 through 2033) in the Elkhorn River Basin to maintain hypothetical base-flow requirements in the Elkhorn River as simulated in 2033. A description of the hypothetical base-flow requirements is discussed below.

Two management areas were defined for the scenarios: the Upper Elkhorn NRD and the Lower Elkhorn NRD (fig. 35). The simulation-optimization model was formulated to adjust pumpage within those two management areas independently for the 2009 through 2033 period, so that the sum of simulated pumpage reductions from both NRDs was minimized. Pumpage for those years was defined for each well in the scenario as a static rate that did not change with time. Pumpage rates for 2006 through 2008 were the rates used in the baseline simulation. In the simulation-optimization model, pumpage was constrained neither to decrease by more than one-half of the net irrigation pumpage nor to exceed the net irrigation pumpage values used during the baseline simulation. These constraints may not be a realistic representation of future pumpage in the Elkhorn River Basin. For example, water-management agencies may be unwilling or unable to require pumpage reductions approaching 50 percent. Also, additional wells have already been installed since 2008 (Nebraska Department of Natural Resources, 2010). However, these constraints serve as a starting place for assessing the relation between changes in pumpage and future base flows. During the 2009 through 2033 period in the baseline simulation, total annual groundwater withdrawals for irrigation from the Upper Elkhorn NRD were 389,000 acre-ft/yr, and corresponding total annual withdrawals from the Lower Elkhorn NRD were 146,000 acre-ft/yr.

The simulated pumpage rate at each existing, managed well was proportional to the amount pumped at that well in 2009 during the baseline simulation. Pumpage at all existing wells within each of the two NRDs was reduced by a uniform percentage, but pumpage within the Upper Elkhorn NRD was allowed to decrease by a different percentage than used for the Lower Elkhorn NRD. Simulated pumpage at wells outside of the Upper and Lower Elkhorn NRDs was set equal to the pumpage used in the baseline simulation (fig. 35).

Accurate response of base flow to pumpage rates in a simulation-optimization model is dependent upon simulation linearity. A groundwater-flow simulation can be nonlinear when the simulated aquifer is unconfined or when groundwater discharge is dependent upon simulated groundwater levels, such as discharges for ET and to streams. Therefore, management scenarios were solved using a sequential linear programming (SLP) approach described by Ahlfeld and others (2009). The simulation was only weakly nonlinear, as indicated by the ability of the simulation to solve in two iterations with a closure criterion of 1 percent. Nevertheless, SLP was used because the groundwater-flow simulation contained some features that might cause non-linearity. With this approach, the nonlinear features within the simulation were repeatedly linearized by recalculating the response of base flow to small changes in pumpage values (Ahlfeld and others, 2009). The result was a formulation that closely approximates a linear system.

The principal management constraint imposed for the optimization simulations was the minimum base-flow requirement in 2033. Because no definite minimum requirement was established, multiple settings of the constraint were tested in a series of optimization simulations. These multiple-potentialminimum-required base-flow rates are herein termed "hypothetical base-flow requirements." The goal of each simulation in the series was to find the minimal reduction to groundwater pumpage in each NRD that would maintain a specified amount of hypothetically required base flow. Hypothetical base-flow requirements were defined as a percentage of 2005 simulated base flow. Results from the series of optimization simulations were expected to provide water-resources managers with potential management solutions for a wide range of hypothetical base-flow requirement goals, enabling an understanding of the tradeoff between maintaining base flows and maximizing pumpage and agricultural productivity.

Initially, minimal base-flow requirements were defined only for the Elkhorn River at Norfolk (station 06799000), and effects to base flows downstream from that streamgage were not considered. However, the distribution of pumping wells (fig. 35) indicated that many of the wells north of the Elkhorn River and west of the North Fork Elkhorn River would have an effect on future base flow of the North Fork Elkhorn River. Because the Elkhorn River at Norfolk streamgage is upstream from the confluence of the North Fork Elkhorn and Elkhorn Rivers, the effect of simulated pumpage at many of the wells in the Lower Elkhorn NRD may not be evident if simulations only specified a base-flow requirement for the Elkhorn River at Norfolk streamflow-gaging station. For these reasons, a second simulation-optimization scenario was developed that imposed minimum base-flow requirements at the Elkhorn River at Norfolk streamflow-gaging station and the confluence of the Elkhorn River and the North Fork Elkhorn River. A third scenario was developed to estimate optimal minimum reductions in pumpage that would maintain enough base flow at the Elkhorn River at Norfolk streamflow-gaging station and the confluence of the Elkhorn River and the North Fork Elkhorn River to satisfy, in part, a specific downstream water right. 


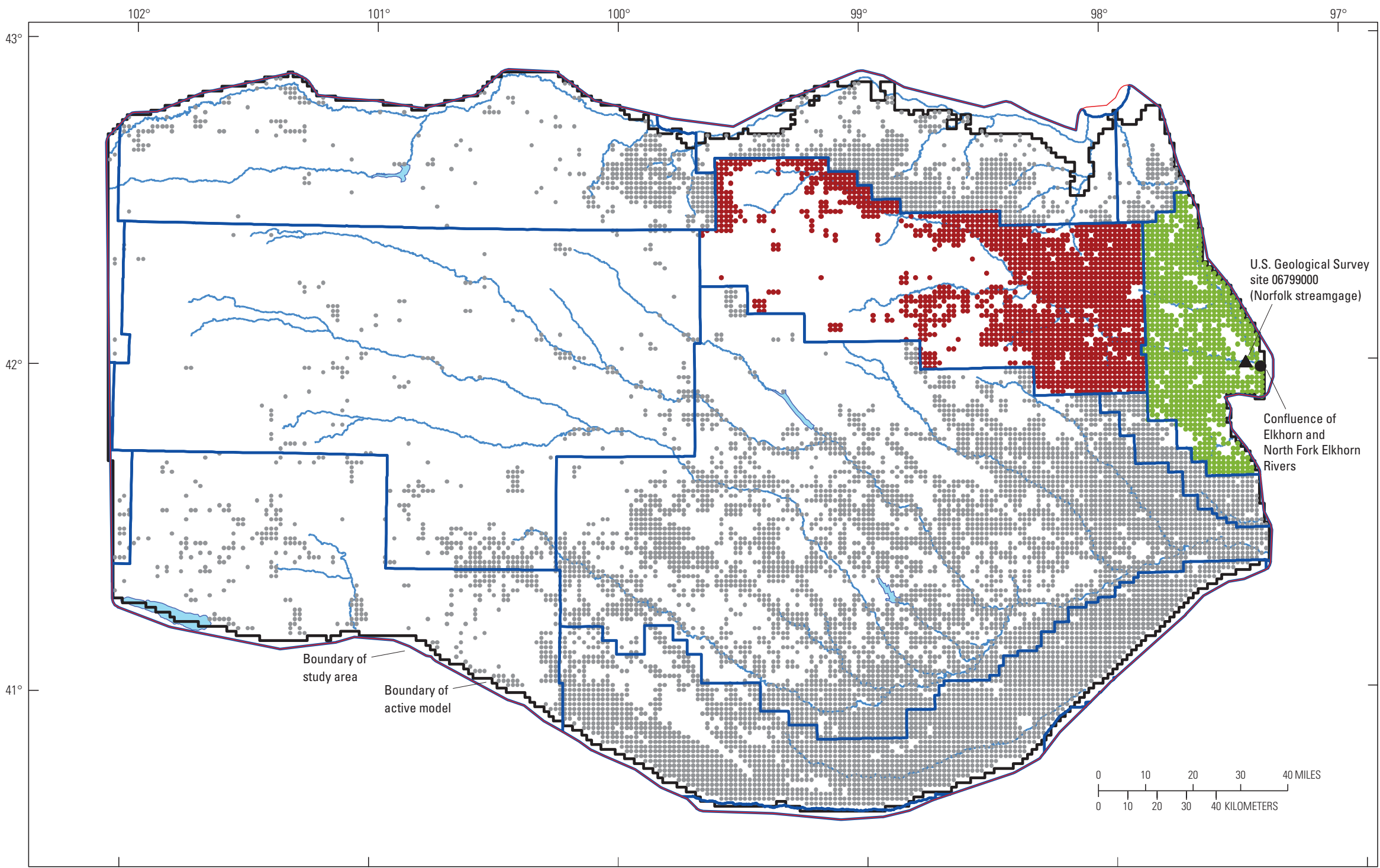

Base from U.S. Census Bureau, digital data, 2005, 1:100,000

Horizontal coordina 40 Nand $43^{\circ} \mathrm{N}$, central meridian $100^{\circ} \mathrm{W}$ (a)

- Natural Resources District boundary

- Managed well within the Upper Elkhorn Natural Resources Distric

Managed well within the Lower Elkhorn Natural Resources District

Unmanaged well (pumpage not adjusted during simulation-optimization model scenarios)

Figure 35. Management status of pumping wells included in simulation-optimization model, 2009 through 2033, Elkhorn and Loup River Basins, Nebraska. 


\section{Results of the Simulation-Optimization Model}

\section{Scenario 1: Base-Flow Requirement Specified for Elkhorn River at Norfolk}

The simulation-optimization model was used to evaluate the relation between pumpage and base flow in the Elkhorn River at Norfolk. The optimal reduction in pumpage necessary to meet a series of hypothetical, minimum base-flow requirements in 2033 is shown in figure 36. Decreases in pumpage are given as a percentage reduction from 2009 baseline simulated pumpage values. Minimum base-flow requirements are shown as a percentage of simulated base flow at the end of the calibration period (2005). With no reduction in pumpage from 2009 through 2033, simulated base flow is predicted to be 47 percent of 2005 simulated base flow (53 percent reduction). When minimum base-flow requirements greater than 47 percent of 2005 were specified, the optimal pumpage results indicate that groundwater withdrawals within the Upper Elkhorn NRD have a larger effect on simulated base flow at the Elkhorn River at Norfolk streamgage than does pumpage within the Lower Elkhorn NRD. If base-flow requirements only are defined for the Elkhorn River at Norfolk streamgage, minimal reduction in overall pumpage within both NRDs was achieved if pumpage was reduced in the Upper Elkhorn NRD and pumpage was held constant at the baseline simulated values (no pumpage reduction) in the Lower Elkhorn NRD. Once pumpage within the Upper Elkhorn NRD was reduced by 50 percent (the maximum reduction to pumpage allowed for this scenario), pumpage then was reduced in the Lower Elkhorn NRD to maintain base flow at the Elkhorn River at Norfolk streamgage. To maintain simulated base flow at 90 percent of the simulated 2005 base flow, pumpage is optimally reduced within the Upper Elkhorn NRD by 50 percent and within the Lower Elkhorn NRD by 41 percent. It was not possible in this scenario to maintain base flow at 91 percent of the 2005 simulated base flow unless pumpage was reduced by more than 50 percent.

\section{Scenario 2: Base-Flow Requirement Specified for Elkhorn River at Norfolk and at Confluence with North Fork Elkhorn River}

In the second simulation-optimization scenario, simulated base flow at the confluence of the North Fork Elkhorn and Elkhorn Rivers (fig. 35) also was considered as a management constraint. Minimum reduction to total simulated pumpage was determined while simultaneously maintaining

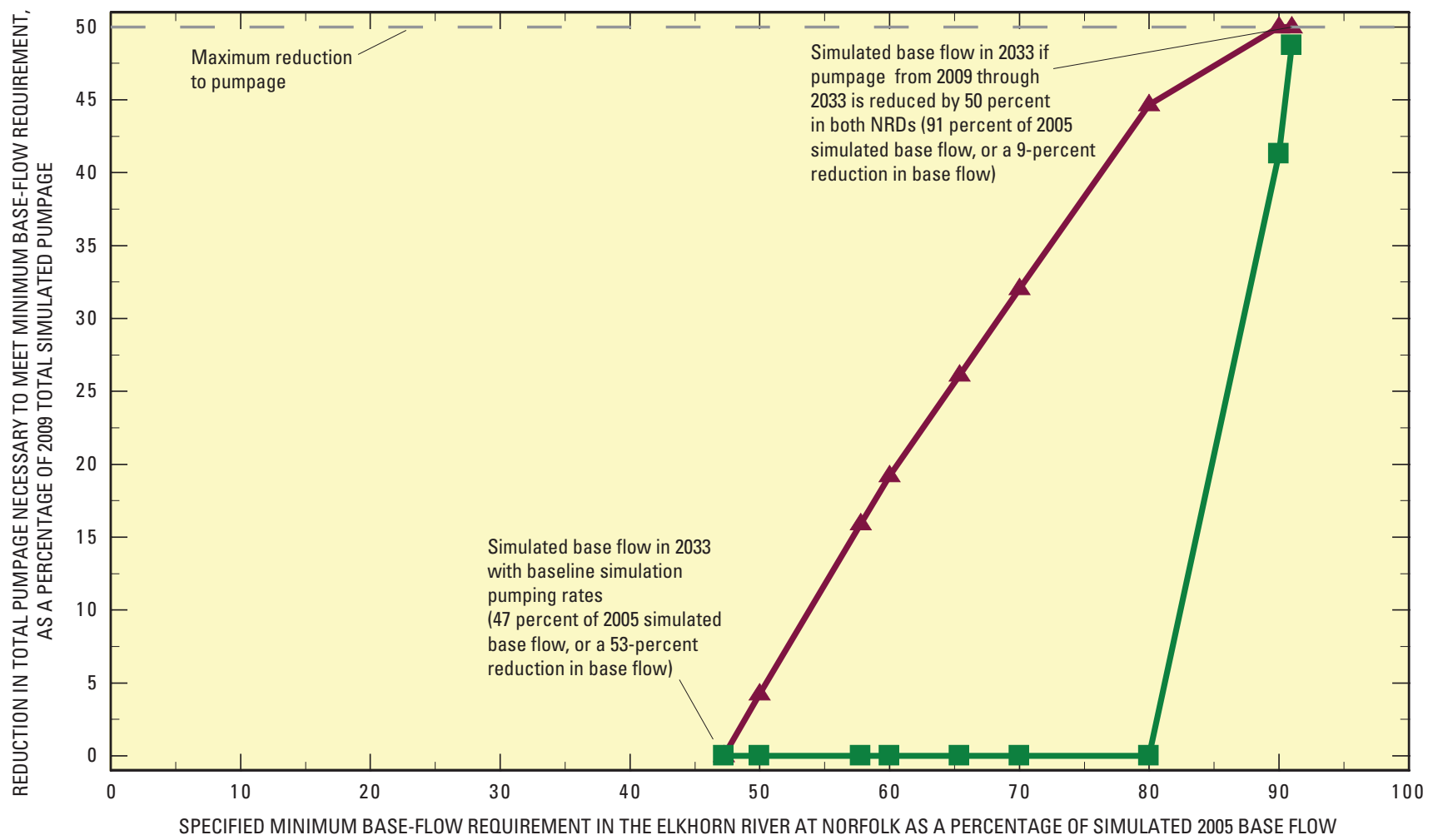

EXPLANATION

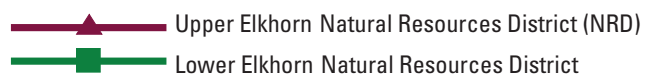

Figure 36. Optimal reduction in simulated pumpage necessary to meet hypothetical base-flow requirements in 2033 for Elkhorn River at Norfolk, Nebraska. 
simulated base flow for the Elkhorn River at Norfolk streamgage and the confluence of the two rivers at various percentages of simulated 2005 base flow (fig. 37). As in figure 36 , each of the base-flow requirements plotted in figure 37 represents a hypothetical management requirement that could be chosen by water-resources managers. During the baseline simulation (no reduction to pumpage), base flow at the confluence of the two rivers was predicted to decline from $324 \mathrm{ft}^{3} / \mathrm{s}$ in 2005 to $142 \mathrm{ft}^{3} / \mathrm{s}$ in 2033 (44 percent of 2005 base flow). Once minimum simulated base-flow requirements greater than 44 percent of 2005 flows were specified, minimal reduction to pumpage was achieved when pumpage was initially reduced only within the Lower Elkhorn NRD. Simulated pumpage within the Lower Elkhorn NRD was reduced by more than 25 percent before pumpage reductions within the Upper Elkhorn NRD were part of the optimized solution to maintain simulated 2033 base flow at rates greater than 50 percent of 2005 base flow. It was not possible to maintain simulated base flow at both sites at more than 86 percent of the 2005 simulated base flows unless pumpage was reduced by more than 50 percent.

Simulation-optimization results indicated that the simulated base-flow requirement at the confluence of the Elkhorn and North Fork Elkhorn Rivers ultimately determined the predicted minimum reduction to total pumpage necessary to satisfy both minimum base-flow requirements. In other words, if minimum base-flow requirements are specified only for the Elkhorn River at Norfolk, simulated pumpage does not need to be reduced as much to satisfy those requirements as it would if minimum base-flow requirements also are specified at the confluence with the North Fork Elkhorn River, according to the optimized solutions.

\section{Scenario 3: Optimal Pumpage for Supporting In-Stream Flow Appropriation A-17331}

The simulation-optimization model also was used to estimate optimal minimum reductions in pumpage that would maintain enough base flow to satisfy, in part, a specific downstream water right. In-Stream Flow Appropriation A-17331 (Nebraska Department of Natural Resources, 1998) is a water right owned by Nebraska Game and Parks Commission that requires at least 3,100 to $3,700 \mathrm{ft}^{3} / \mathrm{s}$ of streamflow to be maintained in the Platte River between the confluence with the Elkhorn River and the mouth of the Platte River (fig. 1) to protect habitat for fish and wildlife. Because the in-stream

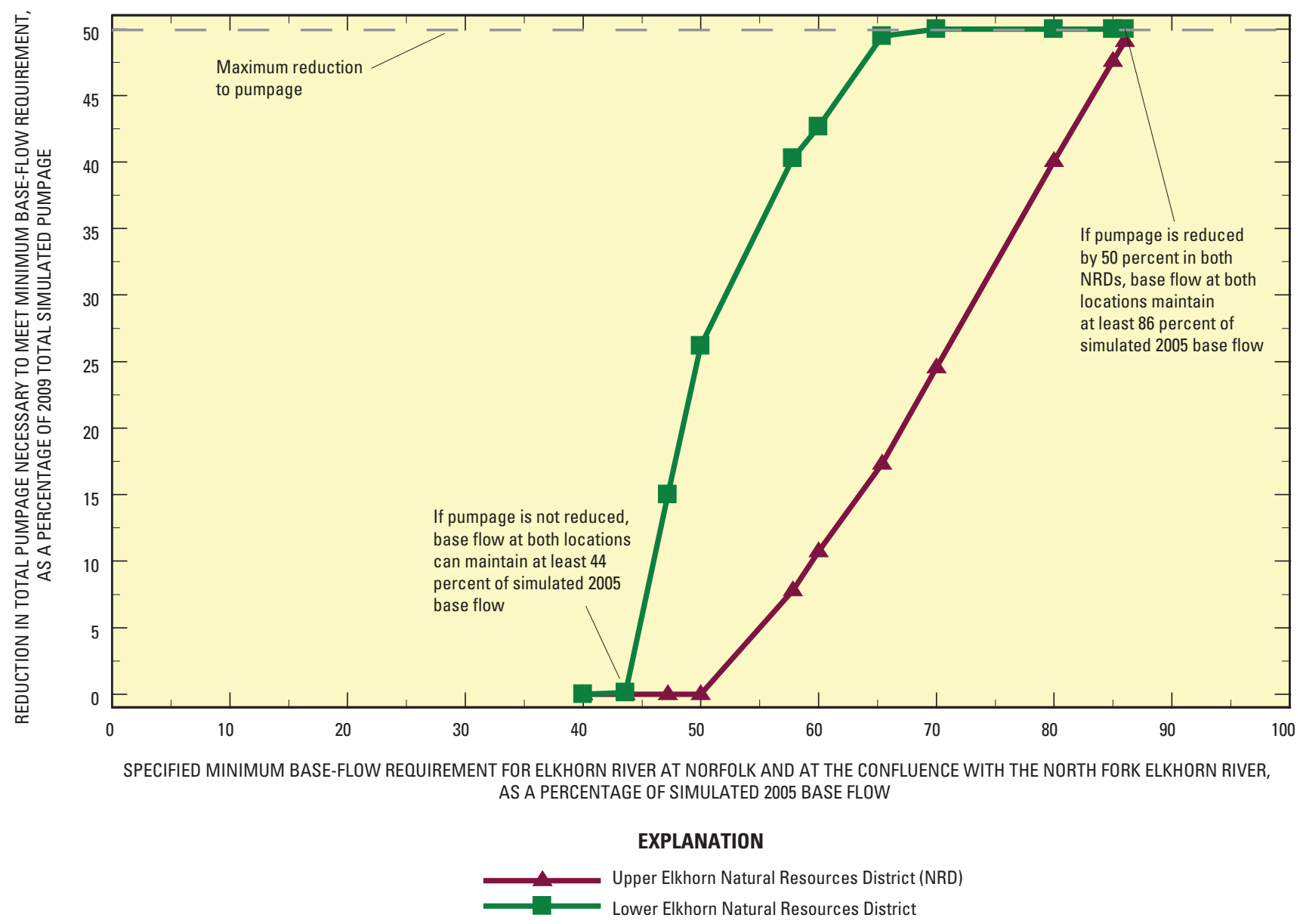

Figure 37. Optimal reduction in simulated pumpage necessary to meet hypothetical base-flow requirements in 2033 for Elkhorn River at Norfolk and at the confluence with North Fork Elkhorn River, Nebraska. 
flow appropriation is specified for a location downstream from the edge of the study area, estimations were for the proportion of the appropriated streamflow that might be expected to originate from streamflow within the ELM study area. In addition, groundwater-flow simulations are only able to simulate the component of streamflow derived from groundwater discharge to streams; therefore, it was necessary to estimate the proportion of the streamflow requirement that, on average, is contributed by base flow. The simulation-optimization model was used to predict the maximum pumpage that can be sustained in the Lower and Upper Elkhorn NRDs while maintaining sufficient base flow in the Elkhorn River at Norfolk and at the confluence with the North Fork Elkhorn River to meet the estimated study-area share to satisfy Appropriation A-17331.

\section{Estimating Base-Flow Requirement for Appropriation A-17331}

Before calculating the base-flow requirement needed to satisfy Appropriation A-17331, the ratios of annual mean streamflow in the Elkhorn River at Norfolk to annual mean streamflow in the Platte River at Louisville were examined to assess the variability from year to year. These calculations indicated that annual mean streamflow in the Elkhorn River at Norfolk composed between 5.0 and 13.3 percent of the annual streamflow in the Platte River at Louisville (U.S. Geological Survey, 2008). The average of all years (1954 through 2007) was 7.4 percent, and the median was 7.1 percent. Because the range of this ratio was small, it was deemed a meaningful relation to guide apportioning of the needed minimum instream flow among its several contributing sources, including the source of interest - streamflow of the Elkhorn River at Norfolk. A similar analysis of the annual ratio between streamflows in the Loup River at Columbus (the most downstream streamgage along the Loup River within the study area) and the Platte River at North Bend (corresponding to In-Stream Flow Appropriation A-17330) indicated that the ratio of Loup River streamflow at Columbus to streamflow at North Bend ranged from 10.6 to 32.1 percent. This range in streamflow ratio was deemed too large to indicate a meaningful guide to apportion needed streamflow among sources; therefore, the simulation-optimization models did not include the Loup Basin as part of this formulated scenario.

Estimates of base flow required in Elkhorn River at Norfolk to satisfy the in-stream flow criteria were calculated using two methods. The goal of the first method was to estimate the amount of base flow that would be needed in Elkhorn River at Norfolk to maintain the average historical frequency at which streamflow met or exceeded the larger in-stream flow criterion $\left(3,700 \mathrm{ft}^{3} / \mathrm{s}\right)$. According to Dietsch and others (2009), daily mean streamflow in the Platte River at Louisville equaled or exceeded 3,700 ft $3 / \mathrm{s} 69.4$ percent of the time for the period of record (1953-2004). If that percentage is applied to Elkhorn River at Norfolk, the amount of streamflow that was met or exceeded 69.4 percent of the time over the period of record was $242 \mathrm{ft}^{3} / \mathrm{s}$. The base-flow part of that streamflow rate was estimated by multiplying $242 \mathrm{ft}^{3} / \mathrm{s}$ by 0.63 , the average base-flow index number for the period of record (table 2), to obtain the estimated share of required base flow, $152 \mathrm{ft}^{3} / \mathrm{s}$. This rate of base flow is 58.0 percent of the simulated 2005 base flow.

The goal of the second method was to estimate the amount of base flow that would be needed in the Elkhorn River at Norfolk to meet its share of the in-stream flow criterion every year (assuming average conditions). The average ratio of annual mean streamflow in the Elkhorn River at Norfolk to annual mean streamflow in the Platte River at Louisville (0.074) was assumed to apply to the amount of Elkhorn River streamflow required to satisfy the larger in-stream flow criteria $\left(3,700 \mathrm{ft}^{3} / \mathrm{s}\right)$. Using this method, the streamflow needed in the Elkhorn River at Norfolk was $274 \mathrm{ft}^{3} / \mathrm{s}$. This amount was then converted to base flow $\left(172 \mathrm{ft}^{3} / \mathrm{s}\right)$ using the average base-flow index for the Elkhorn River at Norfolk. This base-flow rate is about 65 percent of the simulated 2005 base flow.

The applicability of the simulation-optimization results depend upon the validity of the relation of streamflow in the Elkhorn River at Norfolk to streamflow in the Platte River at Louisville as well as the estimates of the base-flow fraction of total Elkhorn River streamflow. Alternate simulated baseline pumpage and climatic conditions would cause different simulation-optimization results (specific optimal pumpage reductions) but the relation between simulated pumpage and base flow is still valid (maintained rate of base flow is still related to total pumpage).

\section{Optimal Pumpage for Supporting Appropriation A-17331}

The methods for solving the third scenario were applied using simulation-optimization models. First, the simulationoptimization model was formulated to maximize pumpage while maintaining sufficient base flow in the ELM study area (58 percent of the 2005 simulated base flow at the Elkhorn River at Norfolk streamgage and the confluence with the North Fork Elkhorn River) to continue preserving the historical frequency (about 70 percent) at which streamflow equaled or exceeded the in-stream flow criterion. Resulting predictions indicated that maximum overall pumpage is achieved when simulated pumpage within the Lower Elkhorn NRD is reduced by about 40 percent and pumpage within the Upper Elkhorn NRD is reduced by about 8 percent.

Next, the simulation-optimization model was formulated to maximize pumpage while maintaining sufficient base flow in the ELM study area to satisfy the in-stream flow criterion every year (65 percent of the 2005 simulated base flow, assuming average conditions). Maximum overall pumpage was predicted to be attained when simulated pumpage within the Lower Elkhorn NRD is reduced by about 49 percent and pumpage within the Upper Elkhorn NRD is reduced by about 17 percent. 


\section{Potential Improvements}

Simulations and analyses reported herein can be enhanced in two important ways to improve simulation accuracy and predicted effects of groundwater irrigation.

- Enhanced data.-For simulations to be as realistic as possible and provide the most utility to water-resources managers, simulation parameters could incorporate new or refined data and more hydrogeologically advanced or computationally superior modeling methods to overcome the limitations discussed in this report. One limitation of the phase-two simulation is an imbalance between simulated recharge and pumpage in some areas where a large percentage of land is used for growing irrigated crops. In several areas, simulated groundwater-level declines were larger than measured groundwater-level declines, indicating that either too much pumpage or too little recharge had been simulated. Additionally, simulated base-flow trends for several streams were downward while estimated base flows increased slightly during the period having the most irrigated-land development (1970 through 2005). Future enhancements to the simulation also could include improved estimates of both the calibrated and directly assigned simulation parameters: refined net irrigation pumpage values, a more detailed accounting of water flow and storage in canals and reservoirs, improved estimates of spatial variability in canal seepage using canal construction information such as lining materials, and further refinement of the estimation of recharge from precipitation. Characterization of aquifer properties can be improved using additional test-hole and surface- and borehole-geophysics data.

- Enhanced discretization.-Additional vertical layers representing changes to aquifer properties with depth could be incorporated into the model formulation. Seasonal crop and water-management differences could be evaluated if shorter stress periods were selected during temporal discretization and if seasonal changes to ET, pumpage, and recharge were characterized.

\section{Summary and Conclusions}

A cooperative study was designed by the U.S. Geological Survey, Lower Loup Natural Resources District (NRD), Upper Elkhorn NRD, Lower Elkhorn NRD, Lower Platte North NRD, Middle Niobrara NRD, Nebraska Department of Natural Resources, and the Conservation and Survey Division, University of Nebraska-Lincoln to improve understanding of the stream-aquifer interactions and quantify the effects of groundwater irrigation on base flow within Nebraska's Elkhorn and Loup River Basins. The phase-two groundwater-flow simulations documented in this report incorporate updates based on newly collected data and supporting analyses performed in 2007 and 2008. Other enhancements to the simulations include improved calibration methods, smaller grid cells, time-variant rates of recharge from precipitation, time-variant base-flow estimates used as calibration targets, improved estimates of groundwater withdrawals for irrigation, and refined delineation of active evapotranspiration grid cells. This report describes the refinement of the phase-one regionalscale groundwater-flow simulations and predicted effects of groundwater irrigation on stream base flow in the Elkhorn and Loup River Basins. This report describes the construction and calibration of the simulations, and methods used to predict changes to stream base flow as a result of simulated changes to groundwater irrigation.

A groundwater-flow simulation was constructed and calibrated for the study area, using a 1-mile cell spacing horizontally and a single layer vertically. The active simulation domain included a 29,707-square mile area of north-central Nebraska. A simulation for the predevelopment through 2005 period was calibrated by adjusting selected parameters until simulated groundwater levels (1939), decadal groundwaterlevel changes (1945-2005), and base flows (pre-1940 through 2005 ) best reproduced measured or estimated values. Calibration proceeded in two stages. In the first stage, manual trialand-error calibration techniques were used. The second stage of calibration used automated calibration techniques.

The calibration results of the pre-1940 period indicated that 81 percent of the simulated groundwater levels were within $30 \mathrm{ft}$ of the measured groundwater levels. The results did not determine large areas of simulated groundwater levels that were biased too high or too low, indicating that the simulation generally captures the regional trends. Calibration results using 1945 through 2005 decadal groundwater-level changes indicated that a majority of the simulated groundwater-level changes were within 5 feet of the changes calculated from measured groundwater levels. Simulated groundwaterlevel rises generally were smaller than measured rises near surface-water irrigation districts. Simulated groundwater-level declines were larger than measured declines in several parts of the study area having large amounts of irrigated crops. Baseflow trends and volumes generally were reproduced by the simulation at most sites. Exceptions include downward trends of simulated base flow from the 1970s to the end of the calibration period for the Elkhorn River at Norfolk, Beaver Creek at Genoa, and Cedar River near Fullerton.

The calibrated simulation was used to project future base flows without any changes to groundwater irrigated acres after 2008. Most streams had less simulated base flow in 2055 than in 2005. Streamflow-gaging stations along the Elkhorn River had the largest reduction to simulated base flow. The Elkhorn River at Norfolk streamflow-gaging station had about 170 cubic feet per second (or 64 percent) less simulated base flow in 2055 than in 2005. Downstream streamflowgaging stations on the Cedar River and Beaver Creek had about 40 cubic feet per second less base flow in 2055 than in 2005 , reductions of 24 and 93 percent, respectively. Several 
streamflow-gaging stations along the North Loup River had more simulated base flow in 2055 than in 2005.

Effects of groundwater irrigation on stream base flow were predicted using several methods: (1) simulated base-flow depletion was mapped to represent the percentage of water pumped from a hypothetical well during 2006 through 2055 that corresponds to base-flow depletions at the end of that 50 -year period, (2) the groundwater-flow simulation predicted changes in stream base flow that result from changes to the number of irrigated acres over a 25-year period (2009 through 2033), and (3) a simulation-optimization model determined the minimum reduction of groundwater pumpage within the Upper and Lower Elkhorn NRDs that would be necessary in the Elkhorn River Basin during 2009 through 2033 to maintain various levels of base flow in the Elkhorn River.

Simulated base-flow depletion results, mapped at the end of a 50-year simulation run, indicate that depletions of less than 10 percent of pumpage in 50 years occur mainly in areas that are about 10 miles or farther from the Elkhorn and Loup Rivers and their tributaries.

Future changes to base flow predicted to result from changes to the number of irrigated acres were simulated for a 25-year period (2009 through 2033). The effects of changing irrigated acres include the effect of changing the amount of groundwater pumpage as well as the amount of additional recharge originating from irrigated cropland. When the calibrated simulation was used to predict how base flow would be affected by a 10-percent decrease in irrigated acres after a 25 -year period, the largest increases to base flow were simulated at downstream locations, demonstrating the cumulative effects of reductions in irrigated acres. In addition, the number of irrigated acres generally is larger in the southern and eastern parts of the study area, coinciding with downstream locations. Simulated base flow was predicted to increase by a maximum of 13.0 cubic feet per second in the Loup River Basin and by as much as 23.8 cubic feet per second in the Elkhorn River Basin. The largest percentage increases in simulated base flow relative to the simulated baseline base flow occurred along Beaver Creek, the North Fork Elkhorn River, and the Elkhorn River.

The calibrated simulation was used to predict how base flow would be affected after a 25 -year period by an increase of as much as 2,500 acres per year for 4 years in each of the Lower Elkhorn, Lower Loup, Lower Platte North, Upper Elkhorn, and Upper Loup NRDs (a total increase of about 25,000 irrigated acres across the study area). Simulated base flow was predicted to decrease by a maximum 2.9 cubic feet per second in the Loup River Basin and by as much as 6.9 cubic feet per second in the Elkhorn River Basin. Changes to base flow were related to the proximity of the hypothetical newly irrigated acres to a stream.

A simulation-optimization model was formulated to minimize reductions in pumpage while maintaining base flows in two key reaches of the Elkhorn River at 58 percent of 2005 simulated base flow. This base-flow target corresponds to the estimated base-flow rate needed to support an in-stream flow criterion for the Platte River (A-17331 criterion) for 70 percent of the time. Maximum overall pumpage was optimized when simulated pumpage within the Lower Elkhorn NRD was reduced by about 40 percent and pumpage within the Upper Elkhorn NRD was reduced by about 8 percent. When the simulation-optimization model was formulated to maximize pumpage while maintaining base flows in the two key reaches of the Elkhorn River at 65 percent of 2005 simulated base flow (a more conservative estimate of the base-flow rate needed to support the in-stream flow criteria A-17331), maximum overall pumpage was optimized when simulated pumpage within the Lower Elkhorn NRD was reduced by about 49 percent and pumpage within the Upper Elkhorn NRD was reduced by about 17 percent. Although the two base-flow target rates are not regulatory requirements, the results provide benchmarks for the Natural Resources Districts as they determine appropriate management goals.

The simulations documented in this report have limitations, as do all tools used to analyze the function of complex natural systems. Uncertainties in some simulation inputs were not quantifiable, causing uncertainties in the results of the analyses that used these simulations to also be unquantifiable. However, the simulations documented in this report are as accurate as could reasonably be expected given the inputdata limitations, system simplifications, simulation assumptions, and resources available at the time of the simulation construction and calibration. Development of the regional simulations focused on generalized hydrogeologic characteristics within the study area, and did not attempt to describe variations important to local-scale conditions. For example, a single unconfined layer was used to simulate the aquifer. These regional simulations are most appropriate for analyzing groundwater-management scenarios over large areas and long time periods, and are not reliable for analysis of small areas or short time periods.

\section{References Cited}

Ahlfeld, D.P., Barlow, P.M., and Mulligan, A.E., 2005, GWM-A ground-water management process for the U.S. Geological Survey modular ground-water model (MODFLOW-2000): U.S. Geological Survey Open-File Report 2005-1072, 124 p. (Also available at http://water.usgs.gov/ nrp/gwsoftware/mf2005_gwm/OFR2005_1072.pdf.)

Ahlfeld, D.P., Baker, K.M., and Barlow, P.M., 2009, GWM2005-A groundwater-management process for MODFLOW-2005 with local grid refinement (LGR) capability: U.S. Geological Survey Techniques and Methods, book 6, chap. A33, 65 p. (Also available at http://pubs.usgs.gov/tm/ tm6a33/pdf/tm6-A33_508.pdf.)

Anderson, M.P., and Woessner, W.W., 1992, Applied groundwater modeling - Simulation of flow and advective transport: San Diego, Academic Press, 381 p. 
Barlow, P.M., 2005, Use of simulation-optimization modeling to assess regional ground-water systems: U.S. Geological Survey Fact Sheet 2005-3095, 4 p.

Barlow, P.M., and Dickerman, D.C., 2001, Numerical-simulation and conjunctive-management models of the HuntAnnaquatucket-Pettaquamscutt stream-aquifer system, Rhode Island: U.S. Geological Survey Professional Paper $1636,88 \mathrm{p}$.

Bleed, A.S., and Flowerday, C.A, eds., 1989, An atlas of the Sand Hills ( $3 \mathrm{~d}$ ed.): Conservation and Survey Division, Institute of Agriculture and Natural Resources of the University of Nebraska, Resource Atlas no. 5b, 260 p.

Center for Advanced Land Management Information Technologies, 2007, 2005 Nebraska land use patterns: Lincoln, Nebr., Center for Advanced Land Management Information Technologies, remote-sensing image, scale 1:100,000, accessed October 1, 2007, at http://www.calmit.unl. edu/2005landuse/statewide.shtml.

Condra, G.E., and Reed, E.C., 1943, The geological section of Nebraska: Nebraska Geological Survey Bulletin (Conservation and Survey Division, University of Nebraska-Lincoln), v. 14 , p. 82 .

Conservation and Survey Division, 1996a, Thickness of the principal aquifer: Lincoln, University of Nebraska, Institute of Agriculture and Natural Resources, digital data, file wtthick.e00, accessed July 21, 2005, at http://snr.unl.edu/data/geographygis/NebrGISdata.asp.

Conservation and Survey Division, 1996b, Bedrock geology: Lincoln, University of Nebraska, Institute of Agriculture and Natural Resources, digital data, file bedrock.e00, accessed July 21, 2005, at http://snr.unl.edu/data/geographygis/NebrGISdata.asp.

Conservation and Survey Division, 1996c, Configuration of the water table, 1979: Lincoln, University of Nebraska, Institute of Agriculture and Natural Resources, digital data, file wtable.e00, accessed August 29, 2005, at http://snr.unl.edu/data/geographygis/NebrGISdata.asp.

Conservation and Survey Division, 2003, 1995 water table contours: Lincoln, University of Nebraska, Institute of Agriculture and Natural Resources, digital data, file watertable95.e00, accessed February 28, 2003, at http://snr.unl.edu/data/geographygis/NebrGISdata.asp.

Conservation and Survey Division, 2005a, Transmissivity of the principal aquifer, 2005: Lincoln, University of Nebraska, Institute of Agriculture and Natural Resources, digital data, accessed August 5, 2005, at http://snr.unl.edu/data/geographygis/NebrGISdata.asp.
Conservation and Survey Division, 2005b, Specific yield of the principal aquifer, 2005: Lincoln, University of Nebraska, Institute of Agriculture and Natural Resources, digital data, accessed August 3, 2005, at http://snr.unl.edu/data/geographygis/NebrGISdata.asp.

Conservation and Survey Division, 2005c, Till: Lincoln, University of Nebraska, Institute of Agriculture and Natural Resources, digital data, accessed July 14, 2005, at http://snr.unl.edu/data/geographygis/NebrGISdata.asp.

Danskin, W.R., McPherson, K.R., and Woolfenden, L.R., 2005, Hydrology, description of computer models, and evaluation of selected water-management alternatives in the San Bernardino area, California: U.S. Geological Survey Open-File Report 2005-1278, 178 p., 2 pls.

Dietsch, B.J., Godberson, J.A., and Steele, G.V., 2009, Trends in streamflow characteristics of selected sites in the Elkhorn River, Salt Creek, and lower Platte River basins, eastern Nebraska, 1928-2004, and evaluation of streamflows in relation to instream-flow criteria, 1953-2004: U.S. Geological Survey Scientific Investigations Report 2009-5011, 93 p. (Also available at http://pubs.usgs.gov/sir/2009/5011/.)

Doherty, John, 2003, Ground water model calibration using pilot points and regularization: Ground Water, v. 41, no. 2, p. $170-177$.

Doherty, John, 2008a, PEST, model independent parameter estimation user manual (5th ed.): Brisbane, Australia, Watermark Numerical Computing, accessed October 2, 2008, at http://pesthomepage.org/.

Doherty, John, 2008b, PEST, model independent parameter estimation-Addendum to user manual (5th ed.): Brisbane, Australia, Watermark Numerical Computing, accessed October 2, 2008, at http://pesthomepage.org/.

Draper, N.R., and Smith, Harry, 1966, Applied regression analysis: New York, Wiley-Interscience, 407 p.

Dugan, J.T., and Zelt, R.B., 2000, Simulation and analysis of soil-water conditions in the Great Plains and adjacent areas, central United States, 1951-80: U.S. Geological Survey Water-Supply Paper 2427, 81 p.

Environmental Simulations, Inc., 2009, Groundwater Vistas Version 5: Reinholds, Environmental Simulations, Inc., software release August 24, 2009, accessed August 25, 2009, at http://www.groundwatermodels.com.

Fienen, M.N., Doherty, J.E., Hunt, R.J., and Reeves, H.W., 2010, Using prediction uncertainty analysis to design hydrologic monitoring networks - Example applications from the Great Lakes Water Availability Pilot Project: U.S. Geological Survey Scientific Investigations Report 2010-5159, 44 p. (Also available at http://pubs.usgs.gov/sir/2010/5159/.) 
Fienen, M.N., Muffels, C.T., and Hunt, R.J., 2009, On constraining pilot point calibration with regularization in PEST: Ground Water, v. 47, no. 6, p. 835-844.

Freeze, R.A., and Cherry, J.A., 1979, Groundwater: Englewood Cliffs, N.J., Prentice-Hall, 604 p.

Ginn, T.R., Scheibe, T.D., Haeri, Hanieh, and McClain, C.N., 2007, An expanded survey of groundwater modeling practitioners about how they quantify uncertainty-Which tools they use, why, and why not [abs.]: Geological Society of America Abstracts with Programs, v. 39, no. 6, p.110.

Goeke, J.W., Peckenpaugh, J.M., Cady, R.E., and Dugan, J.T., 1992, Hydrogeology of parts of the Twin Platte and Middle Republican Natural Resources Districts, Nebraska: Lincoln, University of Nebraska, Conservation and Survey Division Nebraska Water Survey Paper 70, 89 p.

Granato, G.E., and Barlow, P.M., 2005, Effects of alternative instream-flow criteria and water-supply demands on ground-water development options in the Big River area, Rhode Island: U.S. Geological Survey Scientific Investigations Report 2004-5301, 110 p.

Harbaugh, A.W., 2005, MODFLOW-2005, the U.S. Geological Survey modular ground-water model-The groundwater flow process: U.S. Geological Survey Techniques and Methods, book 6, chap. A16, variously paged. (Also available at http://pubs.usgs.gov/tm/2005/tm6A16/.)

Helsel, D.R., and Hirsch, R.M., 1992, Statistical methods in water resources: Amsterdam, Elsevier, 522 p.

Hill, M.C. and Tiedeman, C.R., 2007, Effective groundwater model calibration - With analysis of data, sensitivities, predictions, and uncertainty: Hoboken, N.J., Wiley-Interscience, $455 \mathrm{p}$.

Hunt, R.J., Doherty, John, Tonkin, M.J., 2007, Are models too simple? Arguments for increased parameterization: Ground Water, v. 45, no. 3, p. 254-262.

Hutson, S.S., Barber, N.L., Kenny, J.F., Linsey, K.S., Lumia, D.S., and Maupin, M.A., 2004, Estimated use of water in the United States in 2000: U.S. Geological Survey Circular 1268, $46 \mathrm{p}$.

Jenkins, C.T., 1968, Computation of rate and volume of stream depletion by wells: U.S. Geological Survey Techniques of Water-Resources Investigations, book 4, chap. D1, 17 p. (Also available at $h t t p: / / p u b s . u s g s . g o v / t w r i / t w r i 4 d 1 /$.)

Landon, M.K., Rus, D.L., Dietsch, B.J., Johnson, M.R., and Eggemeyer, K.D., 2009, Evapotranspiration rates of riparian forests, Platte River, Nebraska, 2002-06: U.S. Geological Survey Scientific Investigations Report 2008-5228, 65 p.
Mantua, N.J., and Hare, S.R., 2002, The Pacific Decadal Oscillation: Journal of Oceanography, v. 58, no. 1, p. 35-44.

Markstrom, S.L., Niswonger, R.G., Regan, R.S., Prudic, D.E., and Barlow, P.M., 2008, GSFLOW-Coupled ground-water and surface-water flow model based on the integration of the Precipitation-Runoff Modeling System (PRMS) and the Modular Ground-Water Flow Model (MODFLOW-2005): U.S. Geological Survey Techniques and Methods, book 6, chap. D1, 240 p. (Also available at http://pubs.usgs.gov/tm/tm6d1/pdf/tm6d1.pdf.)

McGuire, V.L., and Peterson, S.M., 2008, Base of principal aquifer for the Elkhorn-Loup model area, north-central Nebraska: U.S. Geological Survey Scientific Investigations Map 3042, 1 sheet, scale 1:100,000. (Also available at http://pubs.usgs.gov/sim/3042.)

McMahon, P.B., Dennehy, K.F., Bruce, B.W., Böhlke, J.K., Michel, R.L., Gurdak, J.J., and Hurlbut, D.A., 2006, Storage and transit time of chemicals in thick unsaturated zones under rangeland and irrigated cropland, High Plains, USA: Water Resources Research, v. 42, doi:10.1029/2005WR004417.

National Climatic Data Center, 2009, Climate division precipitation data: Asheville, N.C., National Climate Data Center, accessed March 3, 2009, at http://www.ncdc.noaa.gov/oa/climate/stationlocator.html.

Natural Resources Conservation Service, 1986, Urban hydrology for small watersheds (2d ed.): U.S. Department of Agriculture, Technical Release 55, accessed March 19, 2007, at http://www.wsi.nrcs.usda.gov/products/w2q/H\&H/ Tools_Models/other/TR55.html.

Nebraska Department of Natural Resources in work-share agreement with the U.S. Geological Survey, 1998, 7.5 Digital elevation models-DEM-10 meter-Index for the State of Nebraska: Menlo Park, Calif., U.S. Geological Survey, digital data, accessed January 20, 2010, at http://www.dnr.state.ne.us/databank/dem.html.

Nebraska Department of Natural Resources, 1998, In the matter of applications A-17329 through A-17333, Water Divisions 1-A, 2-A and 2-B; Order: Lincoln, Nebraska Department of Water Resources, accessed January 30, 2005, at http://www.dnr.state.ne.us/legal/decision1.htm.

Nebraska Department of Natural Resources, 2005a, Registered well database: Lincoln, Nebraska Department of Water Resources, accessed September 26, 2005, at http://dnrdata.dnr.ne.gov/wellssql/. 
Nebraska Department of Natural Resources, 2005b, 2006 annual evaluation of availability of hydrologically connected water supplies: Lincoln, Nebraska Department of Water Resources, accessed February 1, 2006, at http://www. dnr.state.ne.us/IWM/AnnualReport/2006_AnnualReport.pdf.

Nebraska Department of Natural Resources, 2006, 2007 annual evaluation of availability of hydrologically connected water supplies: Lincoln, Nebraska Department of Water Resources, accessed February 1, 2007, at http://www.dnr.state.ne.us/IWM/AnnualReport_2007/ AnnualReport2007.pdf.

Nebraska Department of Natural Resources, 2008, Streamflow retrieval: Lincoln, Nebraska Department of Water Resources, accessed July 28, 2008, at http://dnrdata.dnr.ne.gov/streamflow.

Nebraska Department of Natural Resources, 2010, Registered well database: Lincoln, Nebraska Department of Water Resources, accessed February 12, 2010, at http://dnrdata.dnr.ne.gov/wellssql/.

Nebraska State Legislature, 2009, LB483 enacted into law: Lincoln, Nebraska State Legislature, accessed January 26, 2010, at http://nebraskalegislature.gov/FloorDocs/Current/ PDF/Intro/LB483.pdf.

Niswonger, R.G., and Prudic, D.E., 2005, Documentation of the Streamflow-Routing (SFR2) package to include unsaturated flow beneath streams-A modification to SFR1: U.S. Geological Survey Techniques and Methods, book 6, chap. A13, $47 \mathrm{p}$.

Peterson, S.M., Stanton, J.S., Saunders, A.T., and Bradley, J.R., 2008, Simulation of ground-water flow and effects of ground-water irrigation on base flow in the Elkhorn and Loup River Basins, Nebraska: U.S. Geological Survey Scientific Investigations Report 2008-5143, 65 p. (Also available at $h t t p: / / p u b s . u s g s . g o v /$ sir/2008/5143/.)

Peterson, S.M., and Strauch, K.R., 2007, Streamflow measurements in north-central Nebraska, November 2006: U.S. Geological Survey Data Series 332, 29 p.

Reilly, T.E., and Harbaugh, A.W., 2004, Guidelines for evaluating ground-water flow models: U.S. Geological Survey Scientific Investigations Report 2004-5038, 30 p.

Scanlon, B.R., Healy, R.W., and Cook, P.G., 2002, Choosing appropriate techniques for quantifying groundwater recharge: Hydrogeology Journal, v. 10, p. 18-39.
Scanlon, B.R., Reedy, R.C., Stonestrom, D.A., Prudic, D.E., and Dennehy, K.F., 2005, Impact of land use and land cover change on groundwater recharge and quality in the southwestern U.S.: Global Change Biology, v. 11, p. 1,5771,593 .

Schmid, Wolfgang, Hanson, R.T., Maddock, Thomas, III, Leake, S.A., 2006, User guide for the farm process (FMP1) for the U.S. Geological Survey's modular threedimensional finite-difference ground-water flow model, MODFLOW-2000: U.S. Geological Survey Techniques and Methods, book 6, chap. A17, 127 p. (Also available at http://pubs.usgs.gov/tm/2006/tm6A17/.)

Strauch, K.R., and Linard, Joshua, 2009, Streamflow simulations and percolation estimates using the Soil and Water Assessment Tool for selected basins in North-Central Nebraska, 1940-2005: U.S. Geological Survey Scientific Investigations Report 2009-5075, 20 p. (Also available at http://pubs.usgs.gov/sir/2009/5075/.)

Teeple, A.P., Vrabel, Joseph, Kress, W.H., and Cannia, J.C., 2009, Apparent resistivity and estimated interaction potential of surface water and groundwater along selected canals and streams in the Elkhorn-Loup Model study area, north-central Nebraska, 2006-07: U.S. Geological Survey Scientific Investigations Report 2009-5171, 66 p.

Theis, C.V., 1940, The source of water derived from wells: Civil Engineering, v. 10, no. 5, p. 277-280.

U.S. Department of Agriculture, variously dated, Census of agriculture: U.S. Department of Agriculture database, accessed May 8, 2006, at http://www.agcensus.usda.gov/.

U.S. Geological Survey, 2005, USGS ground-water data for Nebraska: U.S. Geological Survey database, accessed August 1, 2005, at http://waterdata.usgs.gov/ne/nwis/gw.

U.S. Geological Survey, 2008, USGS streamflow data for Nebraska: U.S. Geological Survey database, accessed July 30, 2008, at http://waterdata.usgs.gov/ne/nwis/sw.

U.S. Geological Survey, 2009, Comparison of selected methods for estimating groundwater recharge in humid regions: Reston, Va., U.S. Geological Survey query tool, accessed June 30, 2010, at http://water.usgs.gov/ogw/gwrp/methods/compare/.

U.S. Weather Bureau, 1959, Evaporation maps for the United States: U.S. Weather Bureau Technical Paper 37, pl. 2, digital data also available at http://cohyst.dnr.ne.gov/cohyst_preliminarydata.html. 
University of Nebraska, 1990, Evapotranspiration (ET) or crop water use: Lincoln, University of Nebraska, Cooperative Extension, NebGuide G90-992-A, accessed January 9, 2007, at http://www.p2pays.org/ref/20/19769.htm.

University of Nebraska, 2002, Crop water use in western Nebraska: Lincoln, University of Nebraska, Cooperative Extension, NebGuide G1465, accessed January 9, 2007, at http://www.ianrpubs.unl.edu/epublic/pages/publicationD. jsp? publicationId $=248$.
Wahl, K.L., and Wahl, T.L., 2007, BFI—A computer program for determining an index to base flow (ver. 4.15): Bureau of Reclamation software release, accessed July 23, 2008, at http://www.usbr.gov/pmts/hydraulics_lab/twahl/bfi/.

Woodward, D.E., Hawkins, R.H., Jiang, Ruiyun, Hjelmfelt, A.T., Van Mullem, J.A., and Quan, Q.D., 2002, Runoff curve number method-Examination of the initial abstract ratio, in Federal Interagency Hydrologic Modeling Conference, 2d, Las Vegas, Nev., 2002, Proceedings: Reston, Va., Interagency Advisory Committee on Water Data, $10 \mathrm{p}$. 
Appendixes 1-2 


\begin{tabular}{cccc}
\hline Phase One (Peterson and others, 2008) Simulation inputs (this study) & Phase Two
\end{tabular}

Software and computer code

\section{Grid-cell size}

Number of layers

Simulation periods

Streams

Streambed characteristics

\section{Recharge from precipitation}

Additional recharge from canal seepage

Additional recharge on irrigated cropland acres

Additional recharge on nonirrigated cropland acres Net irrigation pumpage

Estimated fraction of measured pumpage (used to adjust crop irrigation requirement) that returns to groundwater

\section{Groundwater Modeling System (GMS); MODFLOW-2000 Groundwater Vistas (GWV); MODFLOW-2005.}

2 miles on a side

One

Pre-1895 (one steady-state stress period), 1895 to 1940 (two stress periods), 1940 through 2005 (66 stress periods), 2006-2055 (50 stress periods)

Most streams represented in the model using the MODFLOW Stream Package (STR). Tributaries to the Niobrara represented in the model using the MODFLOW Drain Package (DRN)

Streams assigned conductance values based on size; larger streams were given larger conductance values. Some streams were adjusted if necessary to improve calibration results

Zones correspond to topographic regions. Each zone had a constant recharge value for all stress periods

Calculated from water mass balance as available. Otherwise, estimated as 43 percent of the total water diverted

Calibrated 3.5 acre-inches/acre per year

Calibrated 0.5 acre-inch/acre per year

Initially calculated as the crop irrigation requirement minus growing season effective precipitation and adjusted using measured pumping values for corn. Pumping for all crop types adjusted based on 323 measurements of pumping volume measurements for corn acres in 2005 . The majority of the measurements were collected from four counties (Antelope, Holt, Nance, and Platte)

8 percent of pumped water
1 mile on a side.

One.

Pre-1895 (one transient stress period), 1895 to 1940 (two stress periods), 1940 through 2005 (66 stress periods), 2006-2055 (50 stress periods).

All streams represented in the model using the MODFLOW Streamflow Routing Package (SFR2).

Streambed conductance was calculated separately for each stream cell using width, length, streambed hydraulic conductivity, and thickness terms. Width: determined from low-flow streamflow measurements. Length: calculated using GIS. Streambed hydraulic conductivity: assigned using aquifer hydraulic conductivity adjacent to simulated stream and then adjusted during the manual trial-and-error calibration to improve simulation results. Thickness: 1 foot.

Zones correspond to simplified watershed model regions. Recharge in each zone changed over time.

Calculated from water mass balance when available. Otherwise, estimated as 43 percent of the total water diverted.

Fixed 1.0 acre-inch/acre per year.

Fixed 0.5 acre-inch/acre per year.

Initially calculated as the crop irrigation requirement minus growing season effective precipitation and adjusted using measured pumping values. Pumping volume for acres irrigating corn, soybeans, alfalfa, and potatoes adjusted separately based on about 1,600 measurements. Pumping volume for other crops (dry beans, small grains, sorghum, sunflowers, sugarbeet) set equal to the estimated pumping volume for corn. The majority of the measurements were collected from four counties (Antelope, Holt, Nance, and Platte).

20 percent of pumped water. 
Appendix 1. Comparison of phase-one and phase-two groundwater-flow simulations, Elkhorn and Loup River Basins, Nebraska.-Continued

[MODFLOW, U.S. Geological Survey's groundwater-flow modeling software; \%, percent; ET, evapotranspiration; GIS, geographic information system]

\begin{tabular}{|c|c|c|}
\hline & Phase One (Peterson and others, 2008) & Phase Two (this study) \\
\hline & \multicolumn{2}{|c|}{ Simulation inputs-Continued } \\
\hline Evapotranspiration (ET) & $\begin{array}{l}\text { Active ET cells: determined from locations of major } \\
\text { streams, wetlands, and riparian areas published by the } \\
\text { U.S. Fish and Wildlife Service (Peterson and others, } \\
\text { 2008); Maximum ET rate: determined from lake evapo- } \\
\text { ration contours and measured ET at Odessa, Nebr. Values } \\
\text { were adjusted during calibration }\end{array}$ & $\begin{array}{l}\text { Active ET cells: determined from wetlands, open water bodies, and } \\
\text { riparian land-use categories of the CALMIT } 2005 \text { land-cover map } \\
\text { (Center for Advanced Land Management Information Technolo- } \\
\text { gies, 2007). Maximum ET rate: determined from lake evaporation } \\
\text { contours that were adjusted using measured ET at Odessa, Nebr. } \\
\text { Values were adjusted during manual trial-and-error calibration. }\end{array}$ \\
\hline Horizontal hydraulic conductivity & $\begin{array}{l}\text { Combination of values interpolated from test-hole data and } \\
\text { values assigned to } 96 \text { zones }\end{array}$ & $\begin{array}{l}\text { Values assigned to } 91 \text { zones. Initial (pre-calibration) values within } \\
\text { zones derived from test-hole data. }\end{array}$ \\
\hline Bedrock elevation & $\begin{array}{l}\text { Determined using previously published maps and test-hole } \\
\text { logs }\end{array}$ & $\begin{array}{l}\text { Adjusted elevations from phase-one simulation using data from } \\
\text { additional test holes drilled to characterize bedrock elevation in } \\
\text { areas with little or no previous information. }\end{array}$ \\
\hline \multirow[t]{2}{*}{ Specific yield } & $\begin{array}{l}\text { Interpolated from points and contours obtained from the } \\
\text { Conservation and Survey Division of the University of } \\
\text { Nebraska }\end{array}$ & $\begin{array}{l}\text { Interpolated from points and contours obtained from the Conserva- } \\
\text { tion and Survey Division of the University of Nebraska. }\end{array}$ \\
\hline & \multicolumn{2}{|c|}{ Calibration targets } \\
\hline Groundwater levels & 506 measurements used for the pre-1940 period. & 506 measurements used for the pre-1940 period. \\
\hline Groundwater-level changes & $\begin{array}{l}\text { 2,033 measurements used during the } 1940 \text { through } 2005 \\
\text { period }\end{array}$ & 3,259 measurements used during the 1940 through 2005 period. \\
\hline Base flows & $\begin{array}{l}\text { Estimated long-term average base flow at } 22 \text { streamflow- } \\
\text { gaging stations. The same targets were used for both the } \\
\text { pre-1940 and the } 1940 \text { through } 2005 \text { periods }\end{array}$ & $\begin{array}{l}1940 \text { through } 2005 \text { simulation: base-flow separation (Wahl } \\
\text { and Wahl, 2007) provided 1,435 annual base-flow targets at } \\
38 \text { streamflow-gaging stations. Low-flow streamflow measure- } \\
\text { ments provided an additional } 165 \text { targets for } 2005 \text {. Pre- } 1940 \\
\text { period: } 20 \text { base-flow targets were estimated using the annual } \\
\text { base-flow targets for the period of record. }\end{array}$ \\
\hline Calibration method & Manual trial-and-error & $\begin{array}{l}\text { Manual trial-and-error combined with automated iterative algorithm } \\
\text { (parameter estimation software). }\end{array}$ \\
\hline
\end{tabular}




\section{Appendix 2. Automated Calibration Using Parameter Estimation Software}

The Parameter Estimation software (PEST; Doherty, 2008a, 2008b) is a model-independent calibration tool and can be used with any numerical computer simulation provided that the model reads text files as input and can report simulation results in text files. Using these input and simulation results files, PEST can be instructed to adjust input parameters and compare the simulated groundwater level, groundwater-level change, and base-flow results to calibration targets. PEST uses an algorithm to systematically read the information contained in the calibration targets to determine appropriate values of input parameters. This process is commonly called "calibration," "parameter estimation," or "inverse modeling." The algorithm is sophisticated, but also naïve, so its use does not obviate the involvement and important decision-making of modelers and scientists in its implementation.

\section{The PEST Algorithm}

At the heart of PEST is a weighted-regression algorithm which, in this case, is used to estimate parameters representing hydraulic conductivity and recharge components in the groundwater-flow simulations. In essence, this algorithm is given an initial set of parameters, runs the simulation to obtain results based on the initial parameter values, and then evaluates the weighted misfit between simulated results and calibration targets. Misfit refers to the difference between simulation results collocated in time and space with a calibration target. The misfit is calculated for each target and multiplied by its corresponding weight. The weighted misfits for all targets are summed, resulting in an "objective function." The objective of the algorithm, then, is to minimize this objective function. A large value of the objective function indicates poor quality of the simulation calibration (or a large degree of misfit), whereas a small value indicates high quality.

The PEST algorithm uses the sensitivity of targets to simulation parameters to guide the selection, in sequence, of candidate parameter values used to reduce the resultant value of the objective function. The sensitivity is defined as the relative change in simulated values resulting from a small (userdefined) perturbation of the parameter value. The number of sensitivity values (used in the form of a mathematical matrix called a Jacobian matrix) is the number of targets multiplied by the number of simulation parameters. To calculate the sensitivity matrix, the simulation must be run as many times (plus one) as there are parameters. This accounts for the increase in computational and time costs incurred by adding parameters to a problem. There were 248 groundwater-model parameters in the Elkhorn-Loup Model (ELM) phase two.

The PEST algorithm is iterative in that it runs the simulation using the initial set of parameter values, evaluates the objective function, calculates the sensitivities, and from those results proposes a new candidate set of parameters. This process is repeated with the new candidate set of parameters until the value of the objective function stops decreasing, at which point the final candidate set of parameters is adopted as the best estimate of the parameter values. The concept of reducing an objective function is central to the PEST calibration process, but many factors and advanced techniques are used to facilitate its efficiency and accuracy.

\section{Considerations for Using PEST}

A successful application of the PEST calibration process is subject to several important decisions and requirements. These requirements are identified here and will be discussed in more detail throughout this section.

Parameterization.- One of the first decisions when using PEST concerns the way in which simulation parameters are defined. Parameters, in this context, are values used as simulation input that represent system properties. Hydraulic conductivity and recharge rate are examples of parameters. A modeler selects the resolution, spatial and temporal distribution, and types of parameters that are important for the intended function of the simulation and can be identified given the information that can be gained in the available calibration targets. Important considerations are computational expense and available targets. As the number of parameters increases, the computational expense of the parameter estimation process increases. The nature and amount of calibration target information also dictates the number and type of parameters that can be uniquely identified in the calibration process.

Calibration targets. - The proper use of calibration targets is fundamental for successful use of PEST, so decisions surrounding the calibration target data set are dependent upon the professional judgment of the modeler and an understanding of the hydrogeologic and hydrologic conditions at candidate sites. Calibration targets serve the dual roles of (1) defining the quality of the calibration, in part, by whether the simulation results can reproduce calibration target values, and (2) providing the information that guides the iteration inherent to PEST calibrations by providing new estimates of parameter values.

Calibration target weight. - Calibration targets in PEST are assigned weights. These weights are measures of the expected precision of the calibration targets and the amount of information they likely contain about the simulation parameters. The greater the weight assigned to a particular target relative to the weights of other targets, the more importance the PEST algorithm places on adjusting parameters such that the simulation results corresponding to that target are close to its target value. Weights, therefore, provide the opportunity to include data of varying quality in the calibration process. For example, a particular groundwater-level target may be in an area of the simulation in which details about the hydrogeology are not as well understood or where the assumptions (such as not considering vertical components of flow) 
are, for some reason, less reasonable. Such a target may be assigned a smaller weight so that the algorithm will reduce the importance of matching simulation results to that target value, particularly in relation to more heavily weighted targets. Weights are, therefore, subject to some level of subjectivity about the relative value of some targets in comparison to all the others. Using the inverse of estimated or assumed target standard deviations is a useful starting point for assigning target weights, because it approximates a measure of quality. Moreover, the standard deviation has the same units as the native measurement, so when the target value is multiplied by its weight the value is (ideally) close to unity. This avoids the disparity of units of measurement often encountered among targets. For example, base-flow values are much larger than groundwater-level values.

Model stability. - In the process of calibration, PEST stresses the simulated system by testing a wide range of parameter values. As a result, a simulation that is subject to instability, particularly that caused by dry cells in MODFLOW, may fail in the parameter estimation process; therefore, the successful modeler is careful to make the simulation as stable as possible before running PEST. Often, causes of instability can be traced to system conceptualization issues that are resolved in the process of increasing stability to the benefit of the overall model integrity. In other cases, approximations (such as a confined simulation of an unconfined system) are warranted at the early stages of the calibration process.

\section{Advantages to Using PEST in Comparison to Trial and Error}

Whereas the general conclusions regarding the advantages of PEST in comparison to manual trial-and-error estimation may extend to other available software codes, PEST was chosen as the automated calibration software because of its specific algorithmic capabilities.

Defensibility. - PEST is the industry standard modelcalibration tool for groundwater-flow models (Ginn and others, 2007). One reason for its common use is that the files associated with PEST constitute an unequivocal record documenting the design and implementation of PEST for a particular simulation. Much of the algorithm in PEST is objective, and the subjective elements are readily identifiable, can be audited, and the results of the parameter estimation can be duplicated by an independent party. This differs from manual trial-and-error calibration, in which the bookkeeping of evaluated parameter sets is a monumental task that is rarely fully documented.

Interrogation of the problem.-As mentioned above, PEST is sophisticated but naïve in the sense that, if all elements of a simulation are perfectly without error, the processes are close to linear, and the data are of good quality, PEST will yield a reasonable estimate of the parameters. However, the quality of the estimates will be contingent upon the conceptual simulation design and the quality and information content of the calibration targets. Unlike a human modeler, the PEST algorithm has no ability to abstractly adapt its view of the simulation within a rich context of other knowledge about the processes and conditions being simulated. As a result, there are many occasions when the entire PEST algorithm breaks down and either fails to provide a result or provides unreasonable intermediate results. On these occasions, the modeler must intervene by interrogating the problem to identify the causes of the algorithmic breakdown. Often, the trouble stems from an error in the way data were represented, misrepresentation of a simulated process, or another aspect of the problem that can be addressed. In this sense, PEST functions as an auditing tool, and the diagnosis and correction of conceptual or logistical errors that PEST audits reveal will lead, in the end, to a more robust, stable, and accurate simulation.

Sensitivity. - The sensitivity of simulation results to changes in parameter values is calculated for every candidate set of parameters tested in the PEST algorithm process. In addition to the important role sensitivities play in assigning weights for the PEST algorithm, valuable insights can be gained from inspecting their values throughout the calibration process. PEST can track and catalog sensitivities for further evaluation.

Quantifying uncertainty.-The PEST framework includes several utilities for the quantification of uncertainty of parameter estimates and, perhaps more importantly, of predictions made using the simulation. A useful benefit of prediction uncertainty is its potential use to identify locations for new proposed calibration targets, particularly when a simulation is intended for making a specific prediction. For example, if there is interest in downscaling the ELM to more precisely simulate effects on a small stream that cannot be accurately represented in the regional-scale model, the uncertainty of the predicted potential effect can be used to design a stream- and (or) groundwater-monitoring network at the smaller scale that will allow the maximum reduction of prediction uncertainty. For further discussion of the uses of uncertainty tools, Fienen and others (प०००) is informative.

Flexibility.-The PEST algorithm and accompanying tools have developed over many years through its use to address real-world problems in groundwater and many other applications. The result of this evolution is that the PEST framework is flexible and can accommodate a wide variety of problems and systems.

\section{Challenges and Limitations}

Flexibility.-The advantage of flexibility also may be a disadvantage to using PEST. The large array of tools and capabilities in PEST is accompanied by the need to learn and understand which tool is appropriate for a specific problem. Consequently, it is possible to obtain unreasonable results if the wrong tool is applied, or if an appropriate tool is applied with inadequate understanding. 
Model stability.-Having stated already that simulation stability is paramount to successful use of PEST, and that many causes of instability can be identified and addressed in the process of using PEST, there is no assurance that a given simulation problem can be formulated with sufficient stability to successfully run the algorithm to completion. Nonetheless, in most cases, instability problems can be overcome and, in addressing them, an underlying deficiency of the simulation or the data is alleviated in the process.

Linearization.-The theoretical basis underlying the PEST algorithm is linear mathematics. In reality, parameter estimation problems are almost never linear, so a process of iteratively using linear approximations called "linearization" is implemented. Linearization is a mature and well-accepted approach; however, theory and experience agree that if the initial estimates of parameters are too different from the optimal solution, the linearization method can perform poorly or even fail. Consequently, it is incumbent on the modeler to identify initial parameter values that are reasonably close to their optimal values.

Limitations.-Knowledgeable modelers do not expect PEST to do all the work of parameter estimation. If the simulation is poorly designed, calibration targets and parameterization are unreasonable, initial parameter values are too far from their optimal values, or the simulation is too unstable, the PEST algorithm can fail. It is incumbent on the modelers to be attentive to the design of the simulation, the assimilation of calibration target data, and the interrogation and evaluation of intermediate results throughout the calibration process. If these limitations are understood and respected, a modeler who combines expert knowledge with today's powerful parameterestimation tools can develop a successfully calibrated simulation that will be useful to decision makers.

\section{Use of PEST for the Elkhorn-Loup Model}

PEST was chosen as the support tool for calibration of the ELM simulation on the basis of an evaluation of the goals for the simulation and the considerations outlined in the previous section of this appendix. A further reason for using PEST was extensibility. As groundwater simulations have increased in size and complexity, largely because of increasing availability of computing power and the development of supporting technologies such as spreadsheets and GIS, the capabilities of PEST also have expanded, as already discussed. By adopting the PEST framework early in the process, extending the problem to use advanced capabilities of PEST is much easier than adapting a simulation after the fact. Furthermore, the powerful uncertainty-analysis tools available in PEST require many of the same steps as those required to use PEST on a simulation, so using PEST opens the opportunity to make use of these advanced tools.

The first step of any simulation is to perform manual trial-and-error calibration. The key advantages of this approach are its instructional value and its ability to produce reasonable starting values. Manual trial-and-error analysis of the calibration often identifies shortcomings in the model conceptualization, implementation, input data, or other sources. The systematic manual adjustment of sensitive parameters to achieve optimal calibration is quickly rendered inefficient, however, as the number of parameters and calibration targets grow. This motivates the conversion to PEST, but the experience gained from the manual approach continues to inform important decisions on the progression of the calibration process and the interpretation of the results.

\section{Parameter Bounds}

Two categories of calibrated parameters were used for the ELM simulation: horizontal hydraulic conductivity $\left(\mathrm{K}_{\mathrm{H}}\right)$ and recharge from precipitation. During the calibration process, these parameters were log-transformed to prevent negative values.

The bounds assigned to all parameters impose limits on parameter values assigned during the PEST calibration process. If the PEST algorithm calculates a candidate parameter value outside the bounds assigned to that parameter, the value at the bound is assigned to the parameter for the next iteration. Bounds are important at intermediate stages of the PEST algorithm progression, because instability in the algorithm may result in calculation of extreme candidate values for parameters. After parameters have been constrained by their bounds, subsequent iterations often result in reasonable parameter values. If, at the normal conclusion of an iterative PEST progression, ending parameter values deemed optimal by the algorithm are equal to their assigned bounds, a further investigation of the circumstances concerning those parameters will often reveal a problem with the simulation or data.

For calibrating the ELM simulation, bounds were assigned to $\mathrm{K}_{\mathrm{H}}$ [a lower limit of 5 feet per day (ft/d) and an upper limit of $1,000 \mathrm{ft} / \mathrm{d}$ ] and to recharge from precipitation [a lower bound of 0 inch per year (in/yr) and an upper bound of $20 \mathrm{in} / \mathrm{yr}$. Whenever parameter values reached their imposed limits in a PEST solution, it was an indication to reevaluate calibration targets, model structure, and calibration target weights. In the final versions of the parameter estimation, optimal parameter values did not stray to their bounds, indicating that weighting or targets, model structure, and use of prior information (see section "Prior Information through Regularization") had constrained the PEST algorithm such that final parameter values were reasonable.

\section{Prior Information through Regularization}

Prior information using regularization is a way to inform the PEST algorithm of a preferred condition that the modelers have deemed important enough to be a constraint on the problem. The regularization process penalizes the deviation of parameters from the preferred condition by increasing the 
objective function in proportion to the deviation of parameters from the preferred condition. In the ELM case, the preferred condition is a prior estimate of the $\mathrm{K}_{\mathrm{H}}$ parameter values, so the penalty on the objective function is calculated as a function of the difference between candidate $\mathrm{K}_{\mathrm{H}}$ parameter values and the prior $\mathrm{K}_{\mathrm{H}}$ parameter values. As a result, if the objective function decreases by a large amount at the expense of violating the preferred condition, the penalty will ensure that a more reasonable parameter set that is more consistent with the preferred condition is accepted. This avoids a problem called "overfitting," in which parameter values may stray unreasonably far from their initial values in a misguided effort (by the algorithm) to lower the objective function at all costs. The dynamics of this method of constraining the calibration problem and a detailed explanation of how to implement it are described by Hunt and others (2007), Doherty (2003), and Fienen and others (2009).

During early use of PEST to calibrate the ELM, optimized $\mathrm{K}_{\mathrm{H}}$ values strayed from their initial values to extremely large or small values. One disadvantage of using parameter zones is that zone boundaries are never known precisely. Uncertainty in the delineation of these zones can result in a situation where certain $\mathrm{K}_{\mathrm{H}}$ values unduly affect the achieved fit to certain calibration targets. Consequently, PEST may use the leverage of these $\mathrm{K}_{\mathrm{H}}$ zones to achieve unrealistically large reductions in the objective function. The prior information overcomes this by enforcing a reasonable range of values for the parameters constrained.

\section{Calibration Target Weights}

The general strategy used for calibration target weights was to use the inverse of their assumed standard deviations. This guideline is consistent with general regression theory (for example, Draper and Smith, 1966) and applications to groundwater inverse modeling (for example Hill and Tiedeman, 2007; Doherty 2008a, 2008b). It is important to consider the sources of uncertainty that contribute to the standard deviation. Basing weights solely on estimated "measurement error" implies that the only sources of uncertainty are the accuracy and precision of the tools and methods used to collect the measurement; however, additional uncertainty results from a lack of data, errors in the conceptual model, simplifications of real-world dynamics (as required in all simulations), and other sources. Embracing these sources of uncertainty is accompanied by an acknowledgement that we may be estimating the standard deviation of the targets without full knowledge of all error sources. This means the assignment of weights involves a subjective evaluation of error, informed by expert knowledge of the dynamics of the system, the particular model implementation and design, and the nature and quality of the calibration targets.

Pre-1940 groundwater-level targets.-All pre-1940 groundwater-level targets were assigned a weight of 0.1 , corresponding to an estimated standard deviation of 10 feet (ft). This value reflects the assumed uncertainty of groundwaterlevel measurements in the pre-1940 period. The total uncertainty is not only a result of measurement uncertainty, but also uncertainty about the precise time of the measurement, the assumption of unchanging conditions throughout the pre-1940 period, uncertainty of the exact spatial location, and the imprecision of spatial interpolation of measured levels, required by the sparseness of data and the large size of simulation grid cells. The other factor affecting this choice of weight value was the need to balance the contribution of each target type to the objective function. If this weight was greater, the fit to groundwater-level targets would have been closer, but at the expense of acceptable fits to other targets.

1945 through 2005 groundwater-level change targets.-Reasoning similar to that guiding the assignment of groundwater-level target weights was applied to the decadal groundwater-level-change targets for the groundwater development period. Groundwater-level-change targets located near streams are not expected to be simulated with high precision in a regional model. Consequently, weights for groundwaterlevel-change targets within 1 mile of any stream were set equal to zero. In this way, the target does not get considered in the objective function, but the target fit is still included in the report by PEST to enable an external post-audit to qualitatively assess calibration quality. The remaining groundwaterlevel-change targets were assigned a weight value of 0.198 , corresponding to a standard deviation of $5.05 \mathrm{ft}$. This level of uncertainty is justified for the same reasons as used for weights assigned to the groundwater-level targets-it takes into consideration the decadal time scale for which fits to groundwater-level-change targets were evaluated. However, the uncertainty is less than for the groundwater-level targets, in part because the groundwater-level-change targets are calculated as the difference between groundwater levels at the same location but at different times. As a result, the uncertainty contributions related to locational precision and spatial interpolation are likely to cancel in the subtraction operation. The imprecision in recorded time of measurements, combined with the need to balance the contribution of groundwaterlevel-change targets to the overall objective function, also were factors affecting final weights assigned to the groundwater-level-change targets.

1940 through 2005 base-flow targets. - Each 1940 through 2005 period base-flow target was assigned a weight based on the reciprocal of the standard deviation of its annual values for the period of the simulation. One exception to this protocol was for the base-flow targets estimated from only a single low-flow measurement in 2006. It is not possible to calculate a standard deviation from a single measurement, so these targets were assigned the mean weight of all the other development-period base-flow targets. Base-flow targets associated with streamflow-gaging stations that were downstream from canal diversions were assigned weights equal to one-half the reciprocal of the standard deviation of their annual values for the period of the simulation. Also, base-flow target weights for three streamflow-gaging stations on the Dismal and Middle Loup Rivers (U.S. Geological Survey sites 06775500, 06775900, and 06776500) were increased by one order of magnitude from the reciprocal of the standard deviation of 
their annual values. These three sites were upstream from canal diversions, and their increased weights further minimized the effect of canal diversions on base-flow targets, and thereby on the calibrated simulation results.
Pre-1940 base-flow targets.-The pre-1940 period baseflow calibration targets were collocated with 1940 through 2005 period base-flow targets and assigned the same weight as their 1940 through 2005 period counterparts. 
Publishing support provided by: Rolla Publishing Service Center

For more information concerning this publication, contact: Director, USGS Nebraska Water Science Center 5231 South 19th Street

Lincoln, NE 68512-1271

(402) 328-4100

Or visit the Nebraska Water Science Center Web site at: http://ne.water.usgs.gov 
